Supporting information for

\title{
Aryl Sulfonamide Inhibits Entry and Replication of Diverse Influenza Viruses via the Hemagglutinin Protein
}

Kris White ${ }^{1,2,7}$, Matthew Esparza ${ }^{3,7}$, Jue Liang ${ }^{4}$, Prasanna Bhat ${ }^{3}$, Jacinth Naidoo ${ }^{4}$, Briana L. McGovern ${ }^{1,2}$, Michael A. P. Williams ${ }^{1,2}$, Busola R. Alabi ${ }^{3}$, Jerry Shay ${ }^{3}$, Hanspeter Niederstrasser ${ }^{4}$, Bruce Posner ${ }^{4}$, Adolfo García-Sastre ${ }^{1,2,5,6}$, Joseph Ready ${ }^{4}$, and Beatriz M. A. Fontoura ${ }^{3 *}$

${ }^{1}$ Department of Microbiology, Icahn School of Medicine at Mount Sinai, New York, NY 10029, USA

${ }^{2}$ Global Health and Emerging Pathogens Institute, Icahn School of Medicine at Mount Sinai, New York, NY 10029, USA

${ }^{3}$ Department of Cell Biology, University of Texas Southwestern Medical Center, Dallas, TX 75390, USA

${ }^{4}$ Department of Biochemistry, University of Texas Southwestern Medical Center, Dallas, TX 75390, USA

${ }^{5}$ Department of Medicine, Division of Infectious Diseases, Icahn School of Medicine at Mount Sinai, New York, NY 10029, USA

${ }^{6}$ The Tisch Cancer Institute, Icahn School of Medicine at Mount Sinai, New York, NY 10029, USA

7 These authors contributed equally to this work.

*Corresponding author: Beatriz M. A. Fontoura, Department of Cell Biology, University of Texas Southwestern Medical Center, 6000 Harry Hines Blvd., room number NL7.138A, Dallas, TX 75390-9039, USA, phone: (214) 648-4207; e-mail: beatriz.fontoura@utsouthwestern.edu

\section{Supporting information available:}

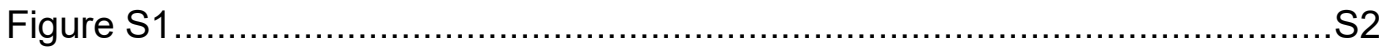

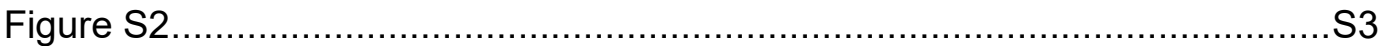

NMR Spectra for new compounds ........................................... S4-S56 

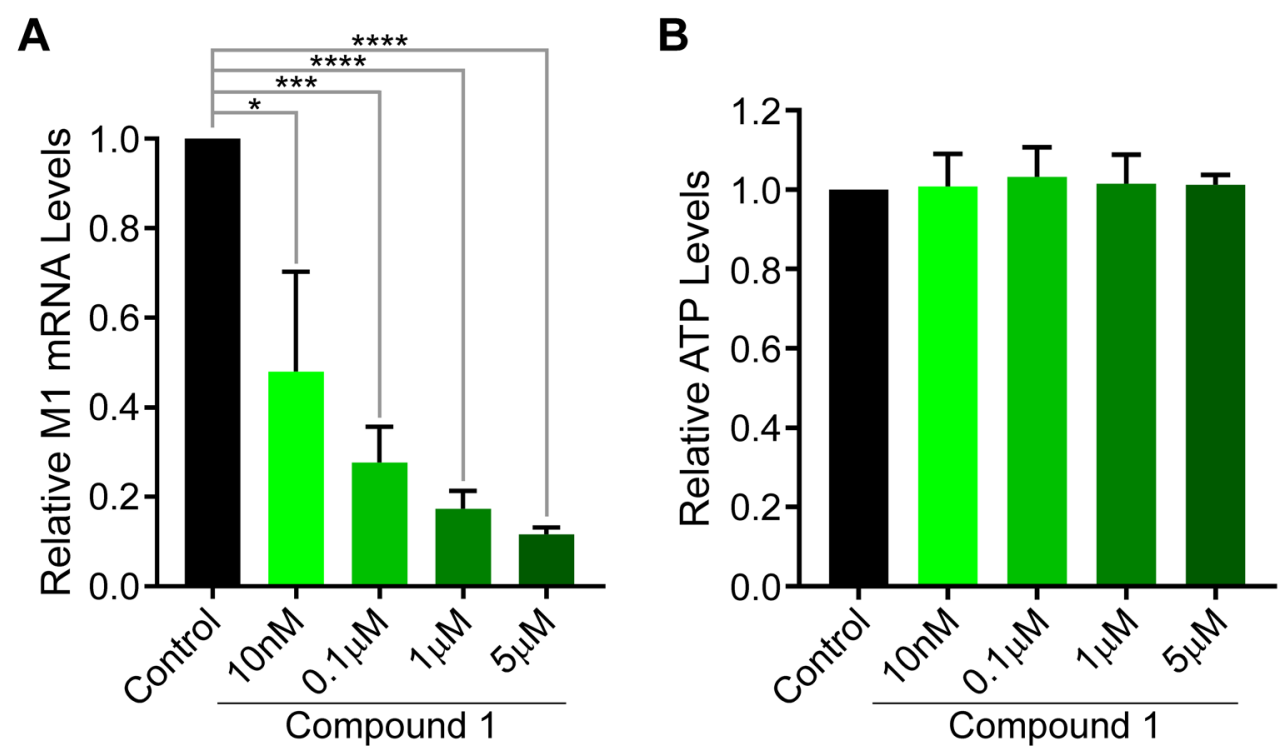

Figure S1. Compound 1 reduces influenza virus mRNA levels in human lung primary cells. (A) DMSO (0.1\%) or compound 1 (at the depicted concentrations) were added to primary human bronchial epithelial cells $1 \mathrm{~h}$ before infection with WSN at MOI 1. Infection was performed for 24 $\mathrm{h}$ in the presence or absence of compound. Purified RNA from total cell lysates were collected and subjected to qPCR to measure viral M mRNA levels. (B) DMSO (0.1\%) or compound 1 (at the depicted concentrations) were added to primary human bronchial epithelial cells for $25 \mathrm{~h}$. ATP levels were measured using CellTiter-Glo to assess cell viability. At least three independent experiments were performed for all datasets. Graphs are mean $+/-\mathrm{SD}$. ${ }^{*} p<0.05,{ }^{* *} p<0.01$, ${ }^{* * *} p<0.001,{ }^{* * * *} p<0.0001$ 

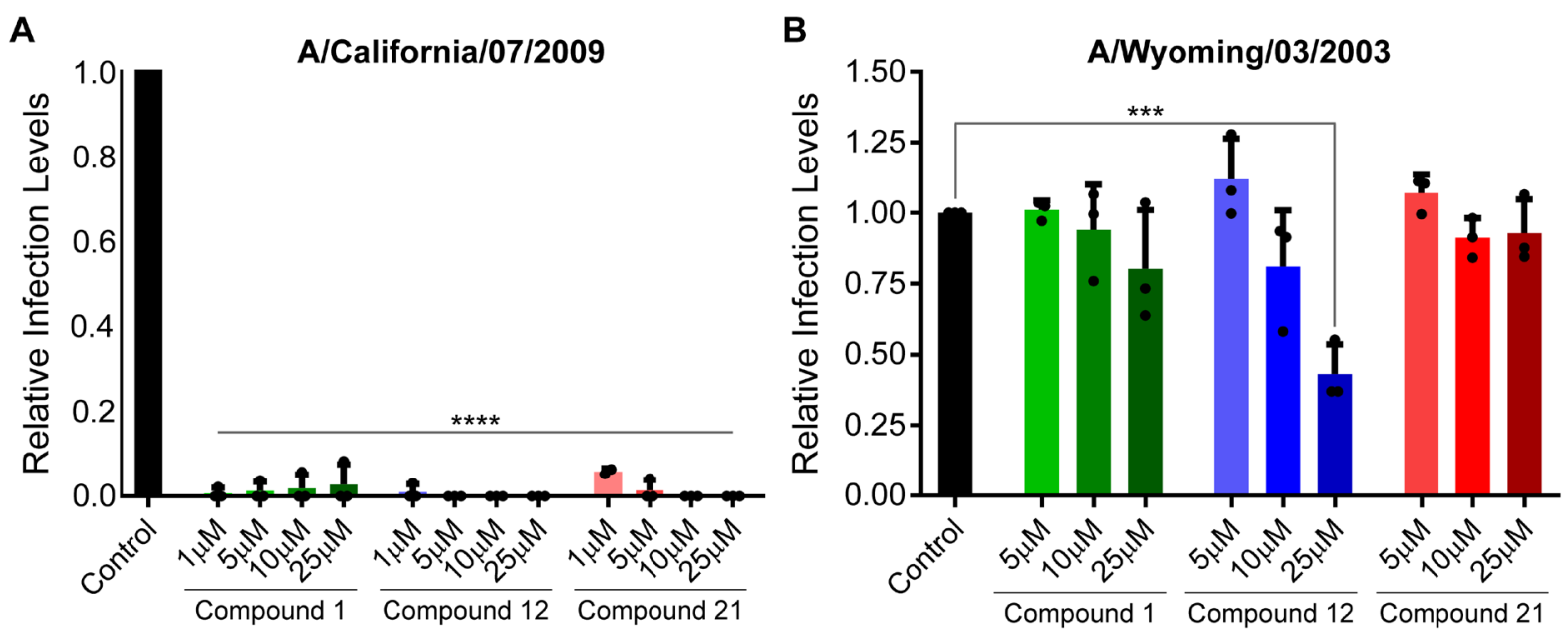

C

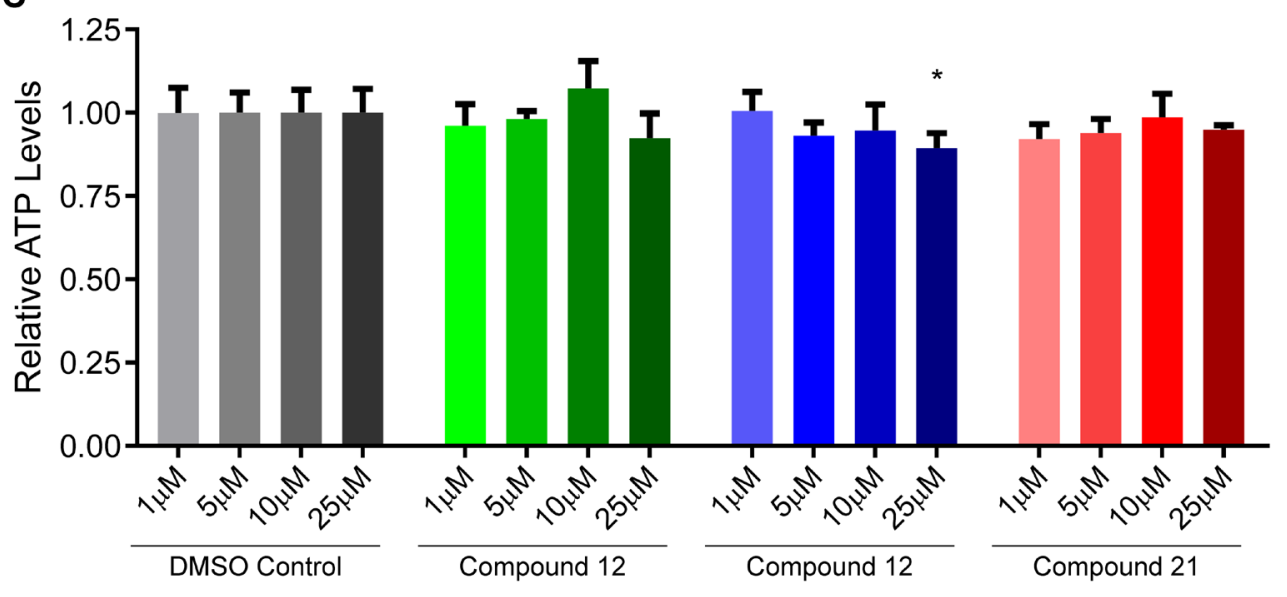

Figure S2. Effects of compounds 1, 12, or 21 on cells infected with A/California/07/2009 (H1N1) or A/Wyoming/3/03 (H3N2). A549 cells were incubated with compounds 1, 12, or 21 at the depicted concentrations for $1 \mathrm{~h}$ and were then infected with $A / C a l i f o r n i a / 07 / 2009$ (A) or A/Wyoming/3/03 (B) at MOI 1 in the absence or presence of compounds. DMSO treated cells were considered as control. Cells were fixed $8 \mathrm{~h}$ post-infection and subjected to smRNA-FISH using probes against IAV M mRNA. Percentage of infected cells was then calculated. At least 225 cells per condition were scored. Each experiment was performed in triplicate. $t$-test was used to calculate $p$ values. $n s=p>0.05,{ }^{*} p \leq 0.05,{ }^{* *} p \leq 0.01,{ }^{* * *} p \leq 0.001$. (C) A549 cells were treated with $25 \mu \mathrm{M}$ of compounds 1, 12, and 21 for $9 \mathrm{~h}$. ATP levels were measured as surrogate for cell viability. Each experiment was performed in triplicate. $t$-test was used to calculate $p$ values. $n s=p>$ $0.05,{ }^{*} \mathrm{p} \leq 0.05$ 


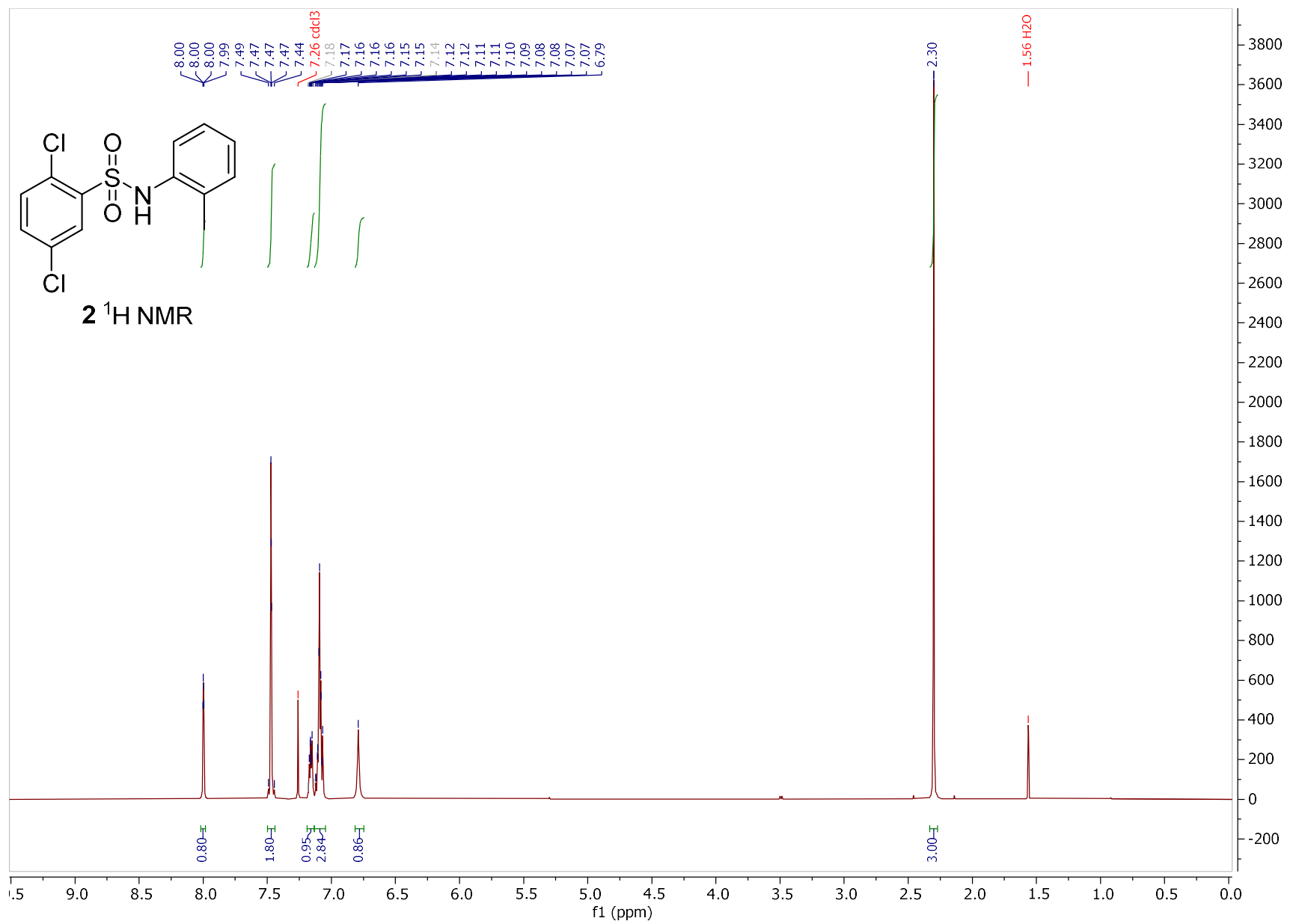



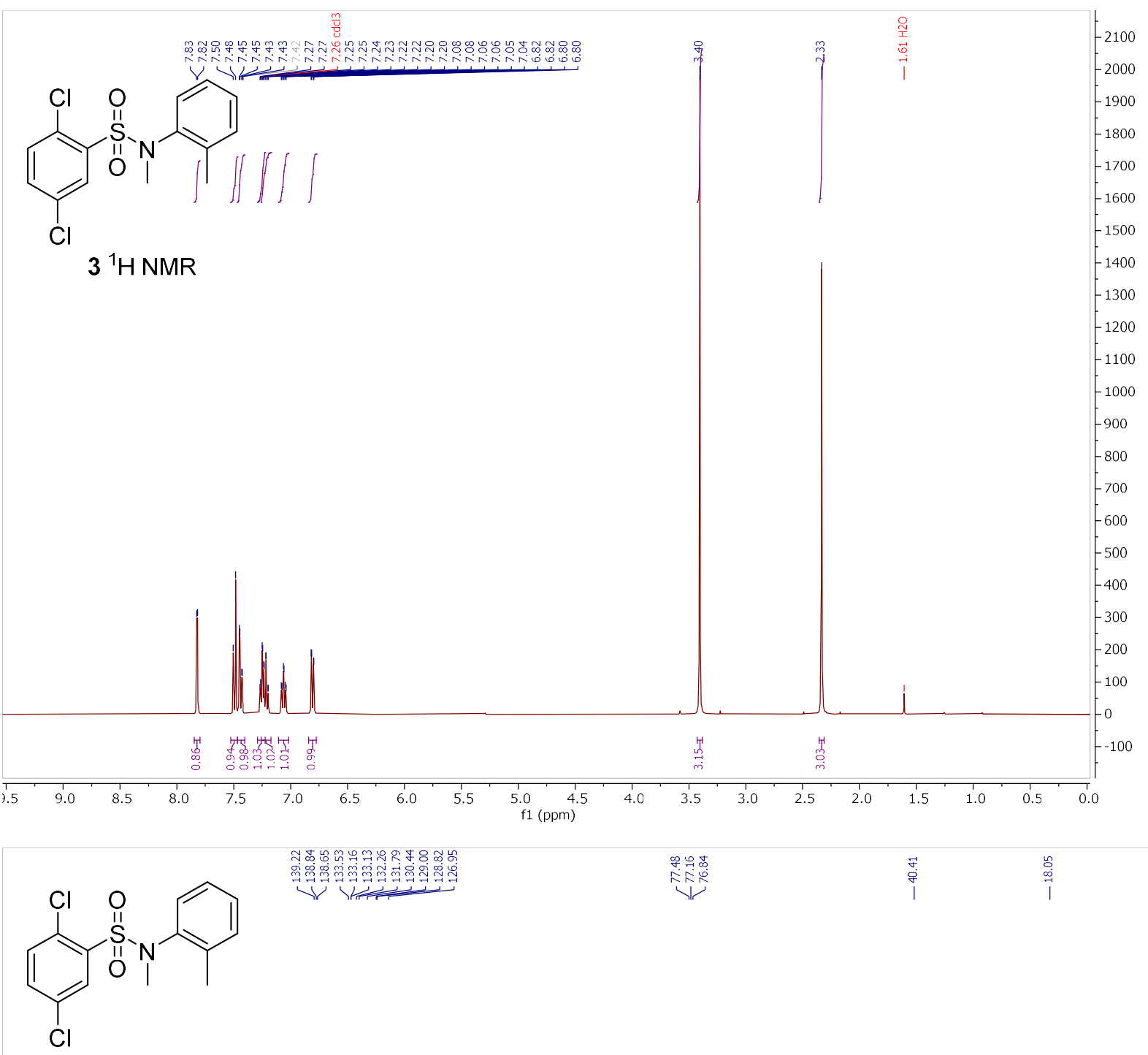

$3{ }^{13} \mathrm{C}$ NMR

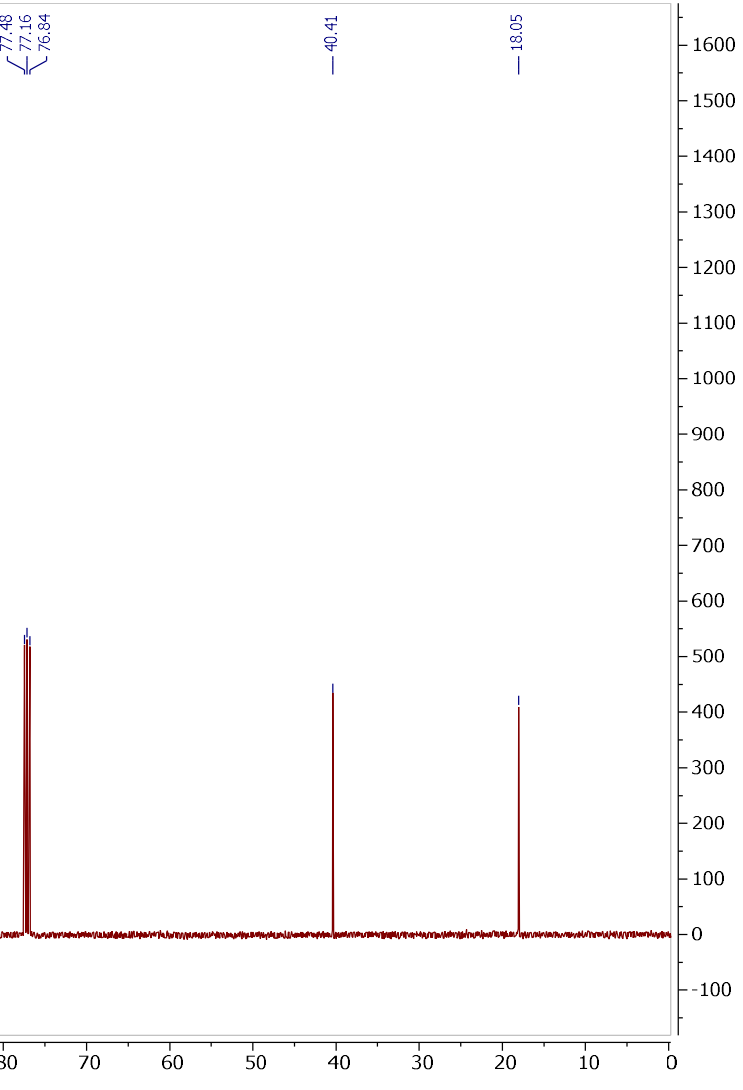




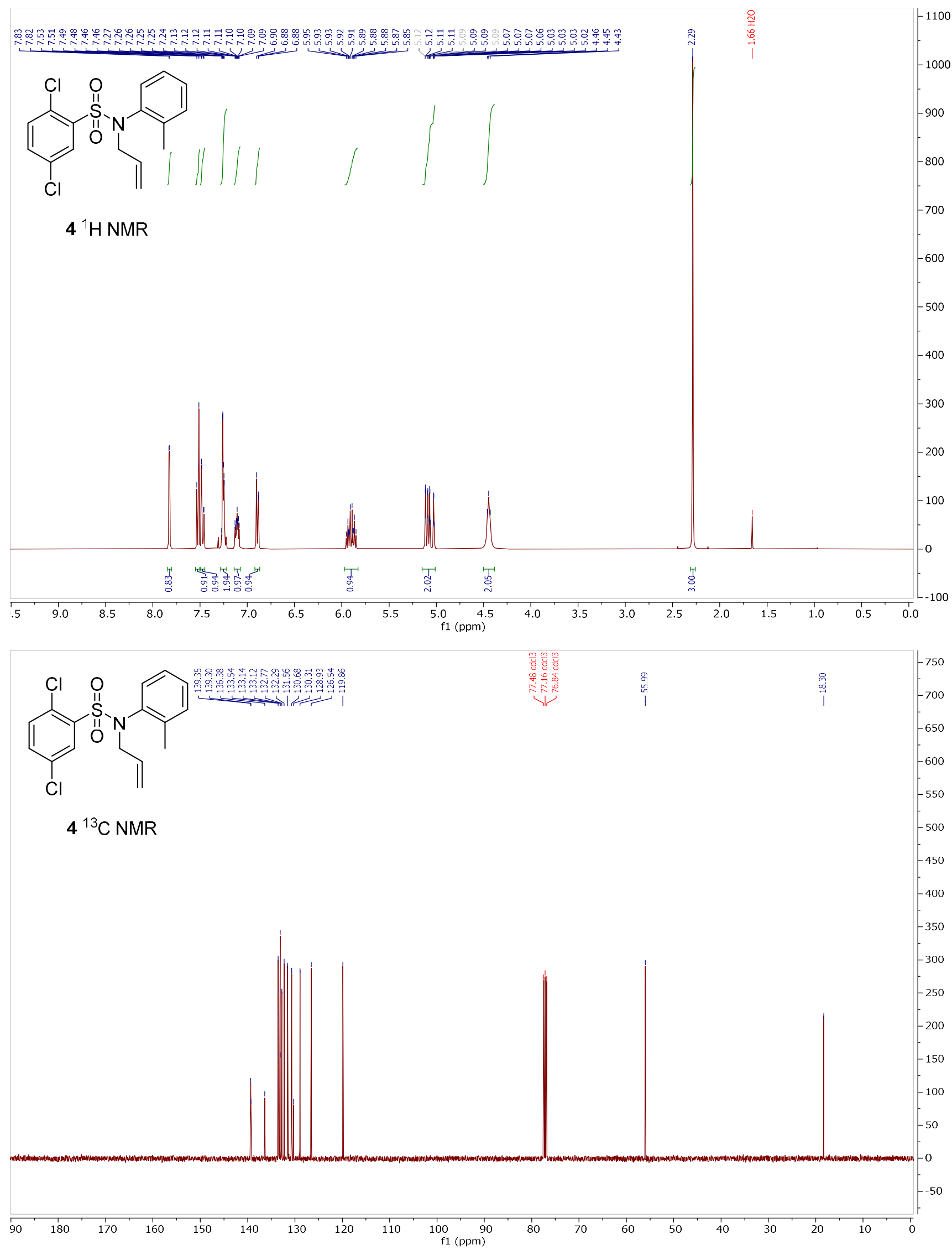



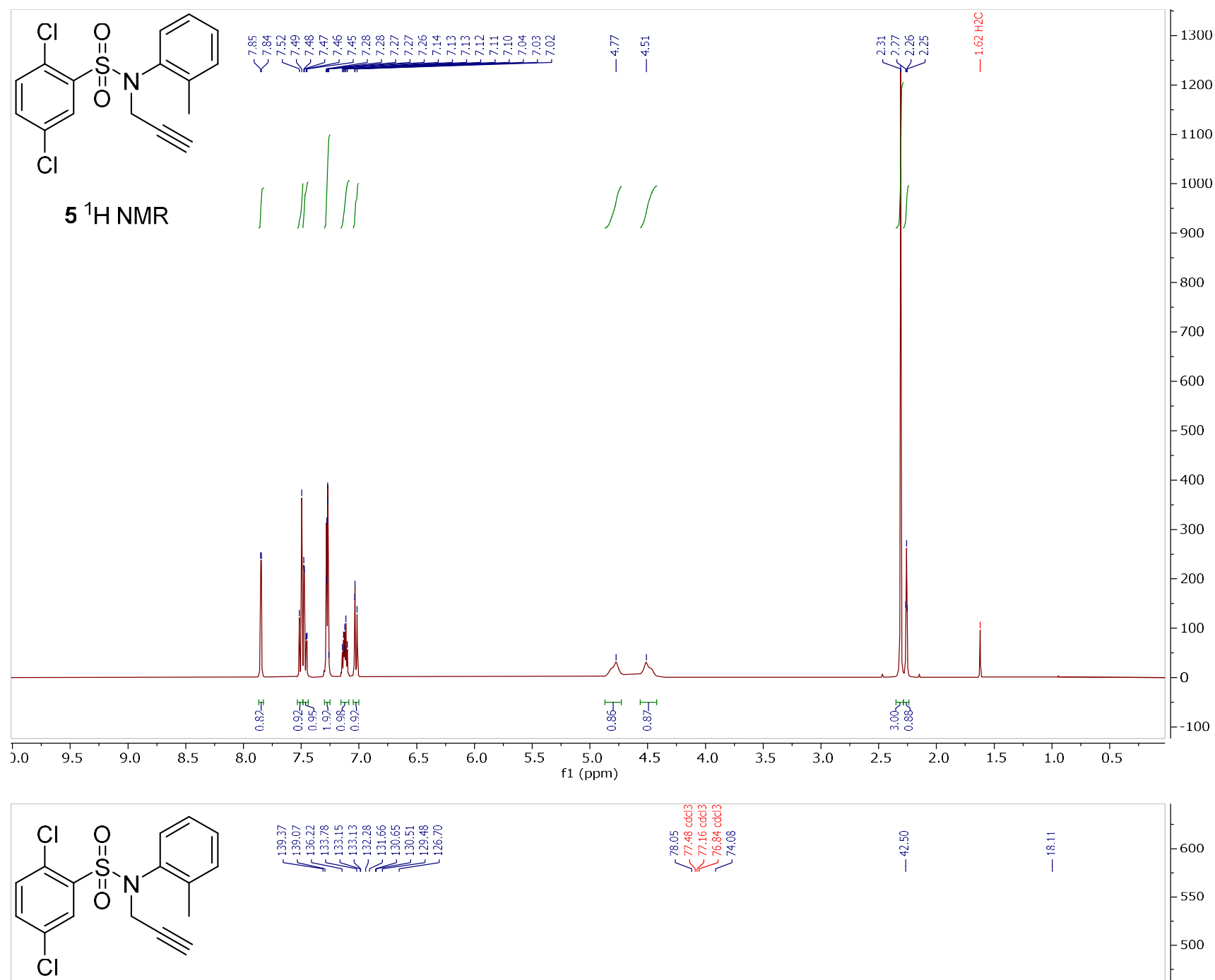

$5{ }^{13} \mathrm{C}$ NMR

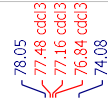

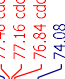

(2)
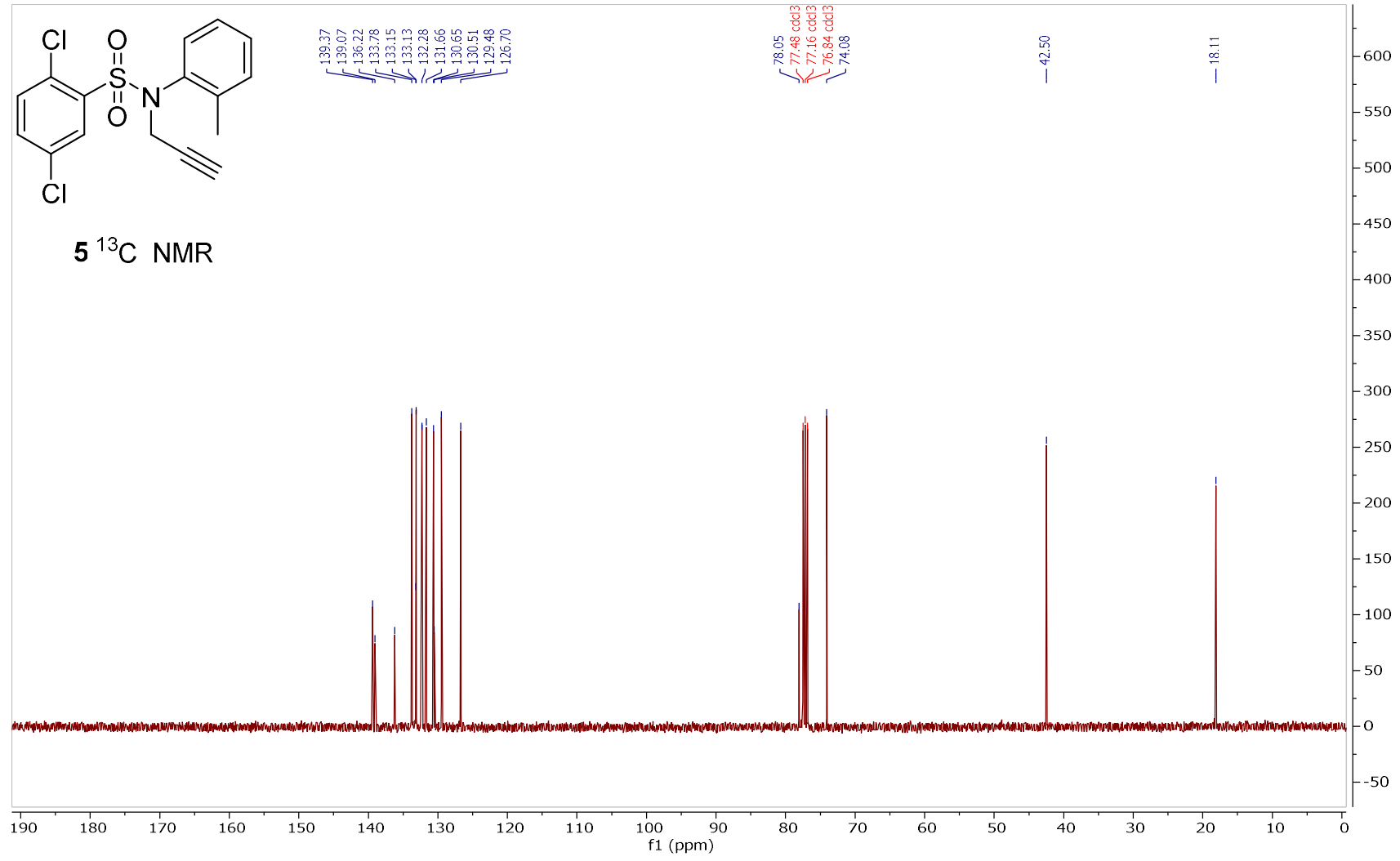


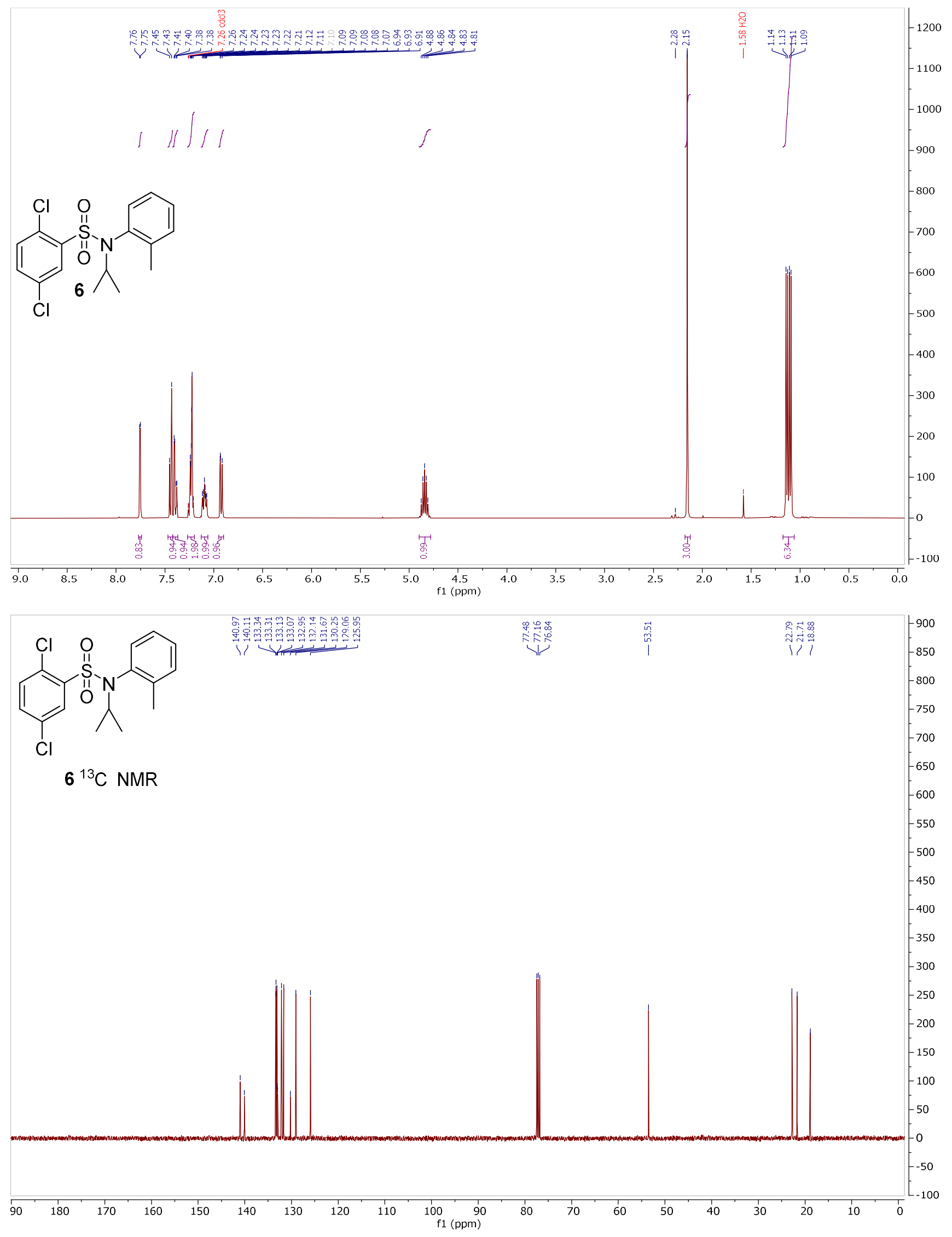




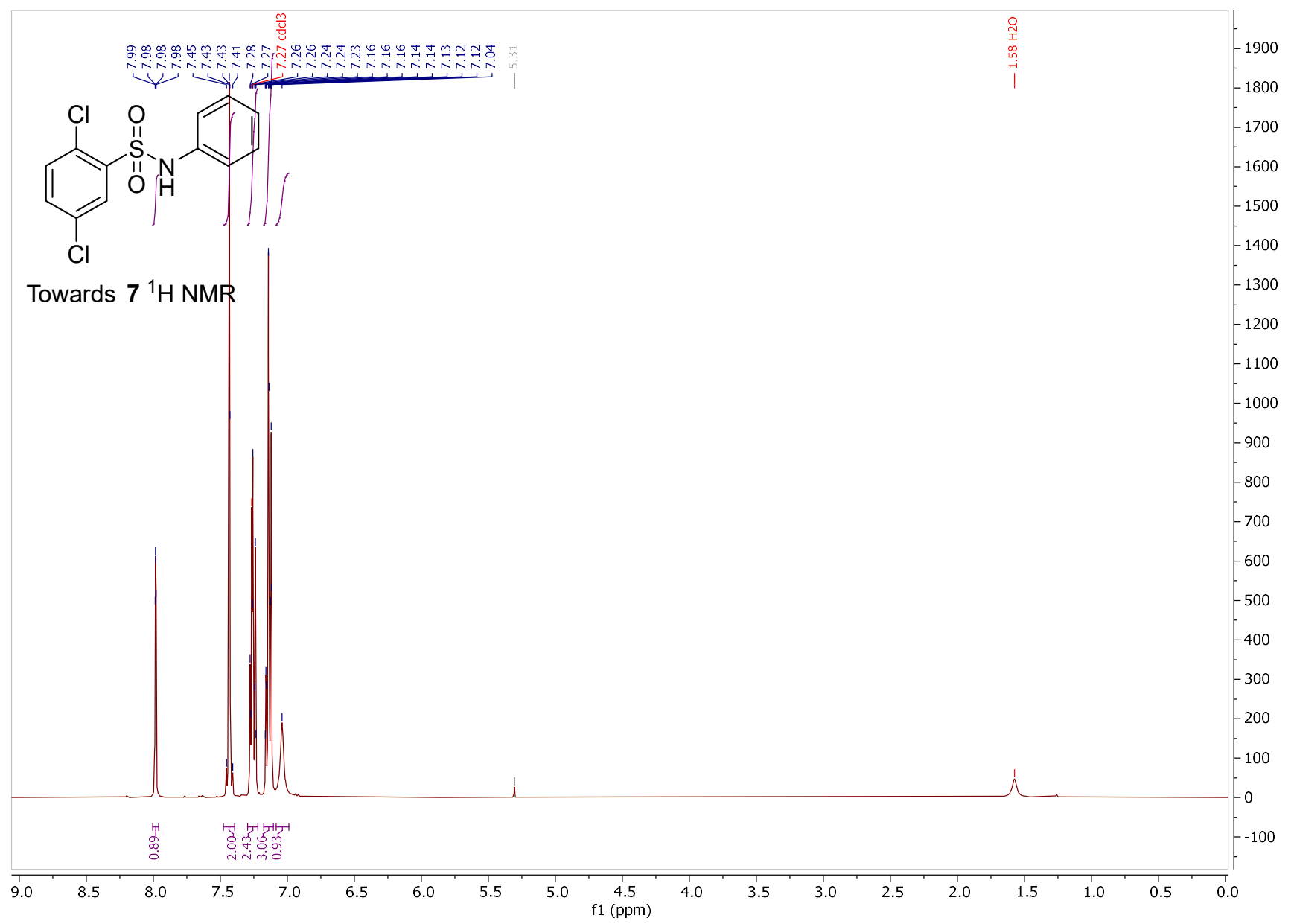



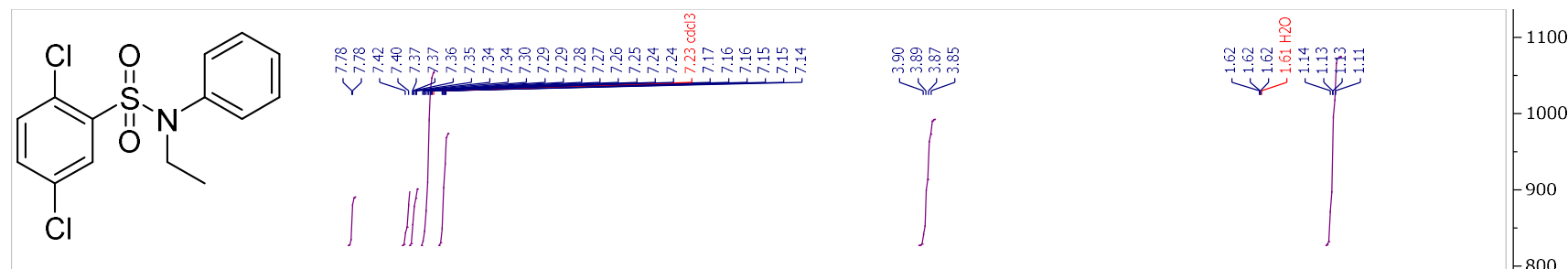

$7{ }^{1} \mathrm{H}$ NMR

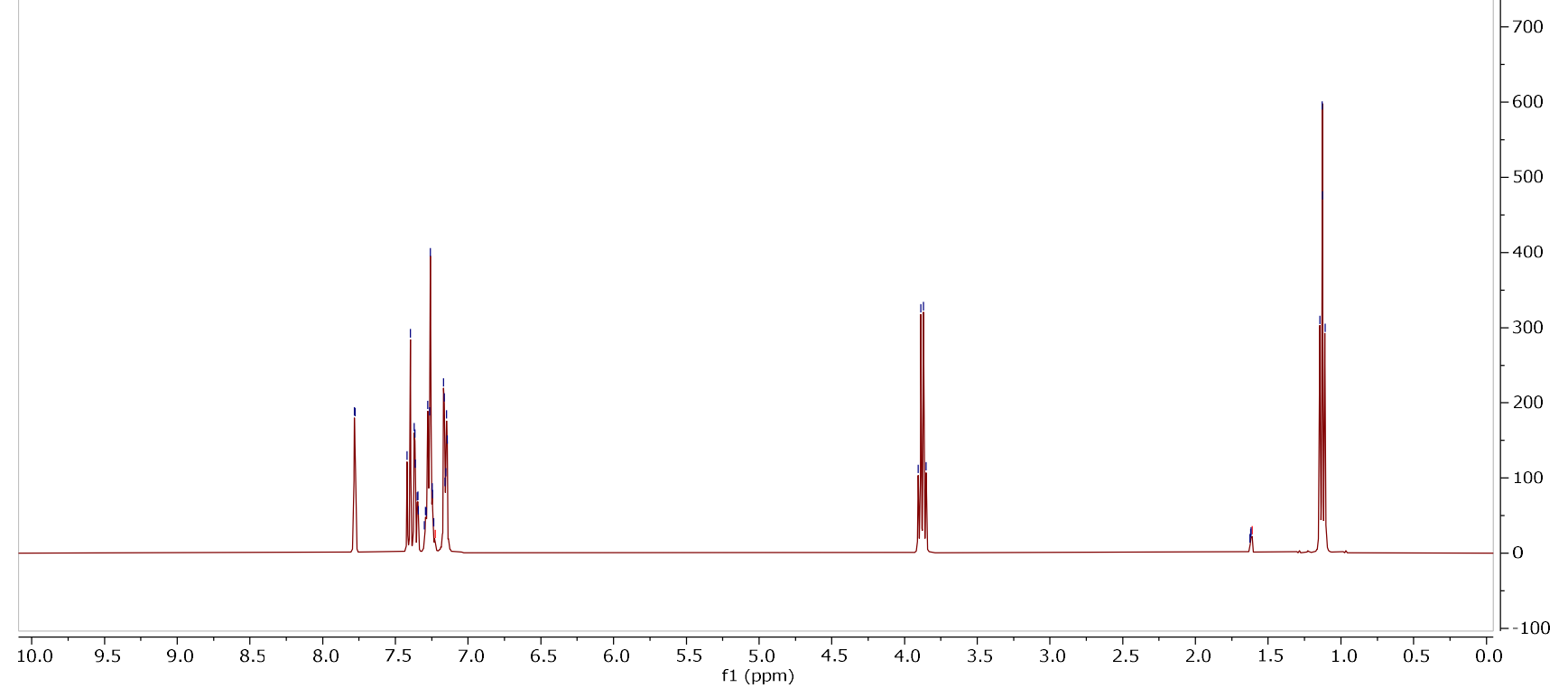<smiles>CCN(c1ccccc1)S(=O)(=O)c1cc(Cl)ccc1Cl</smiles>
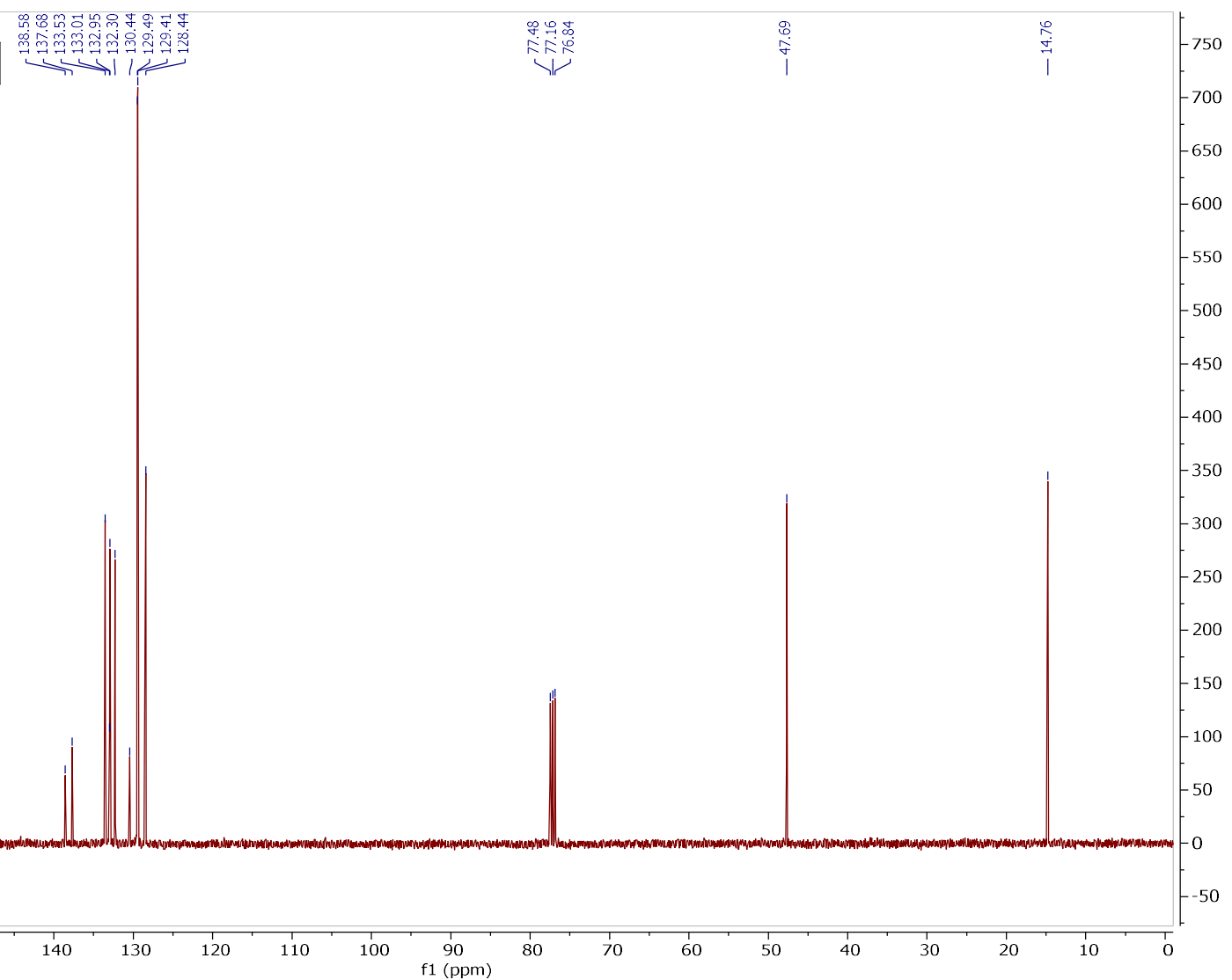

$7{ }^{13} \mathrm{C}$ NMR 


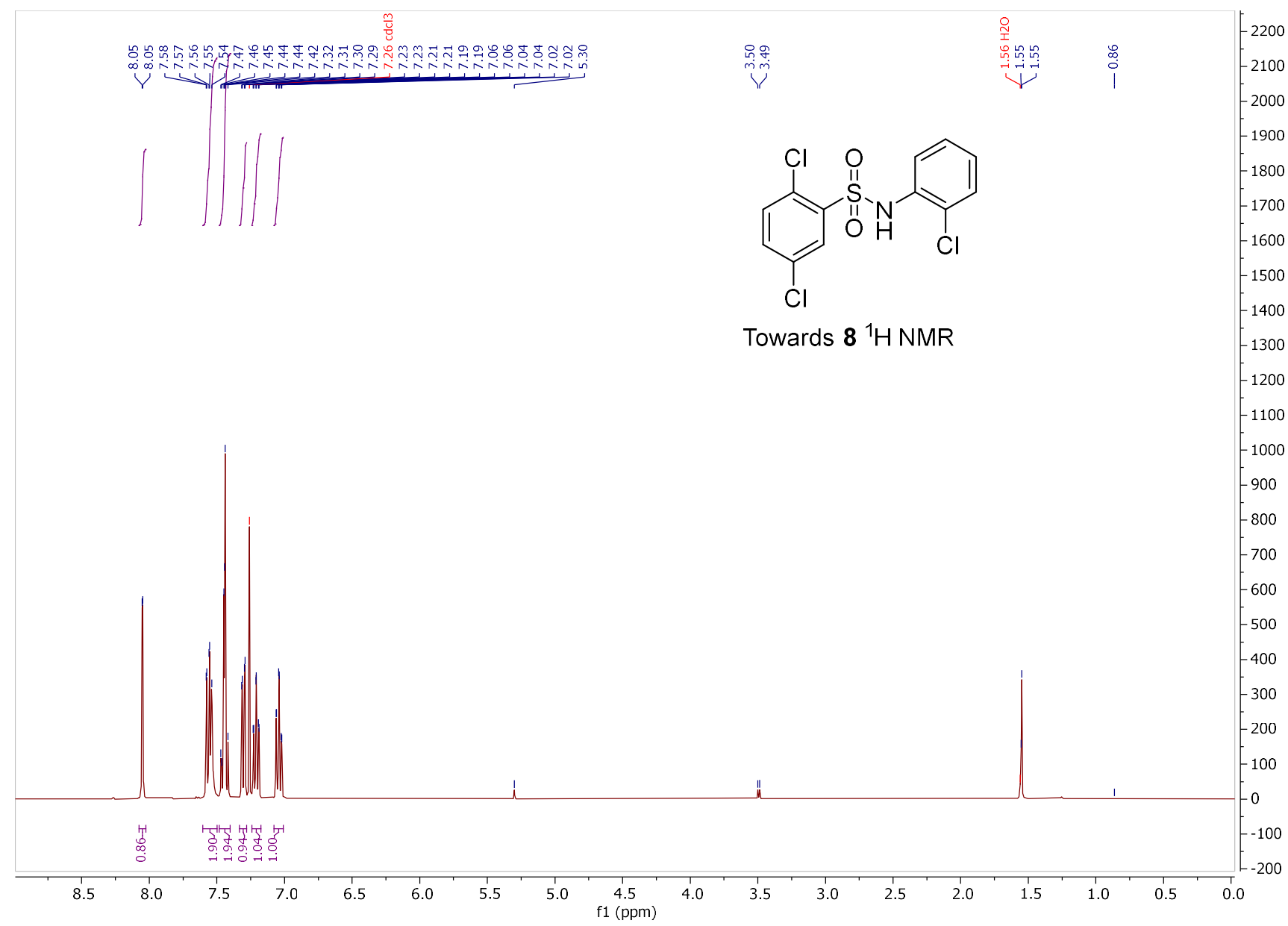



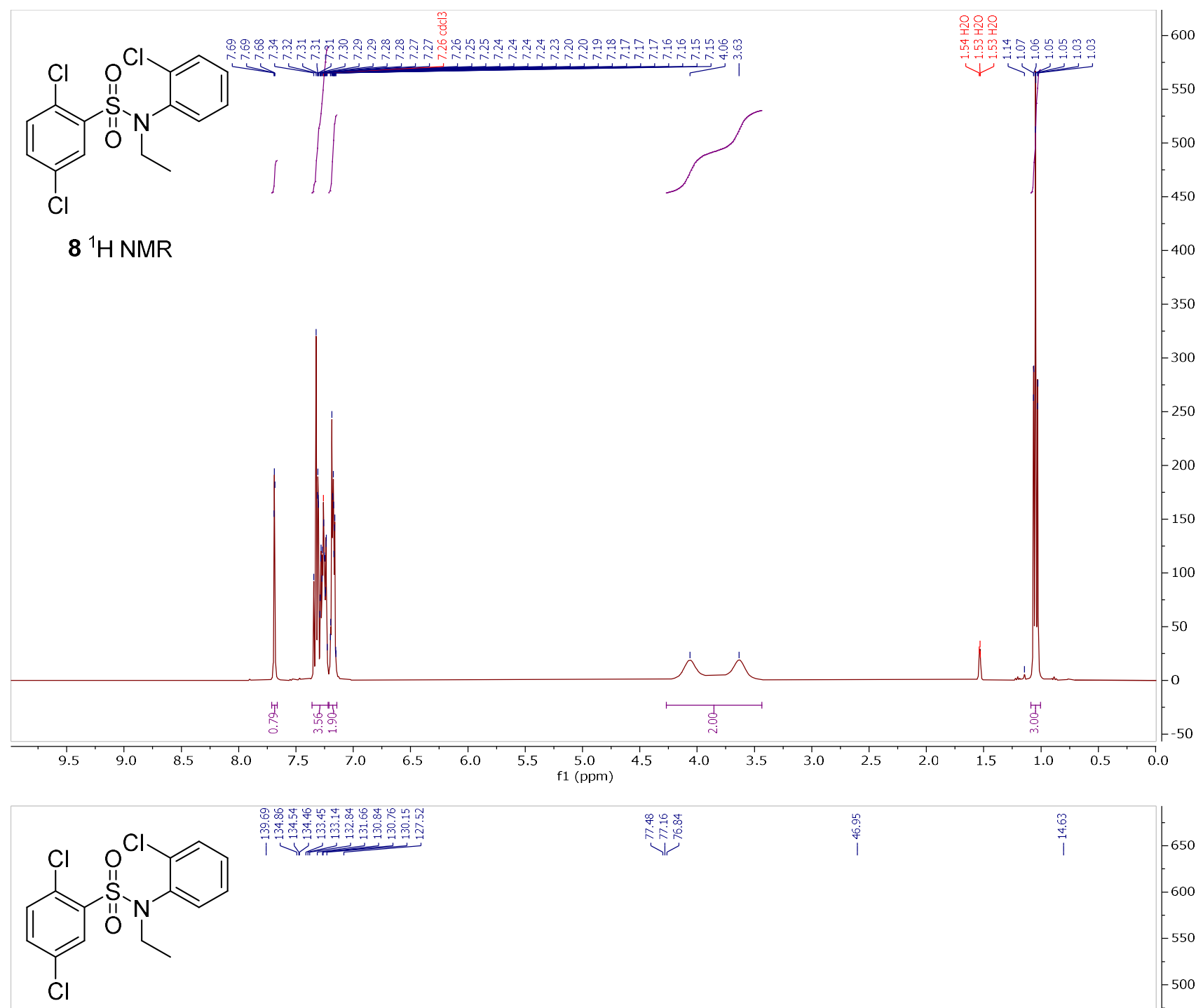

$8{ }^{13} \mathrm{C}$ NMR

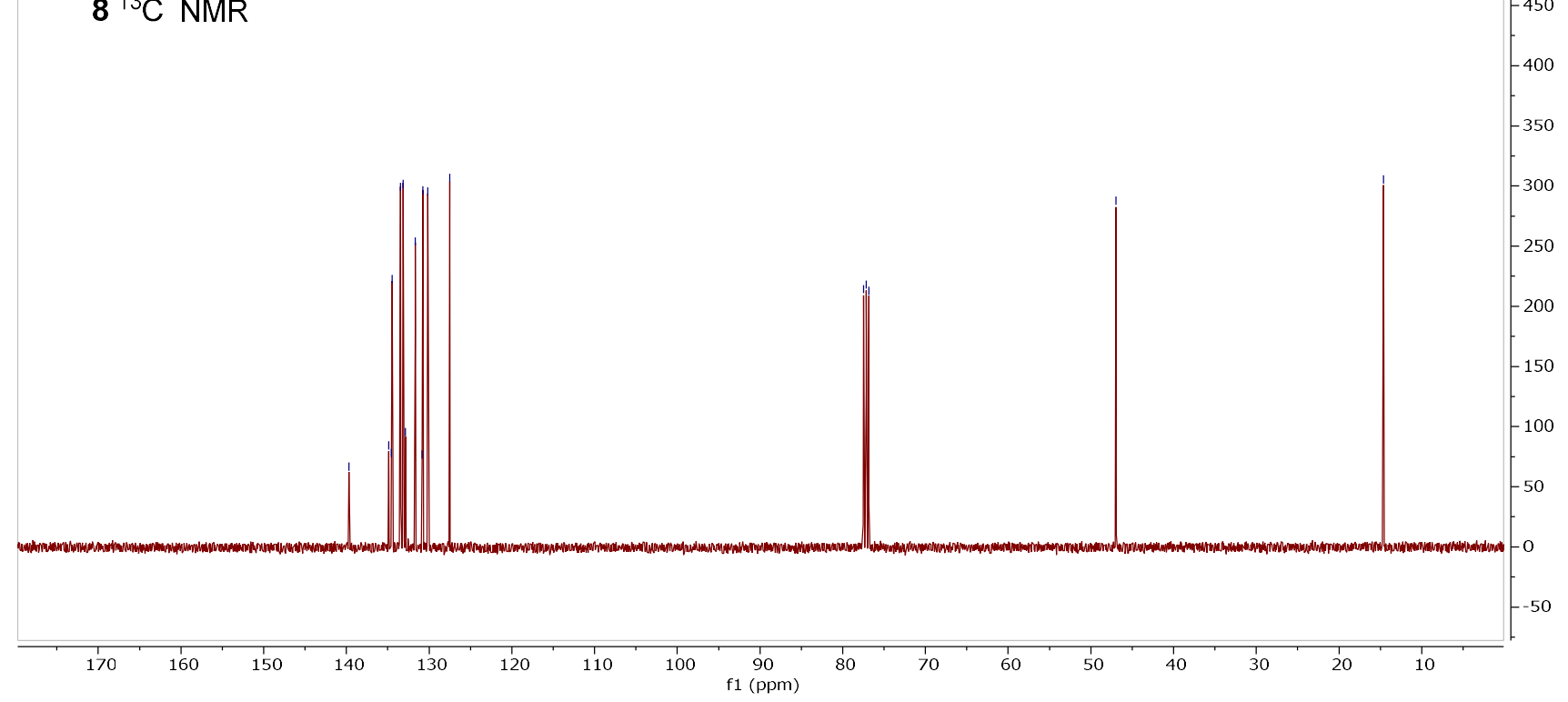




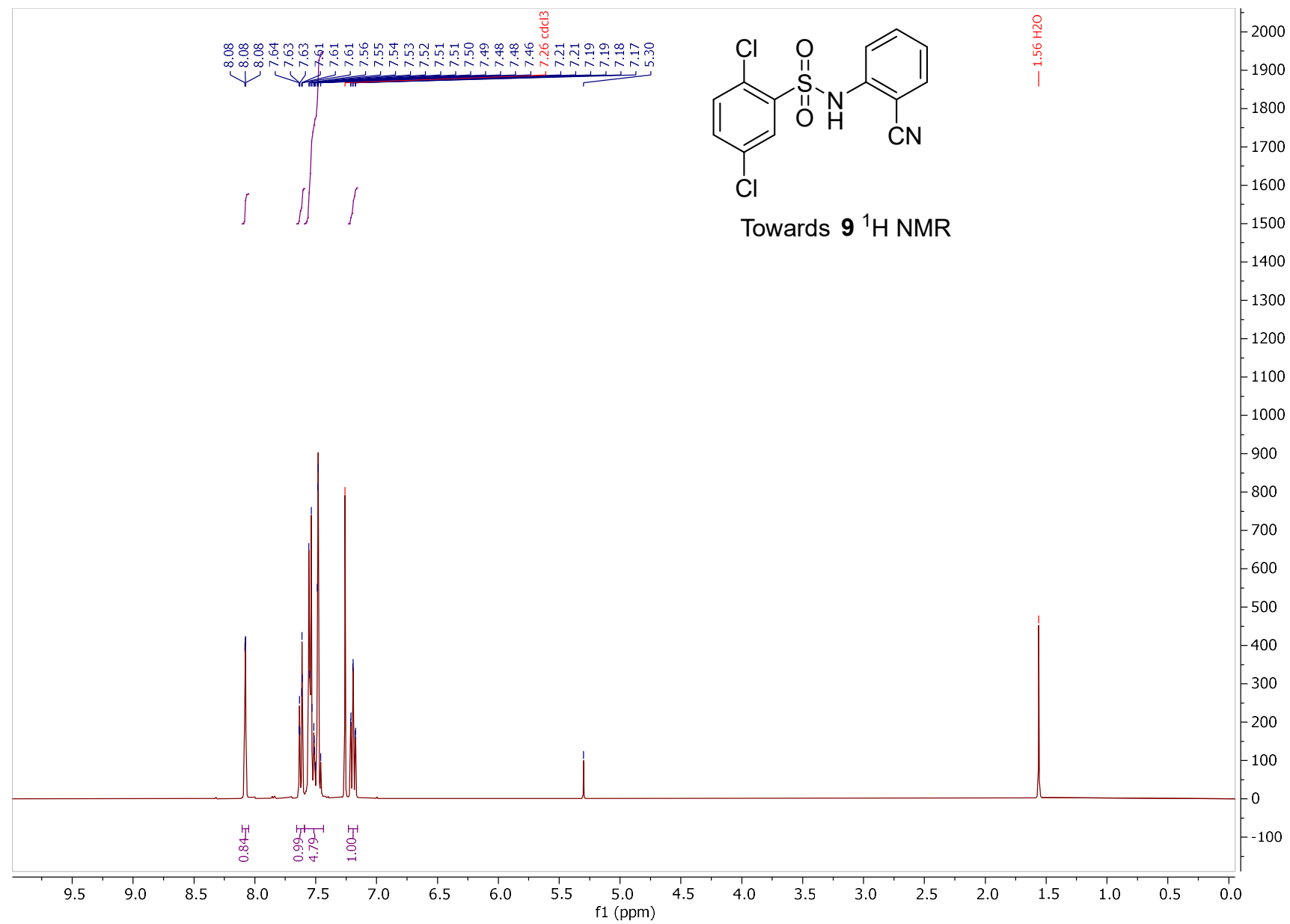



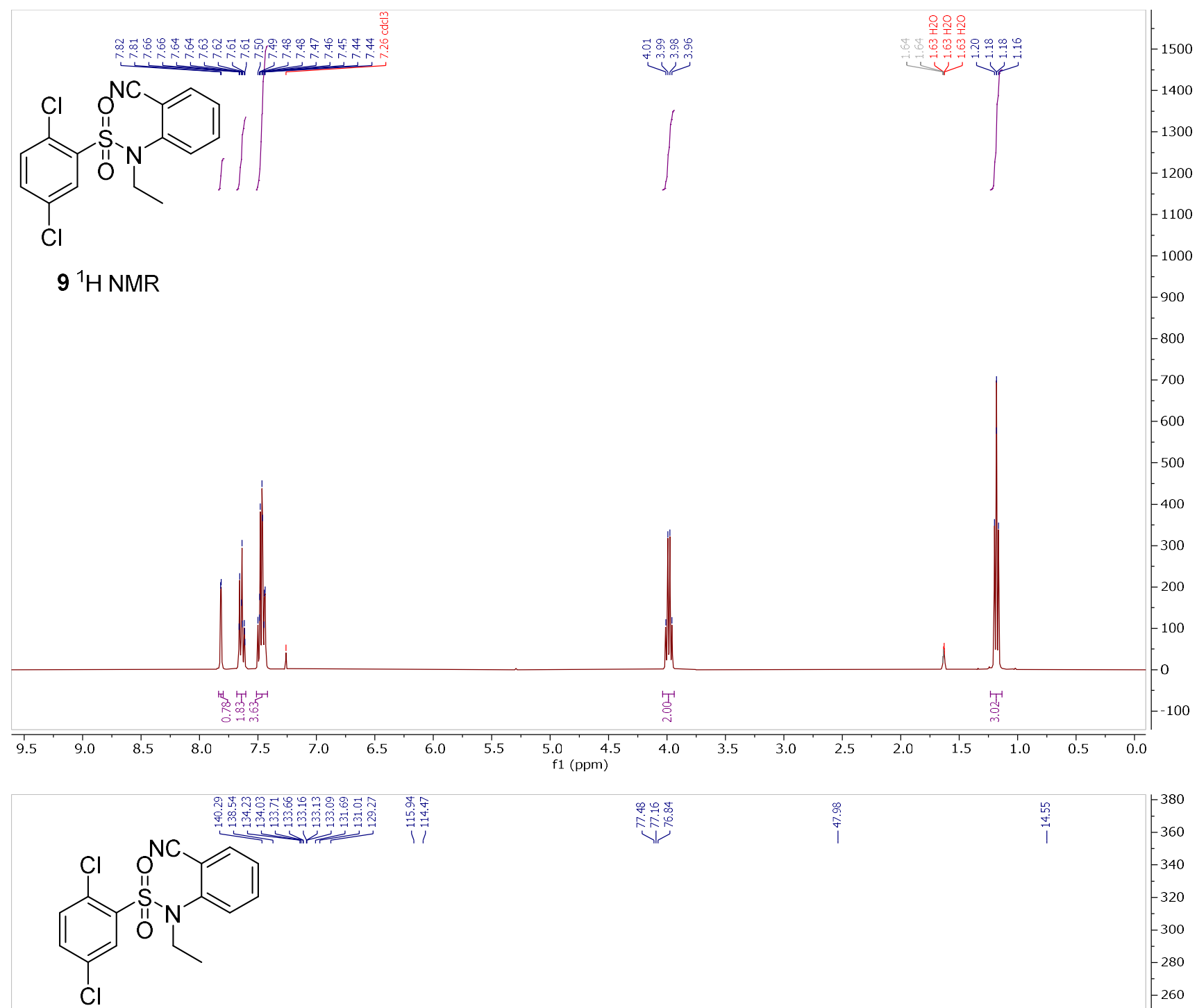

$9{ }^{13} \mathrm{C}$ NMR
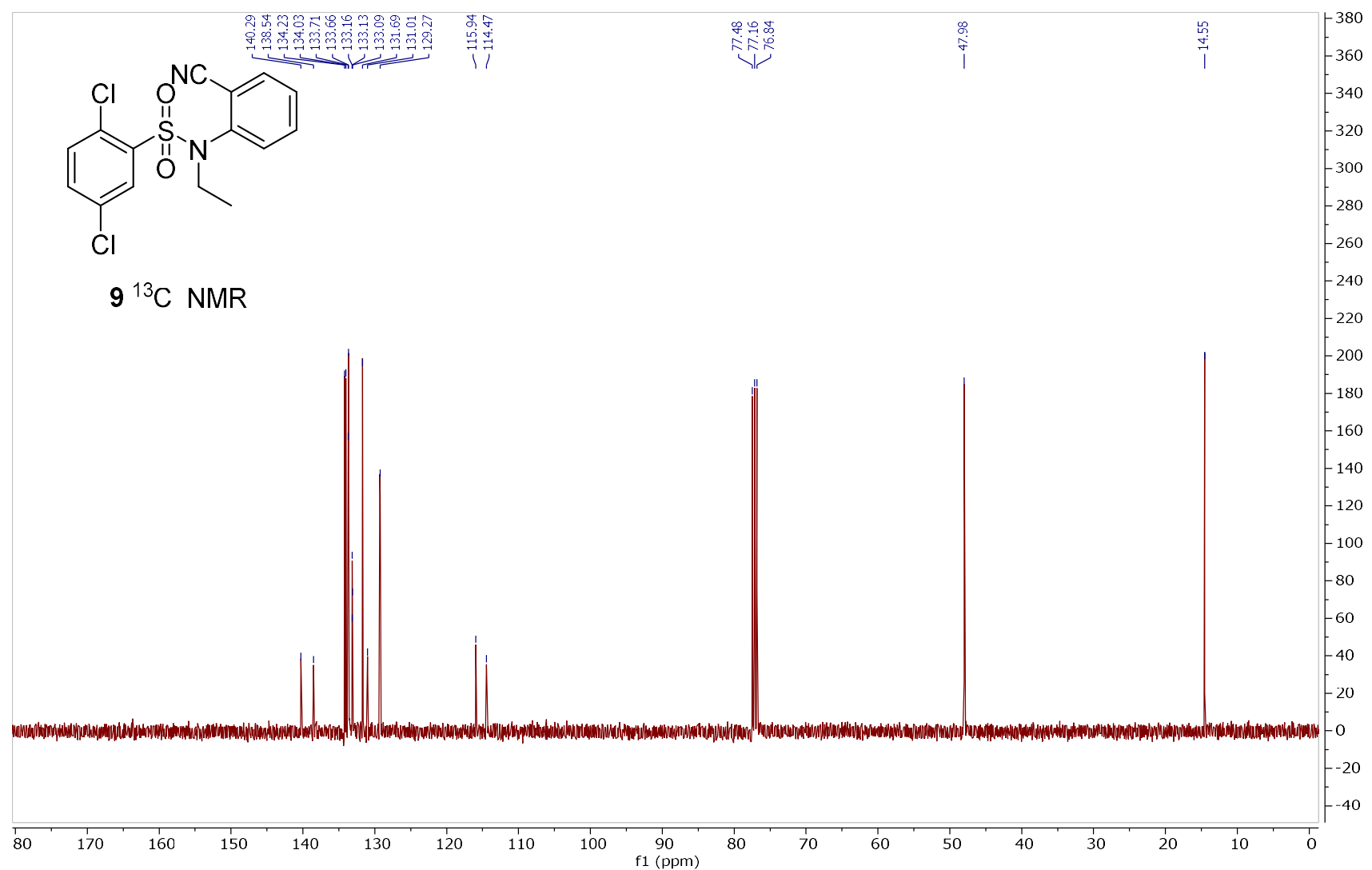

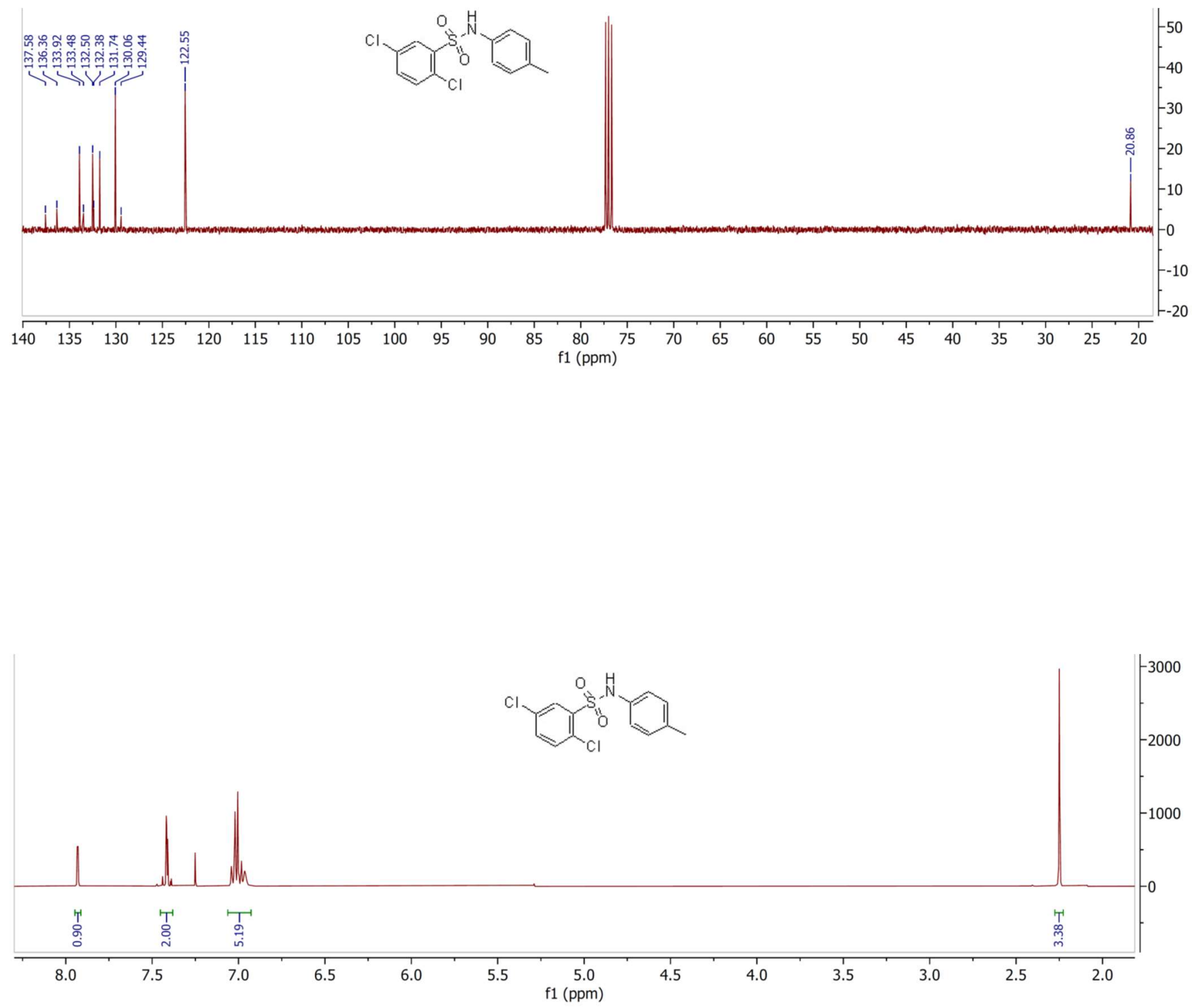

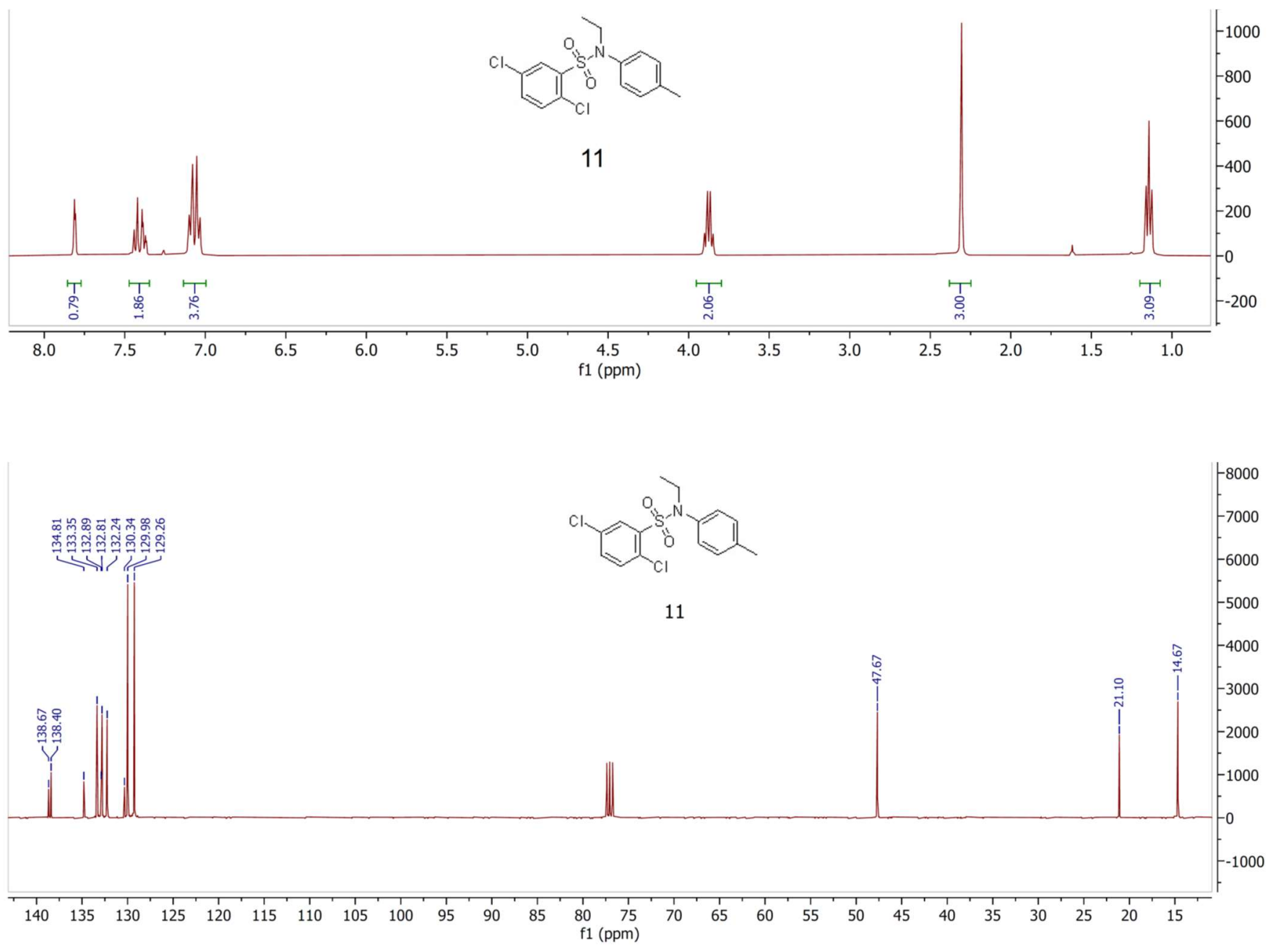

S16 


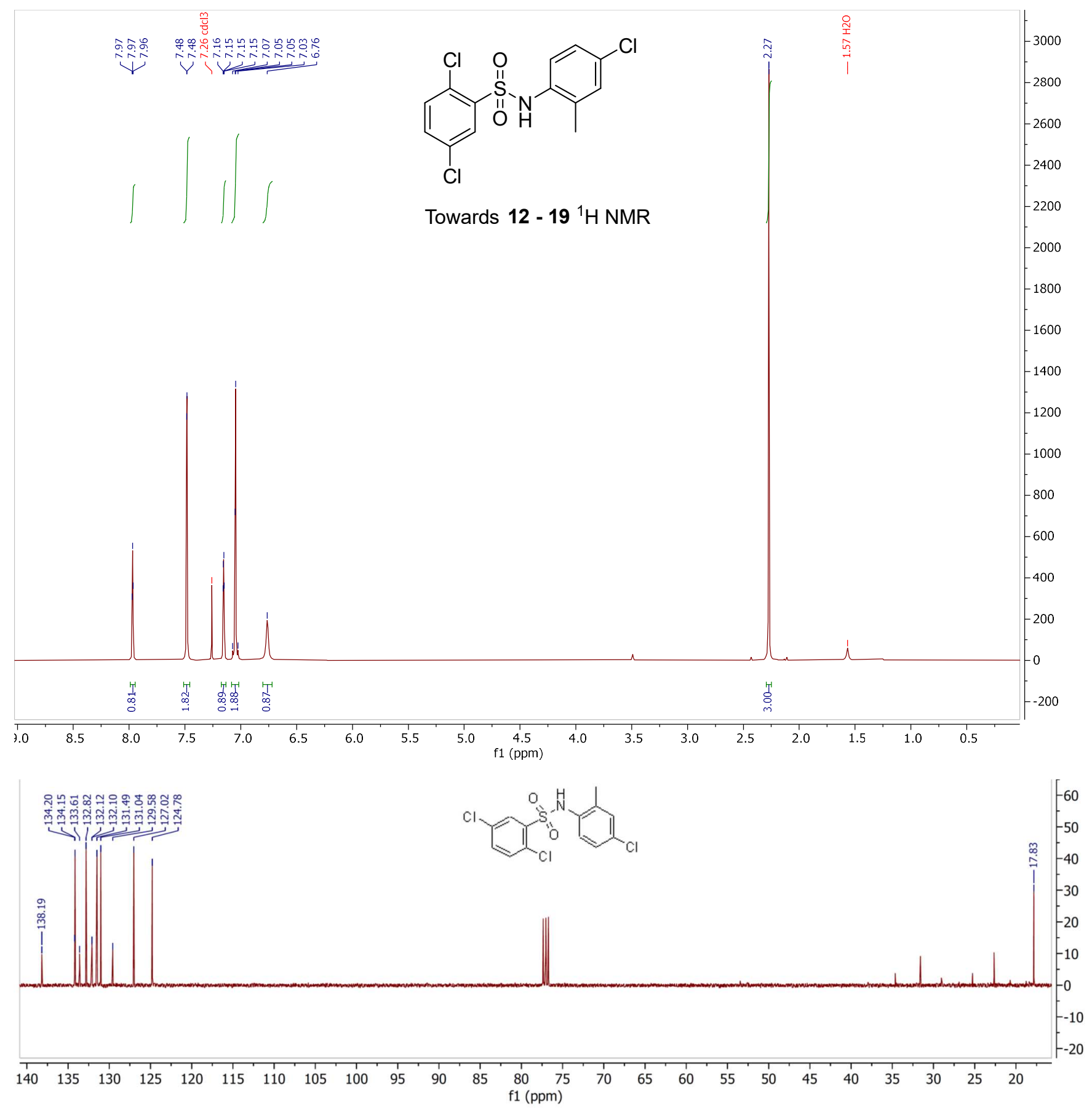




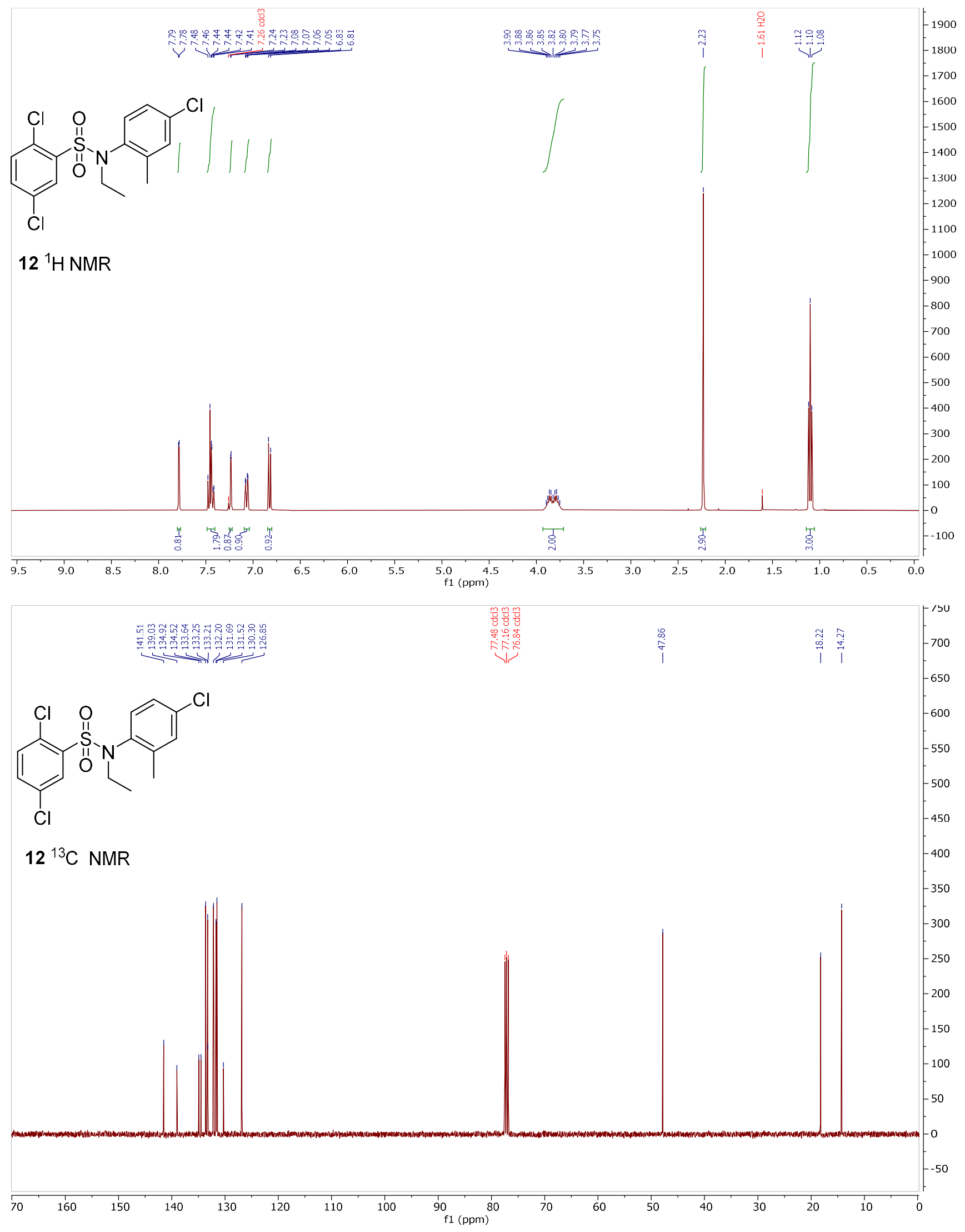




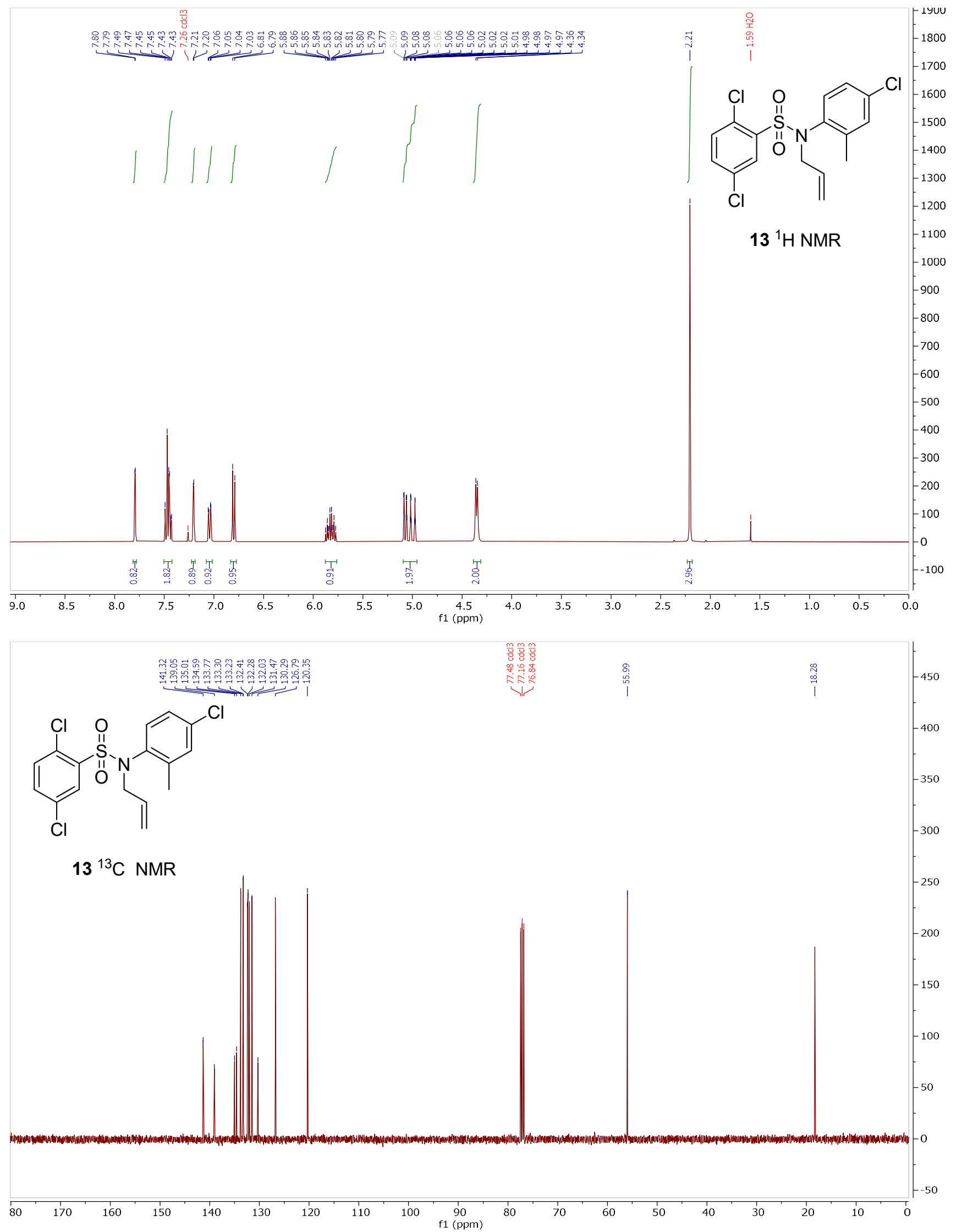




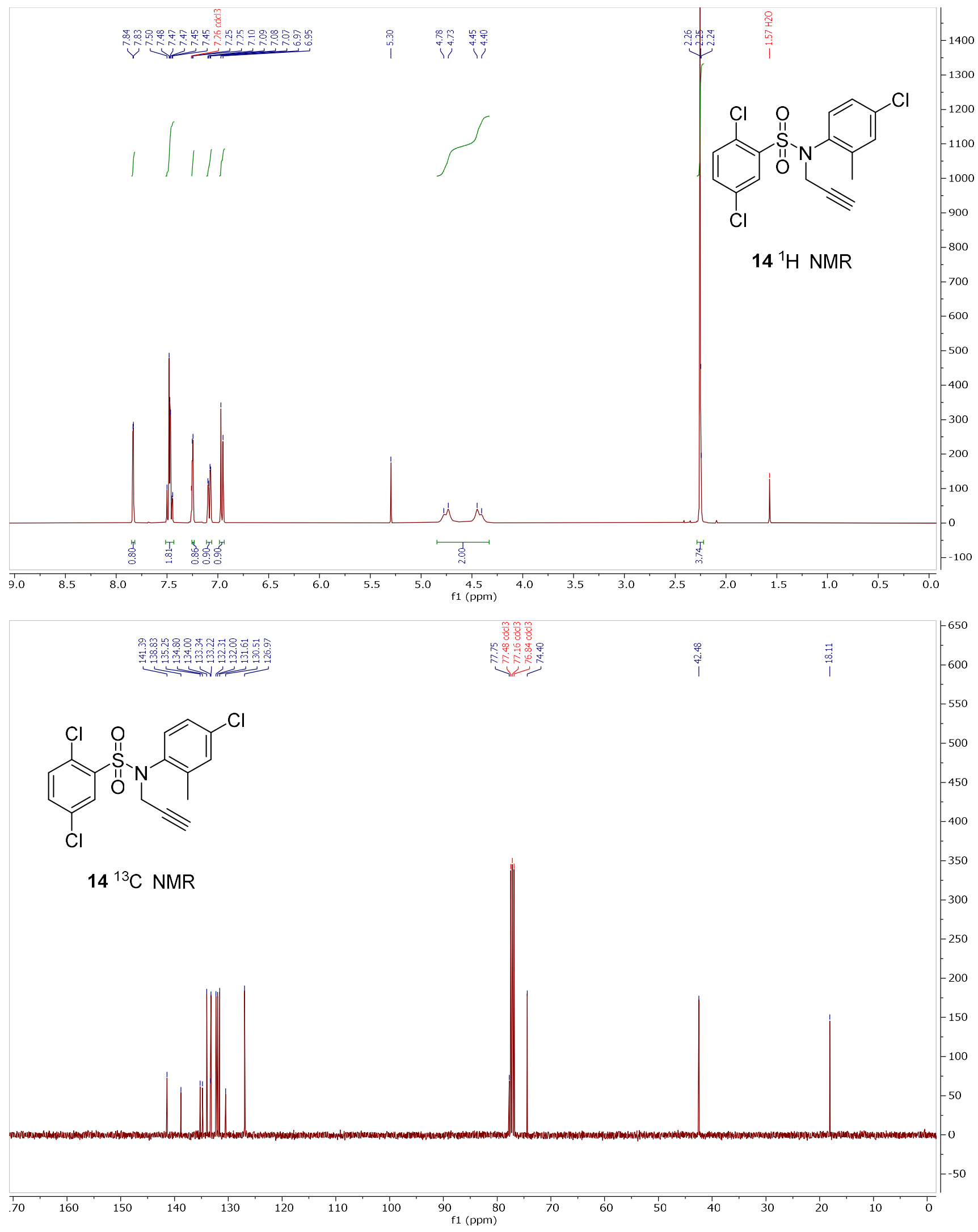



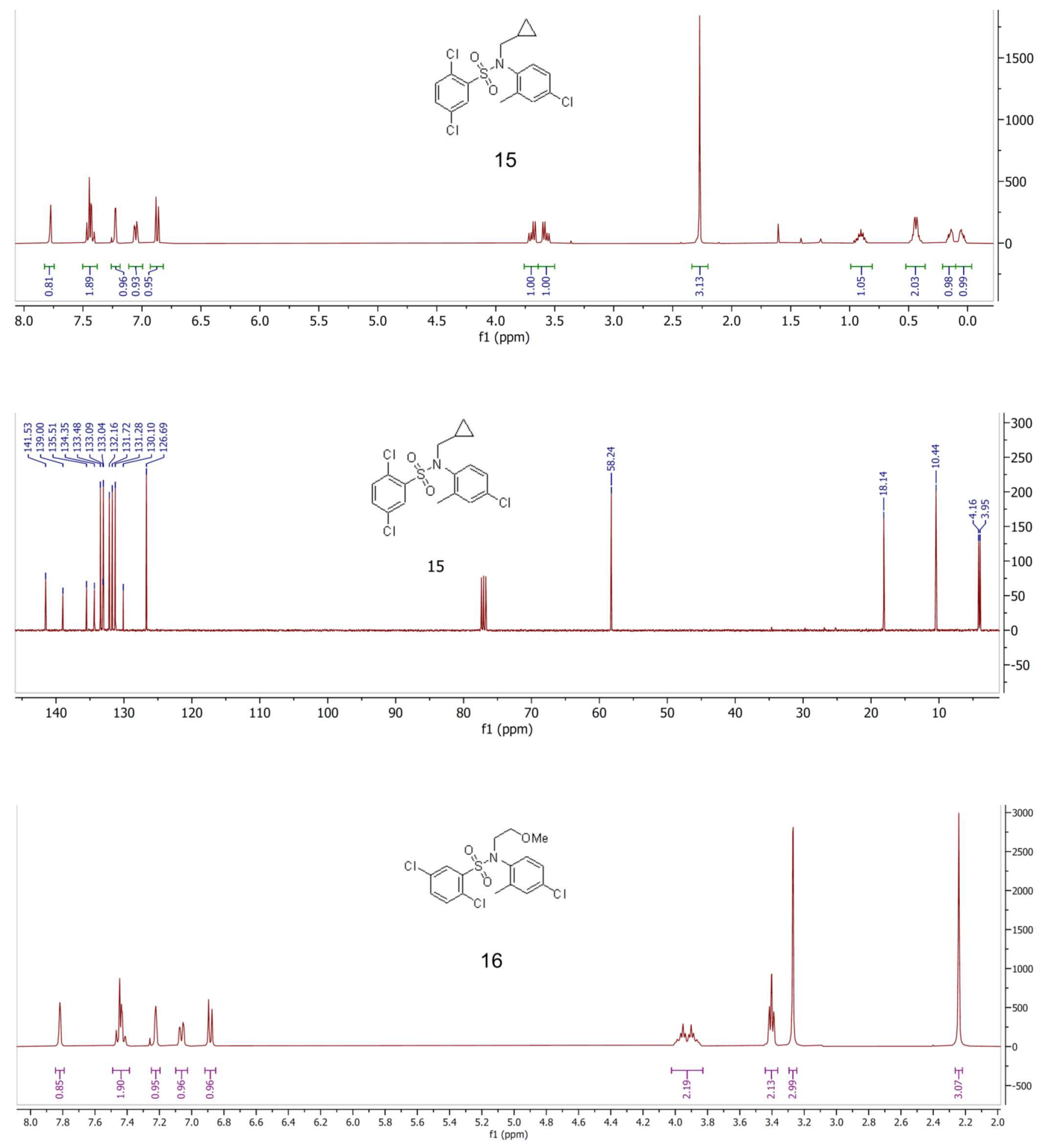

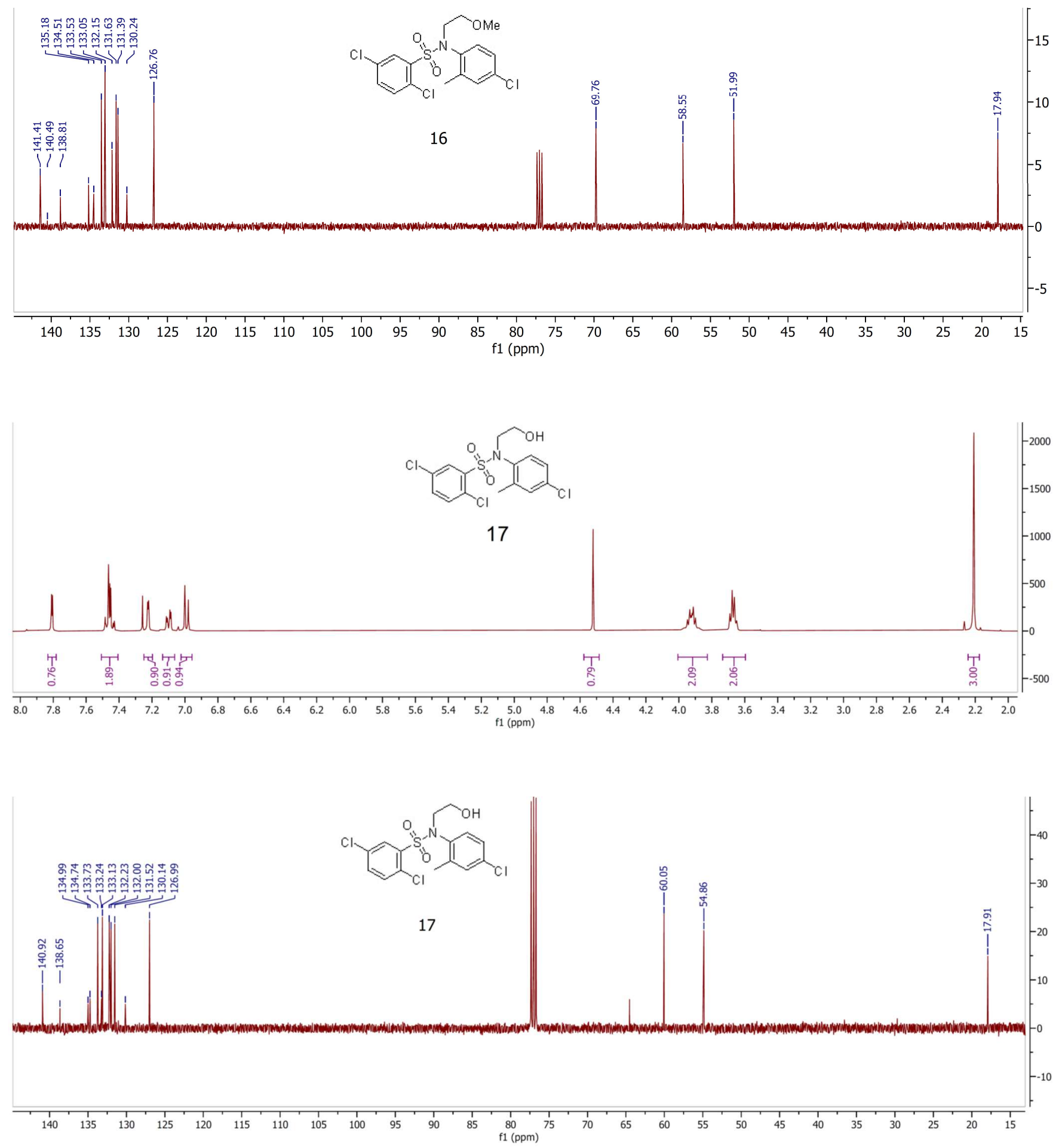

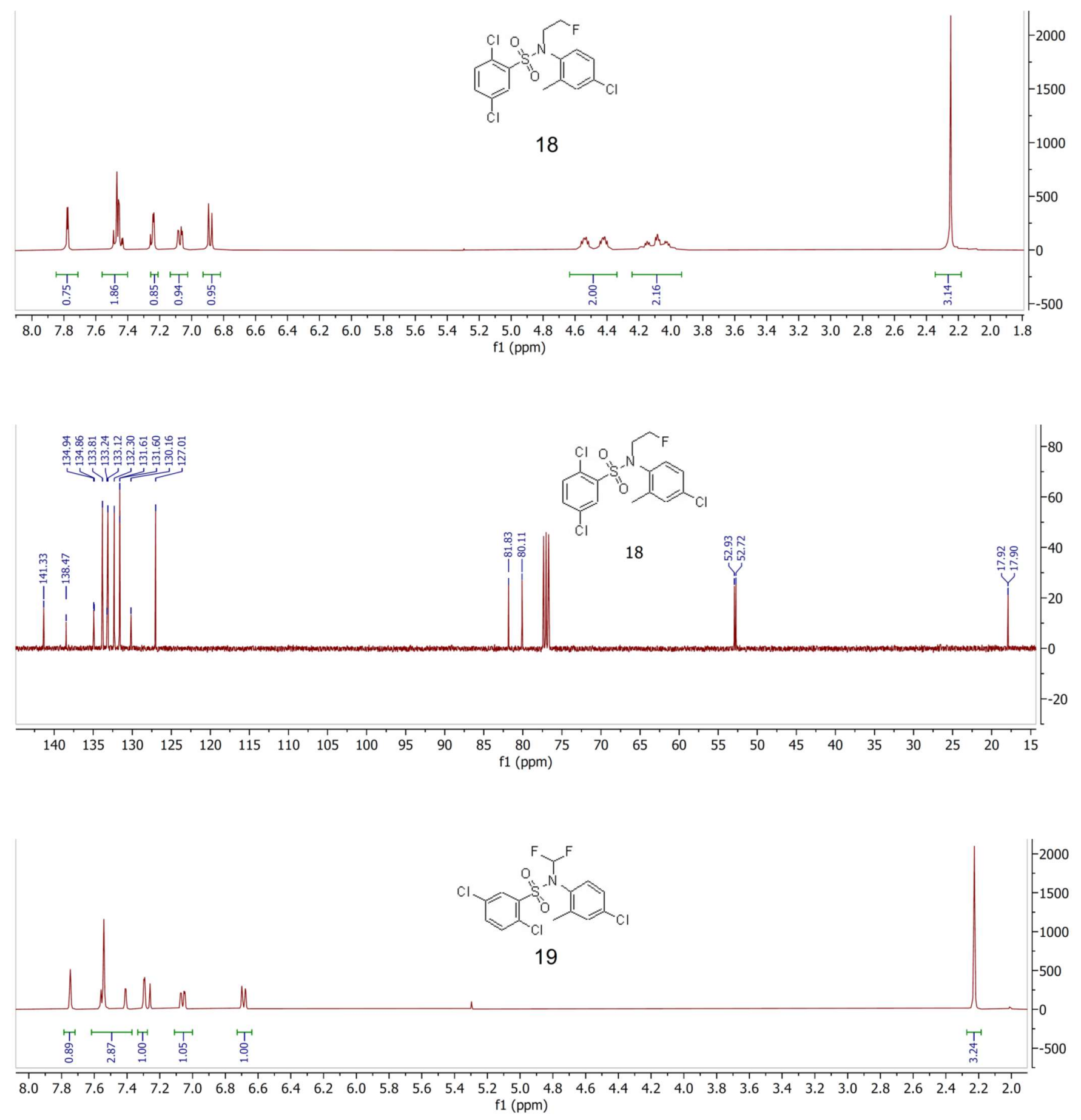

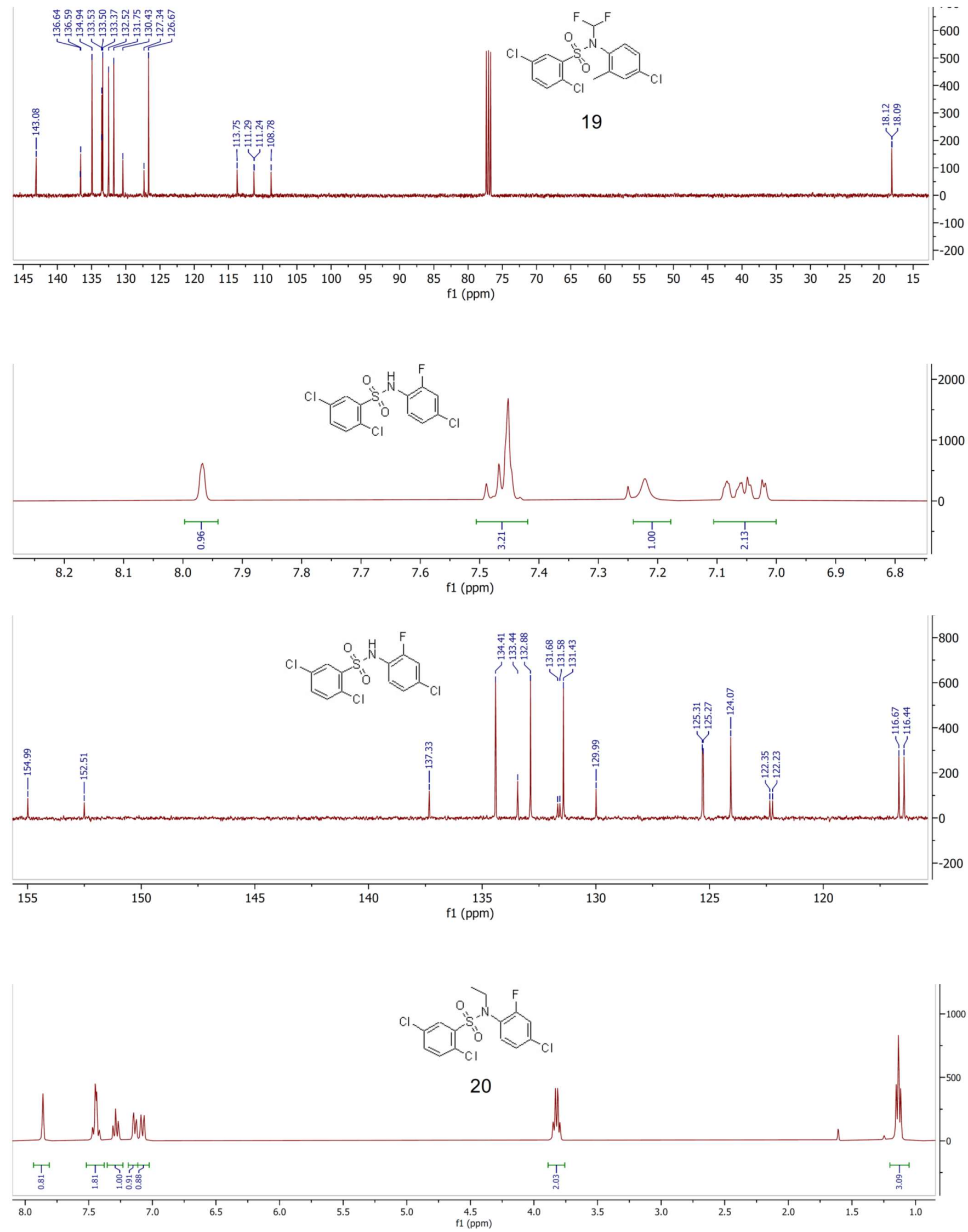

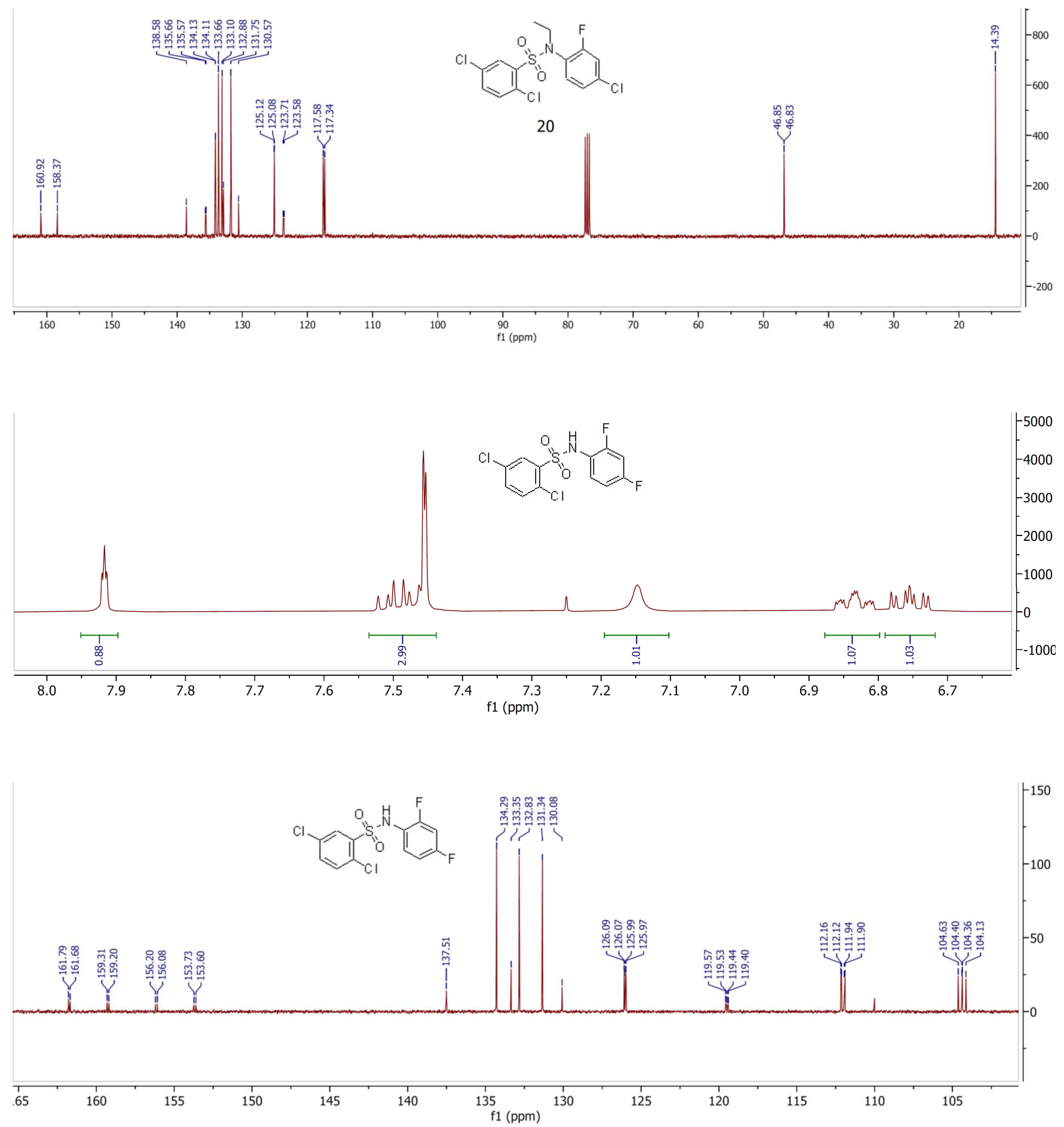

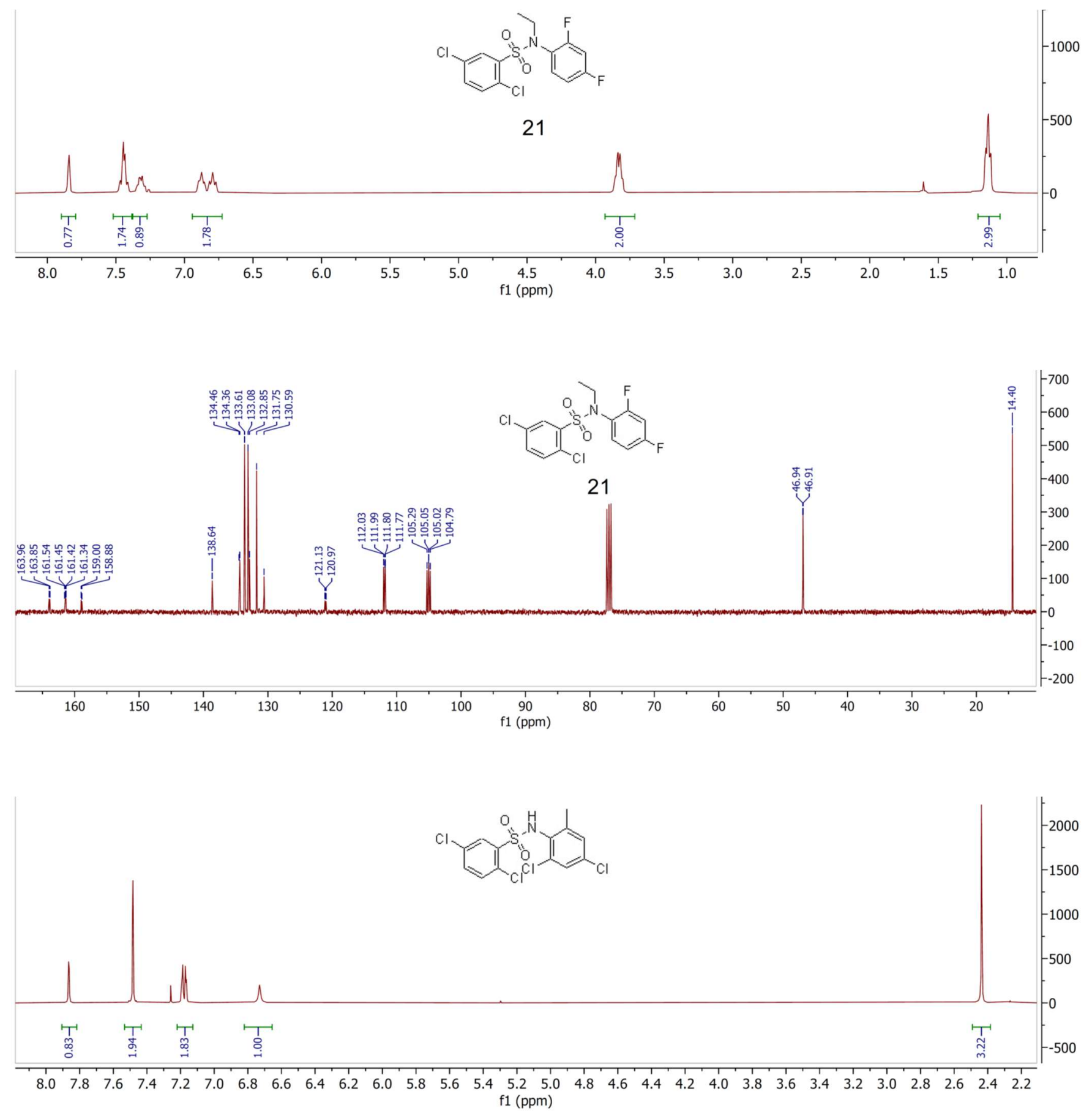

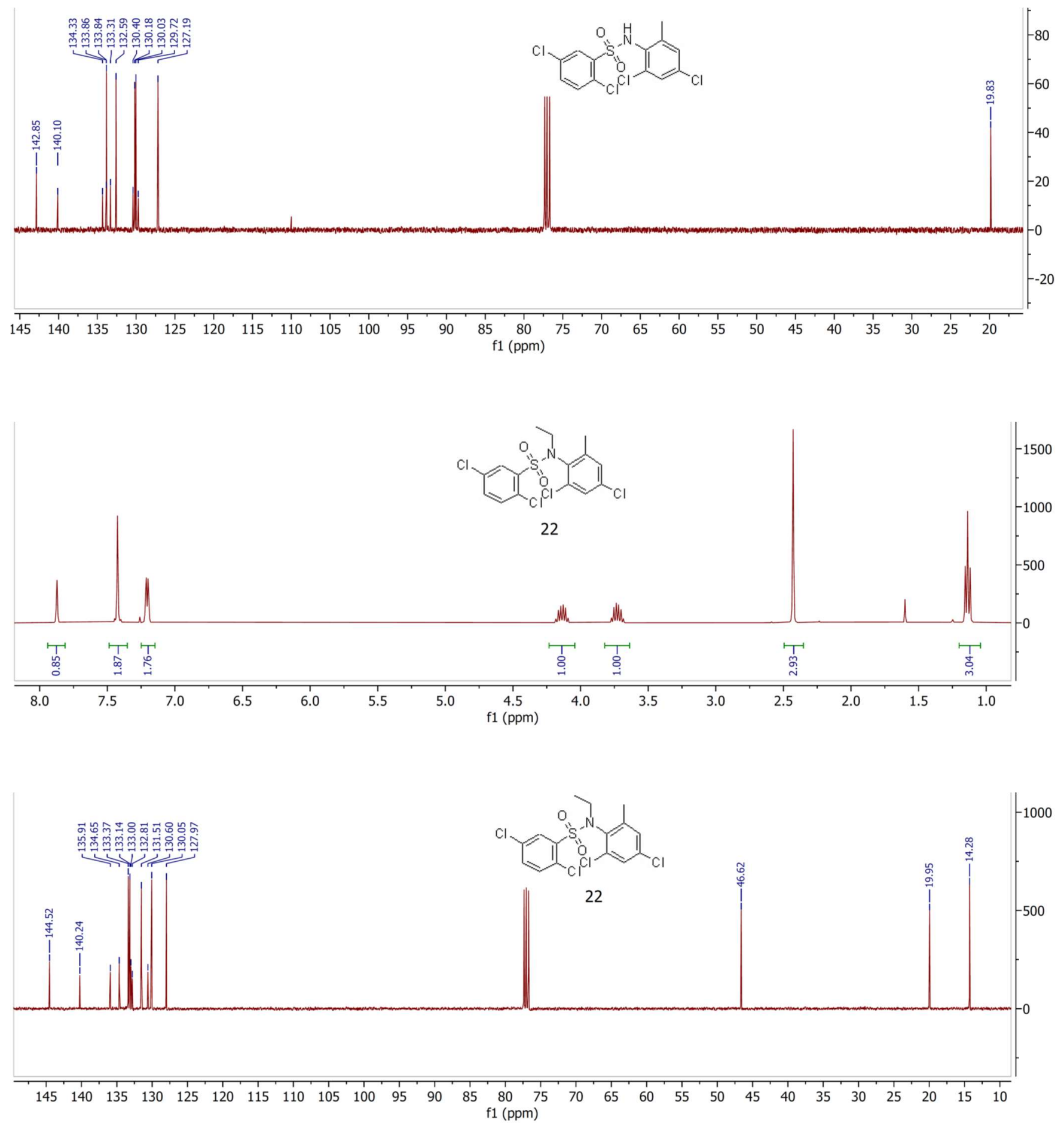

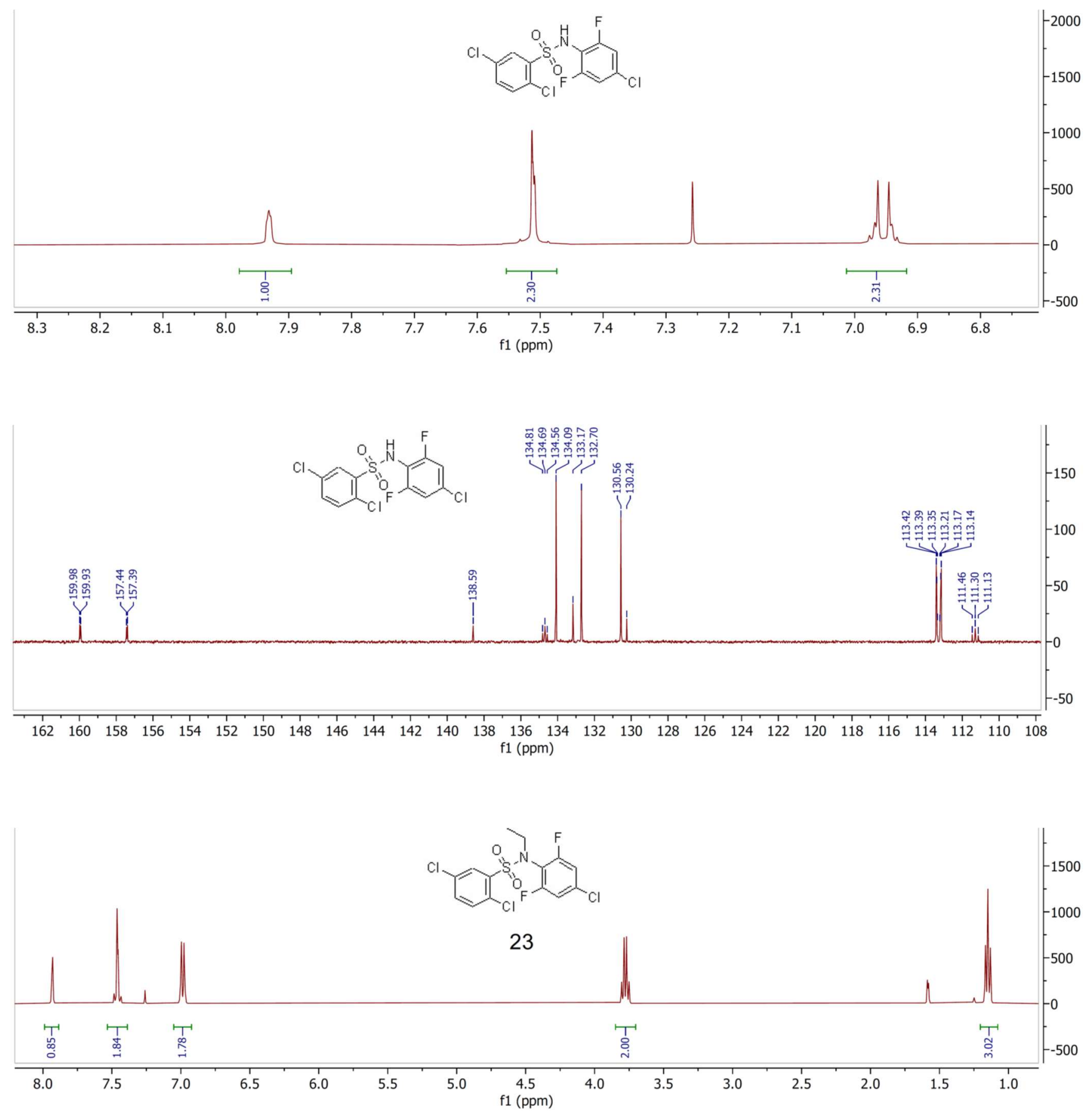

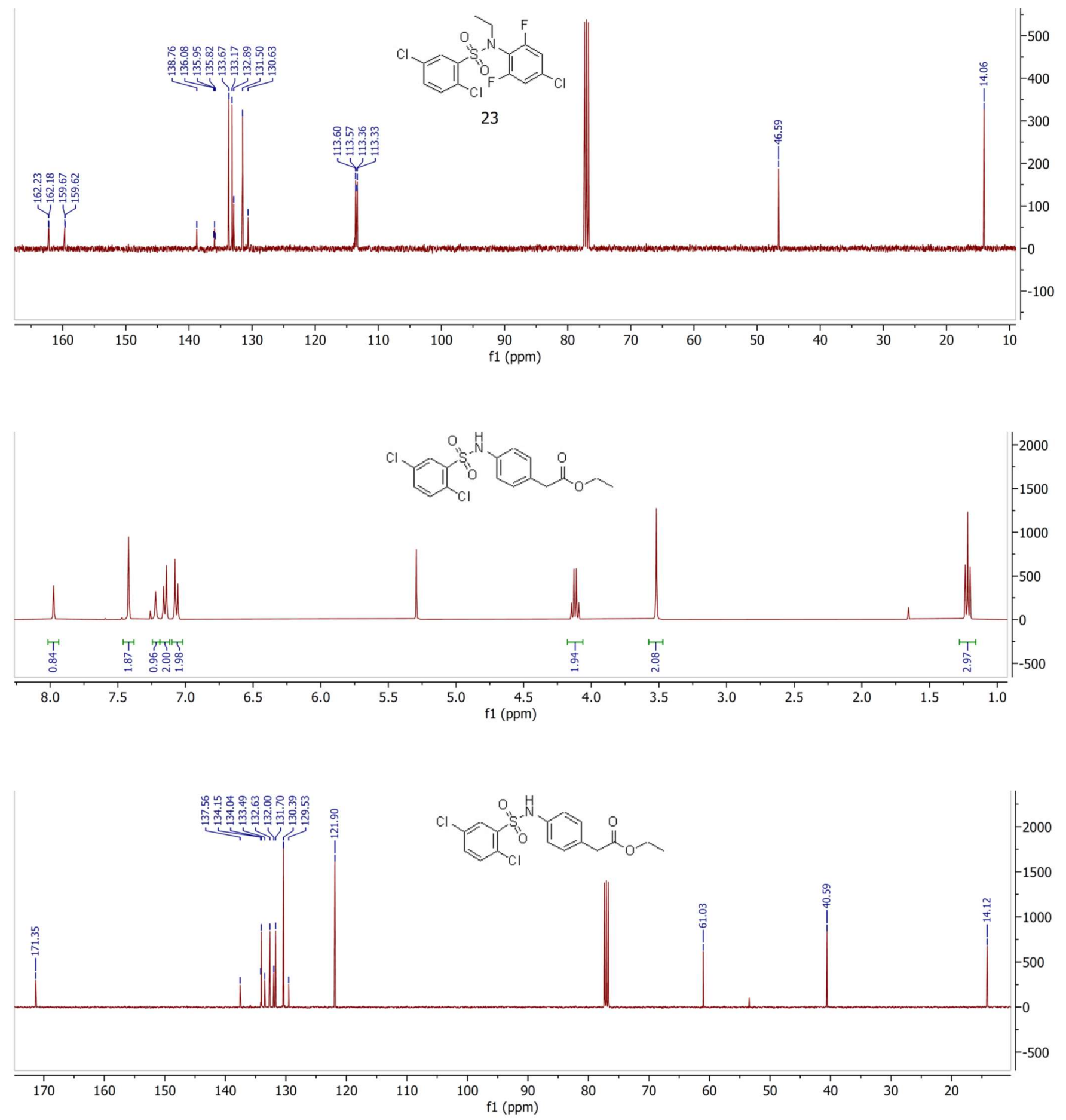

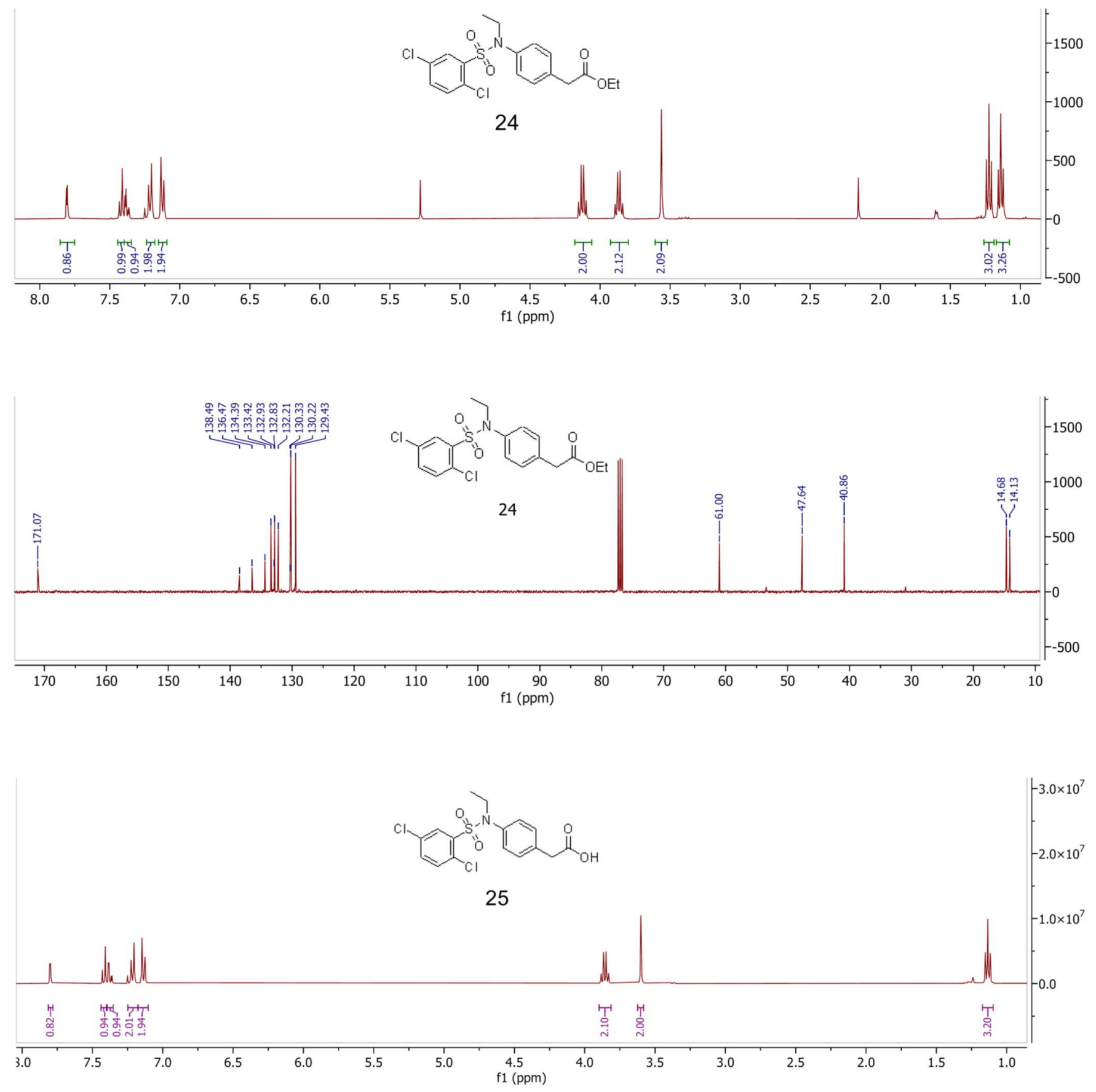

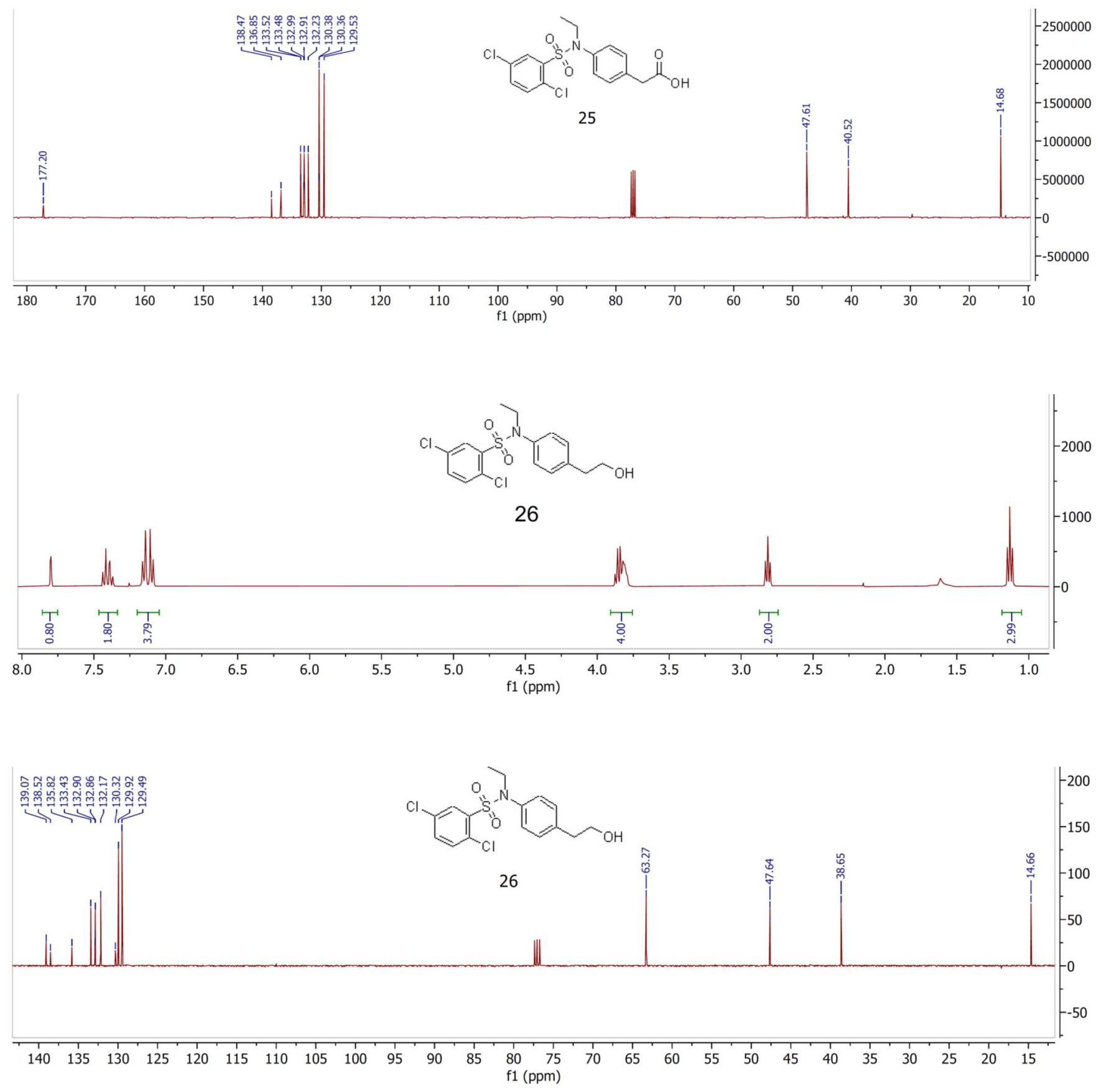

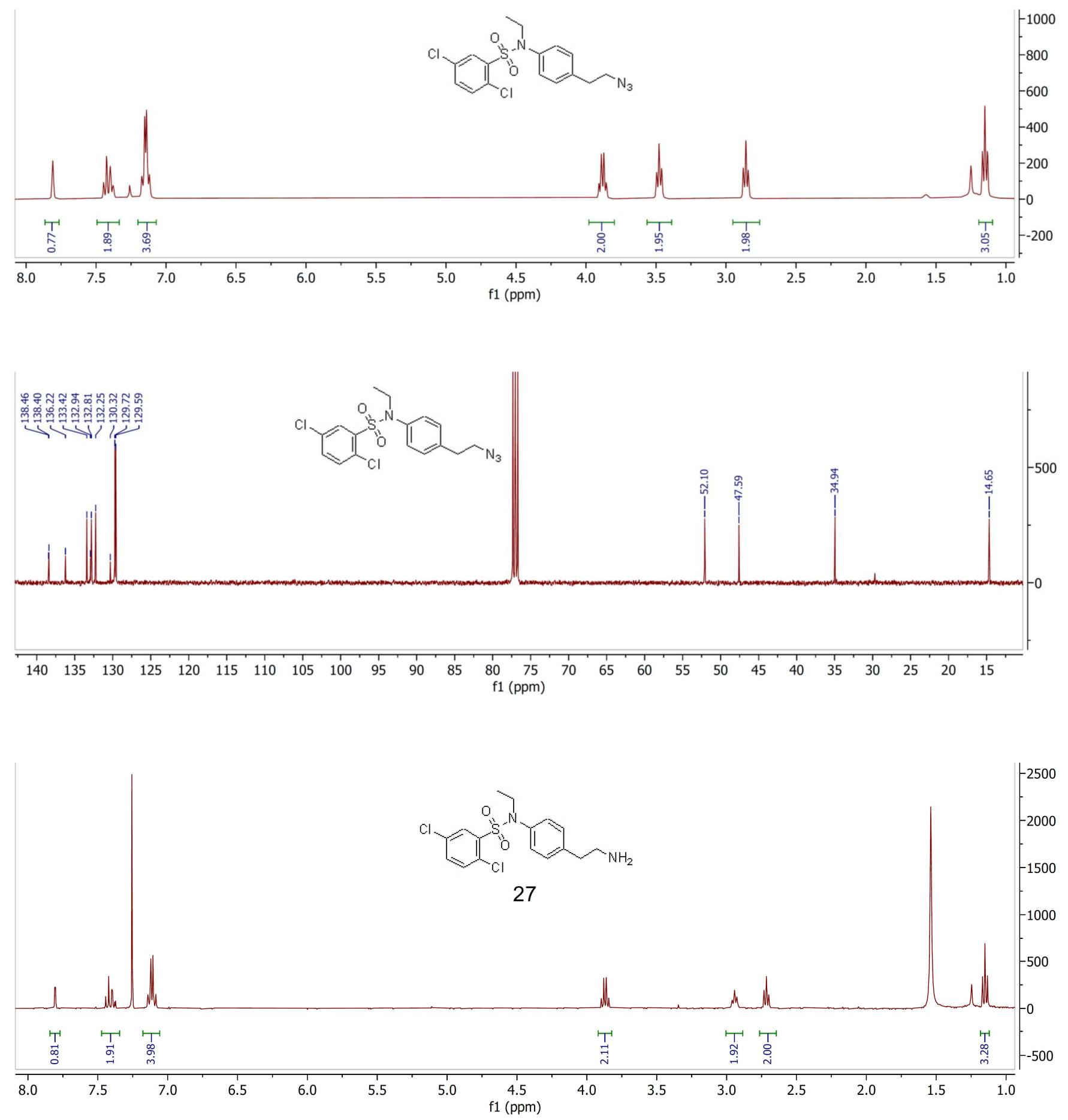

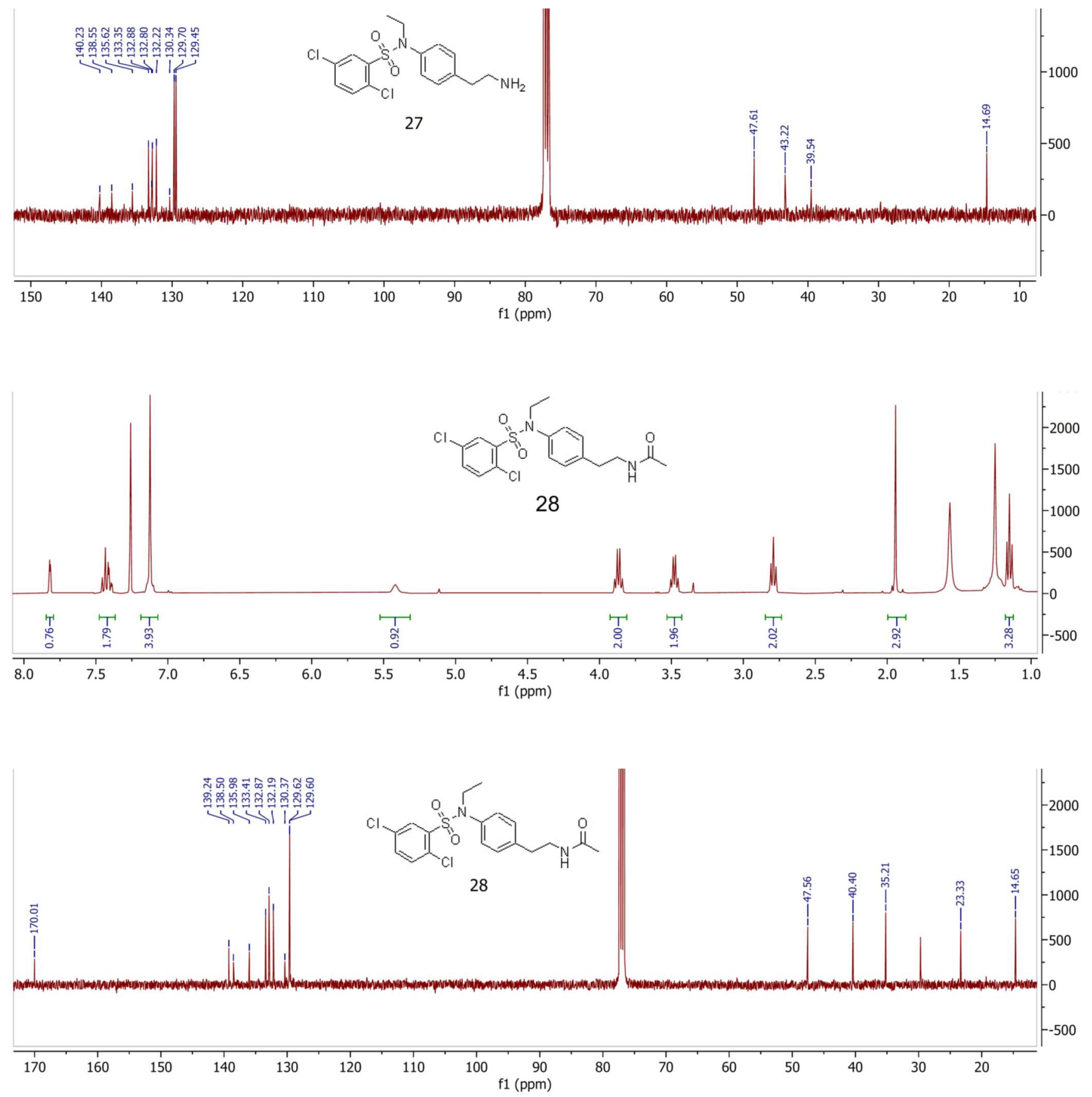

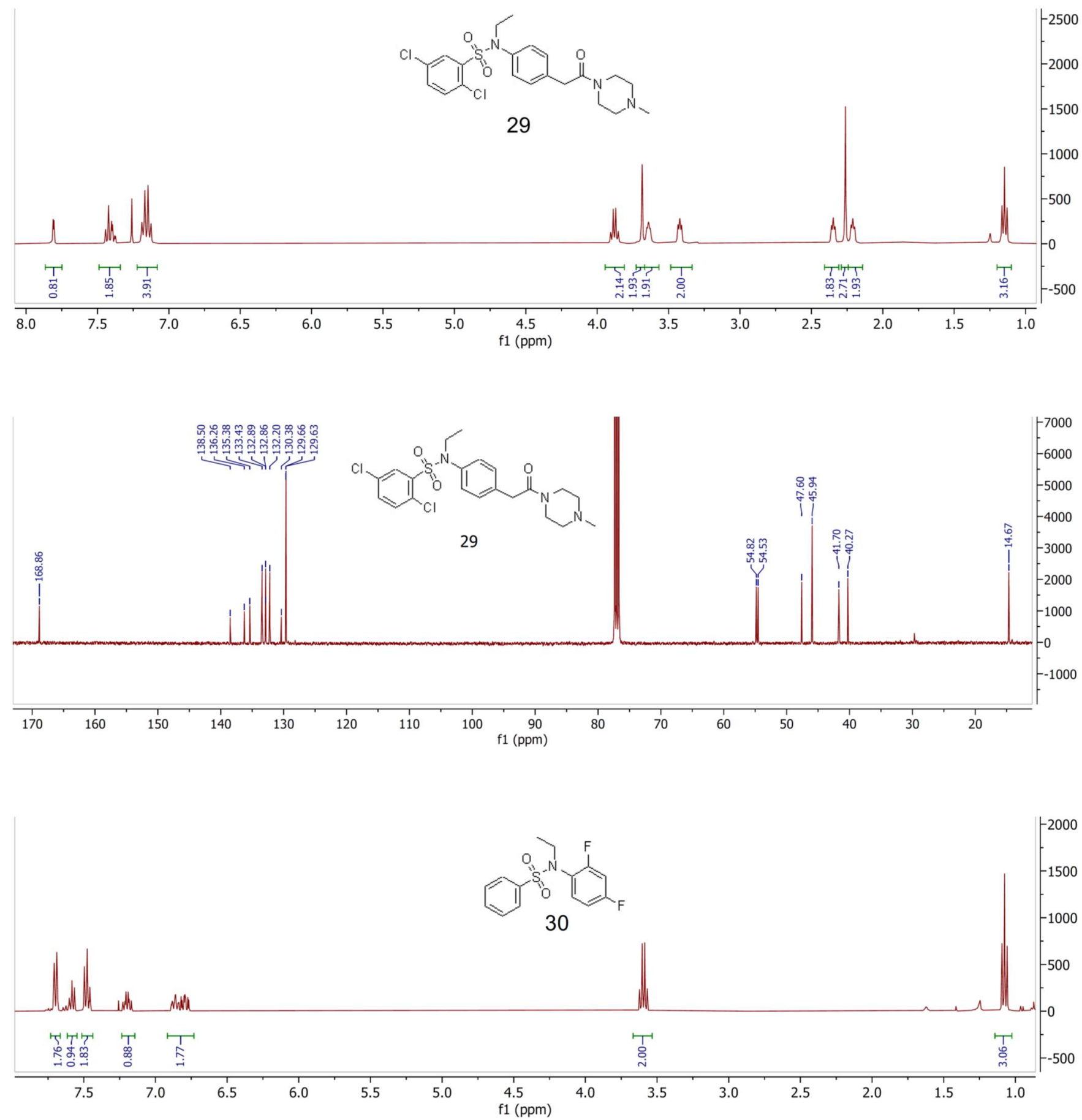

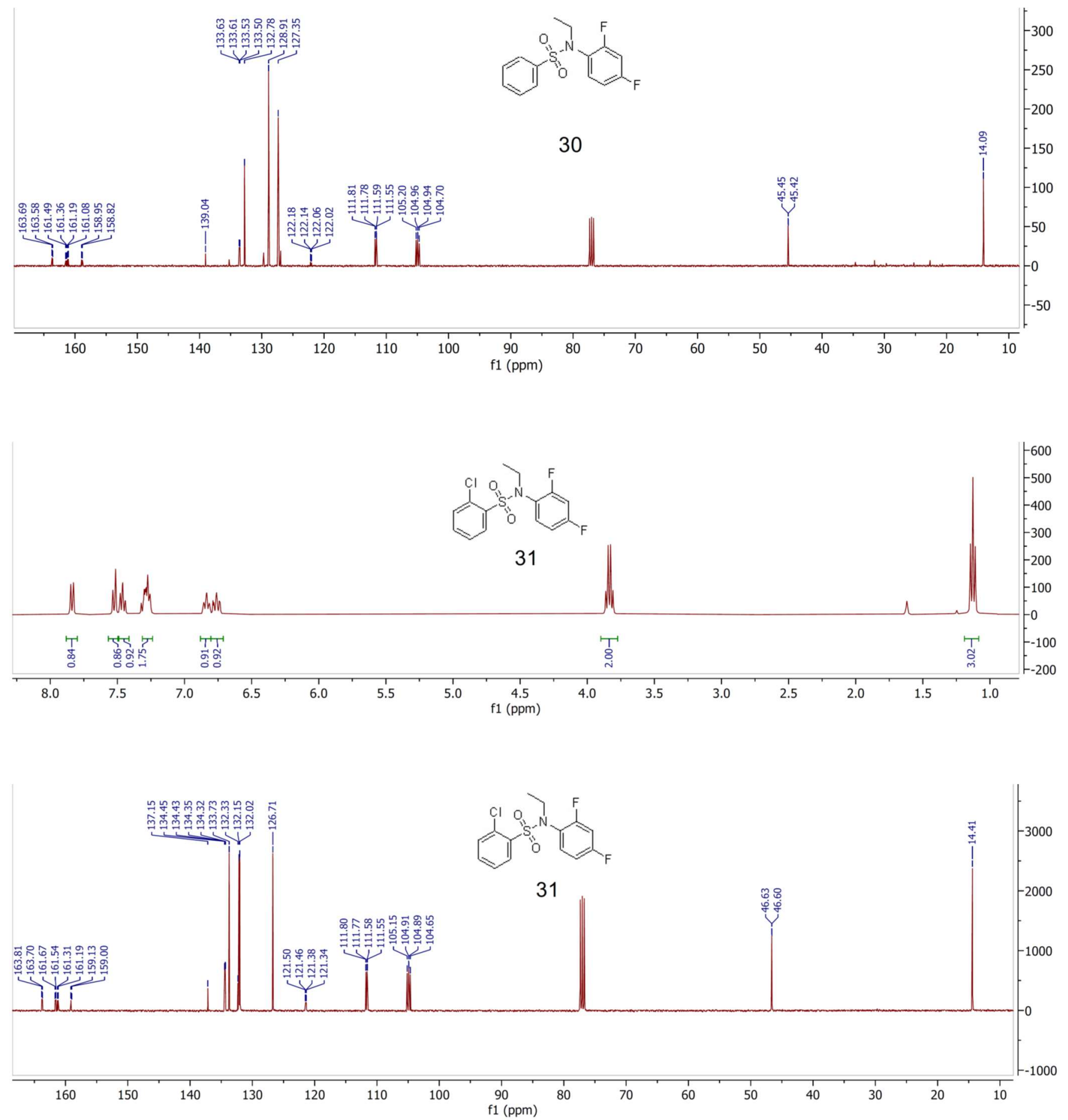

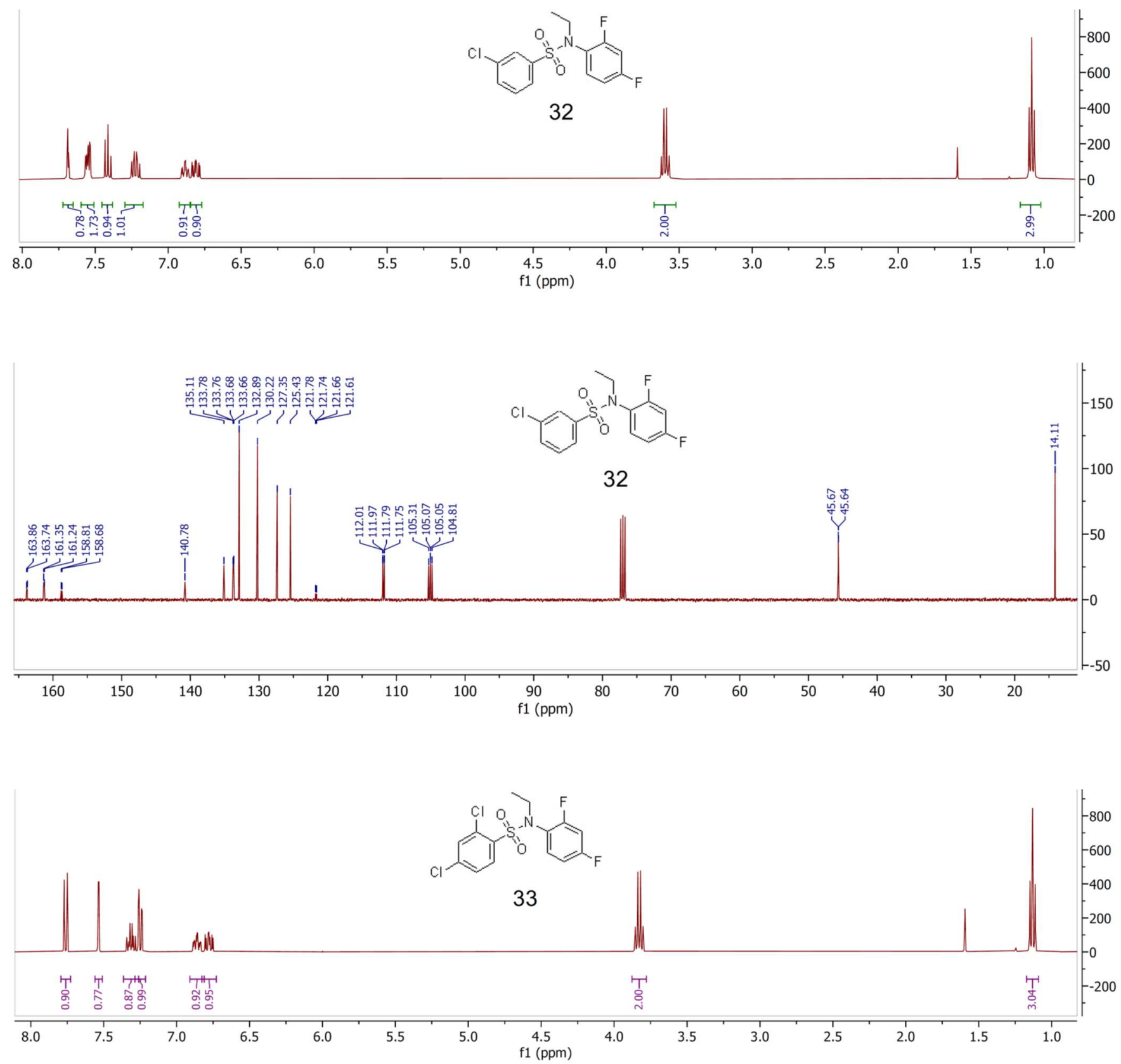

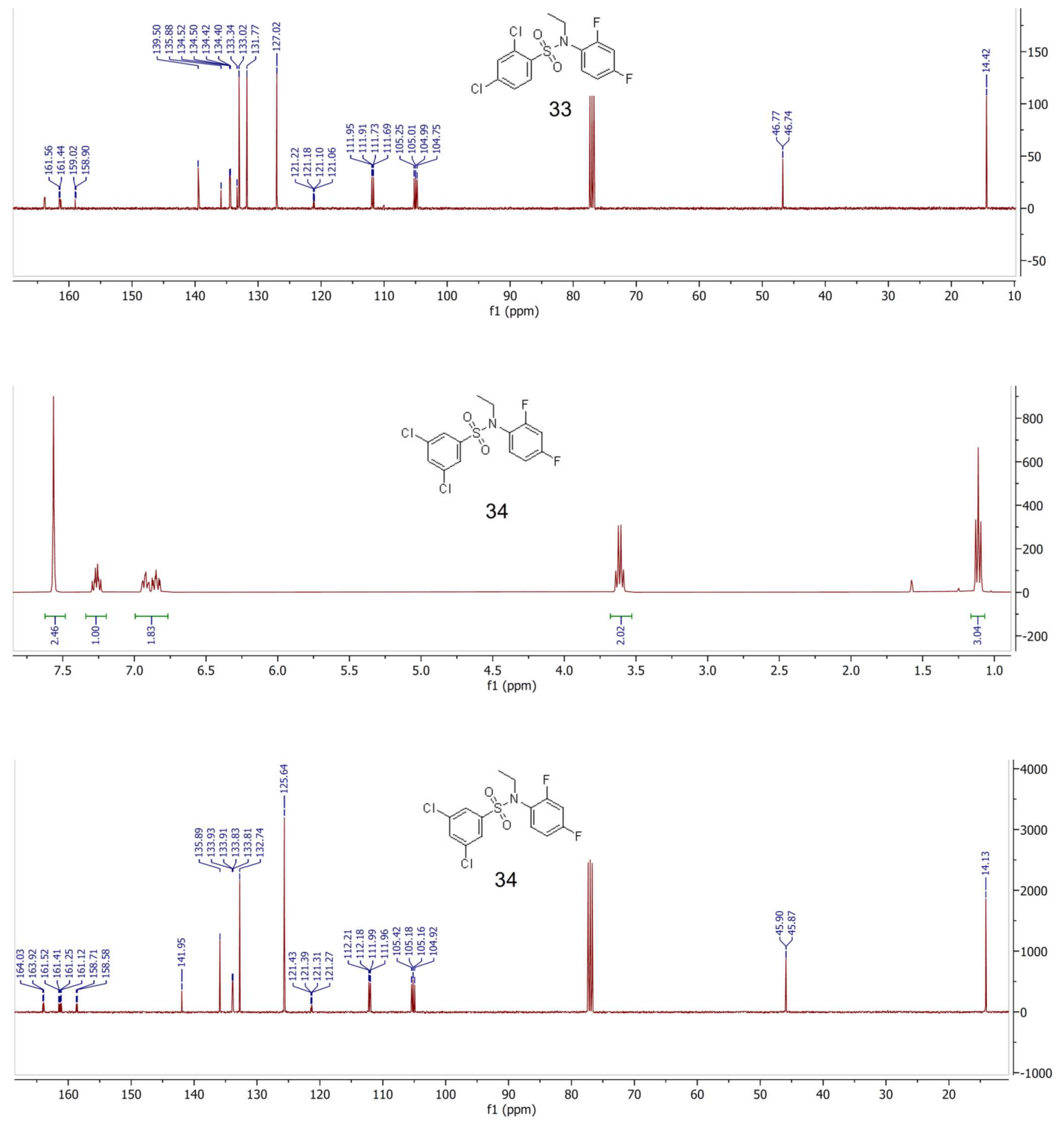

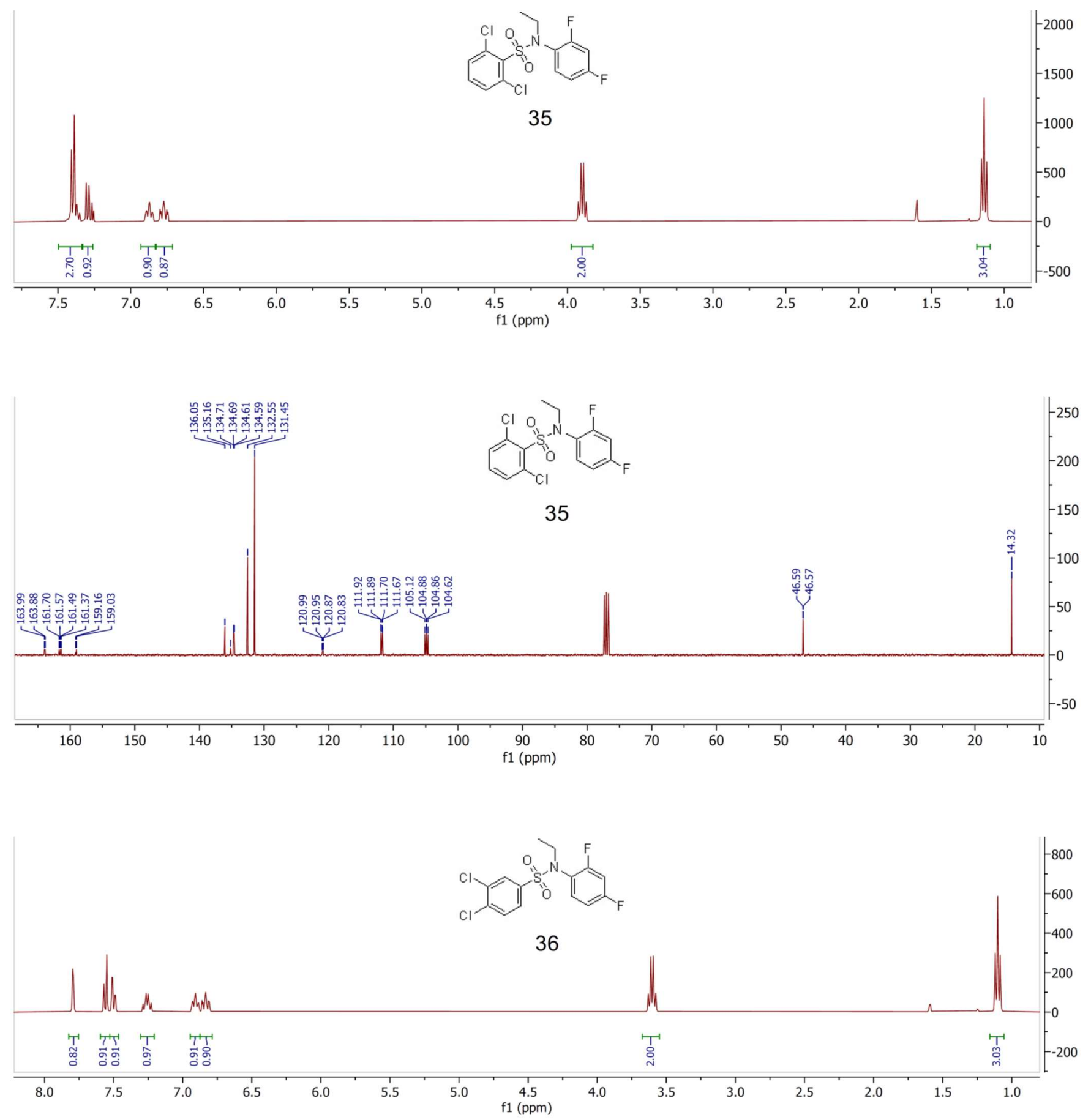

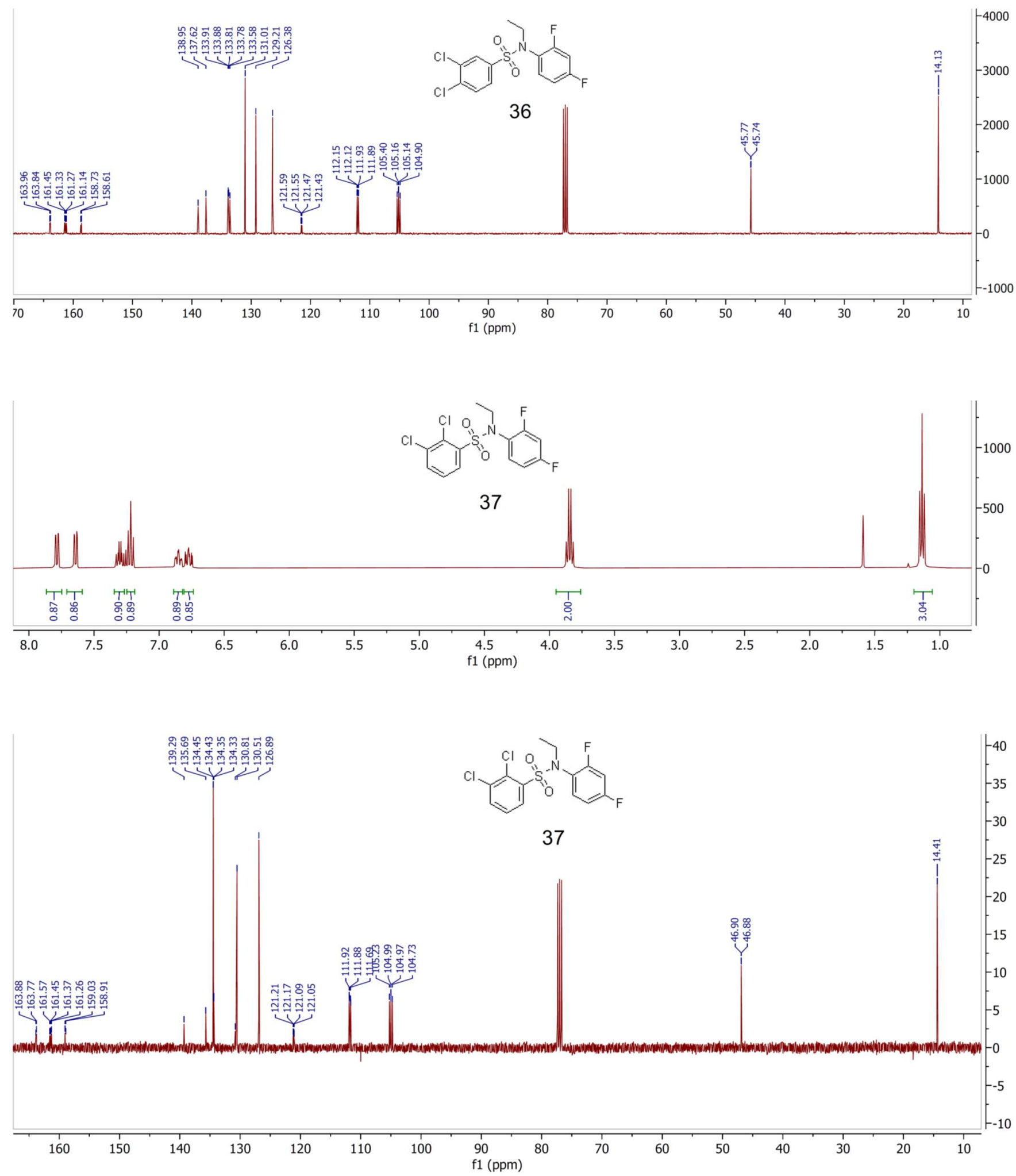

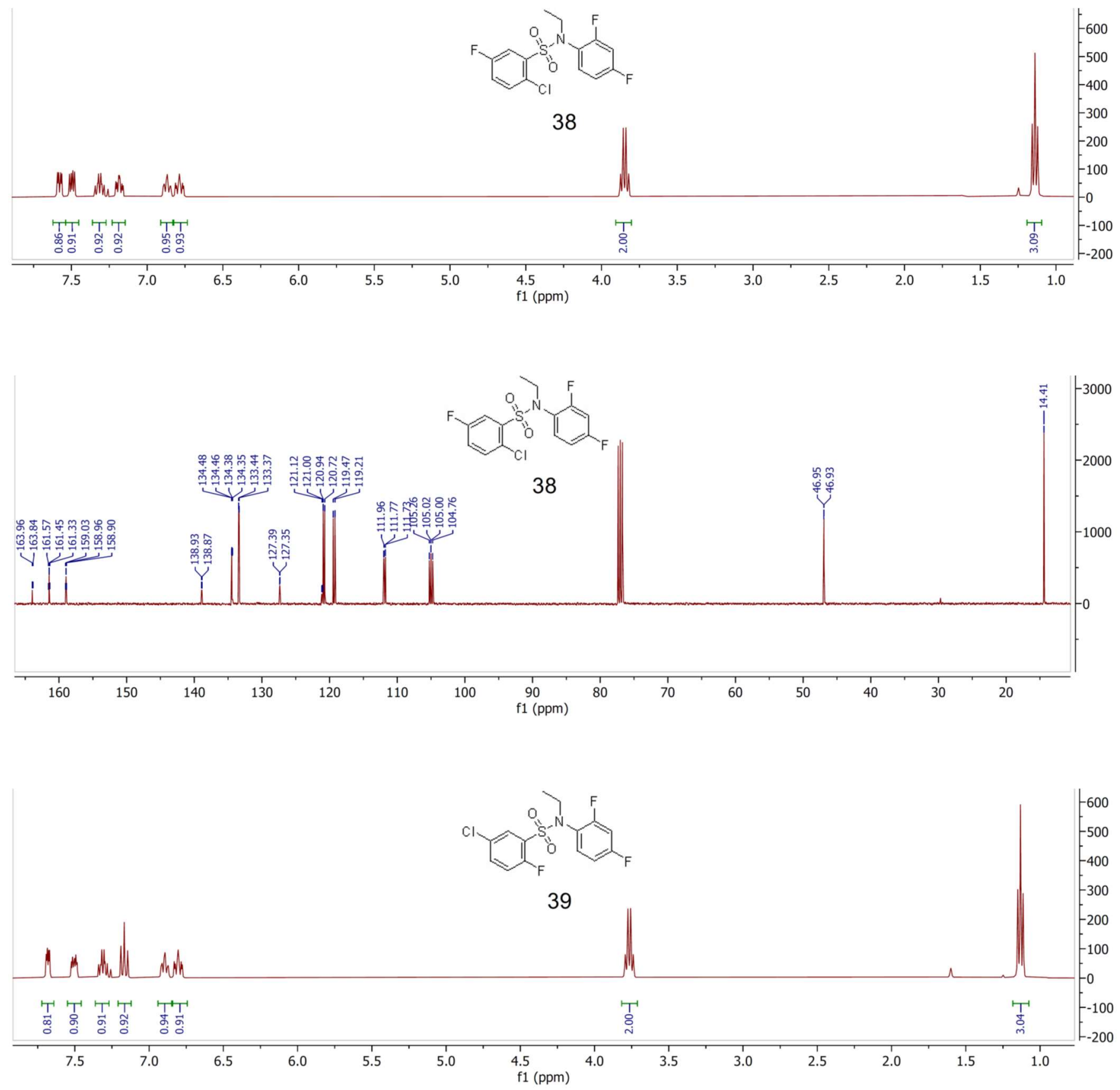

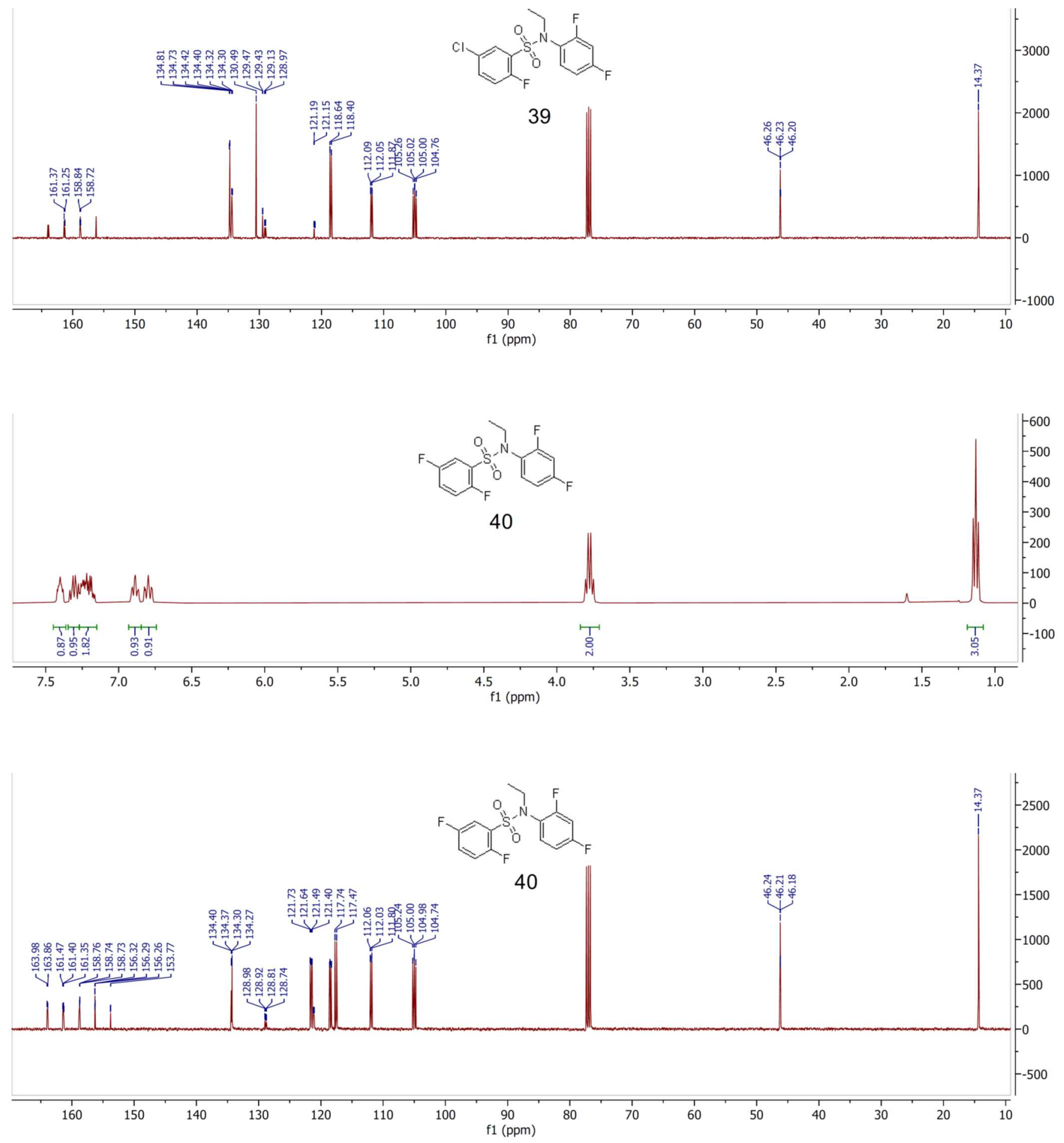


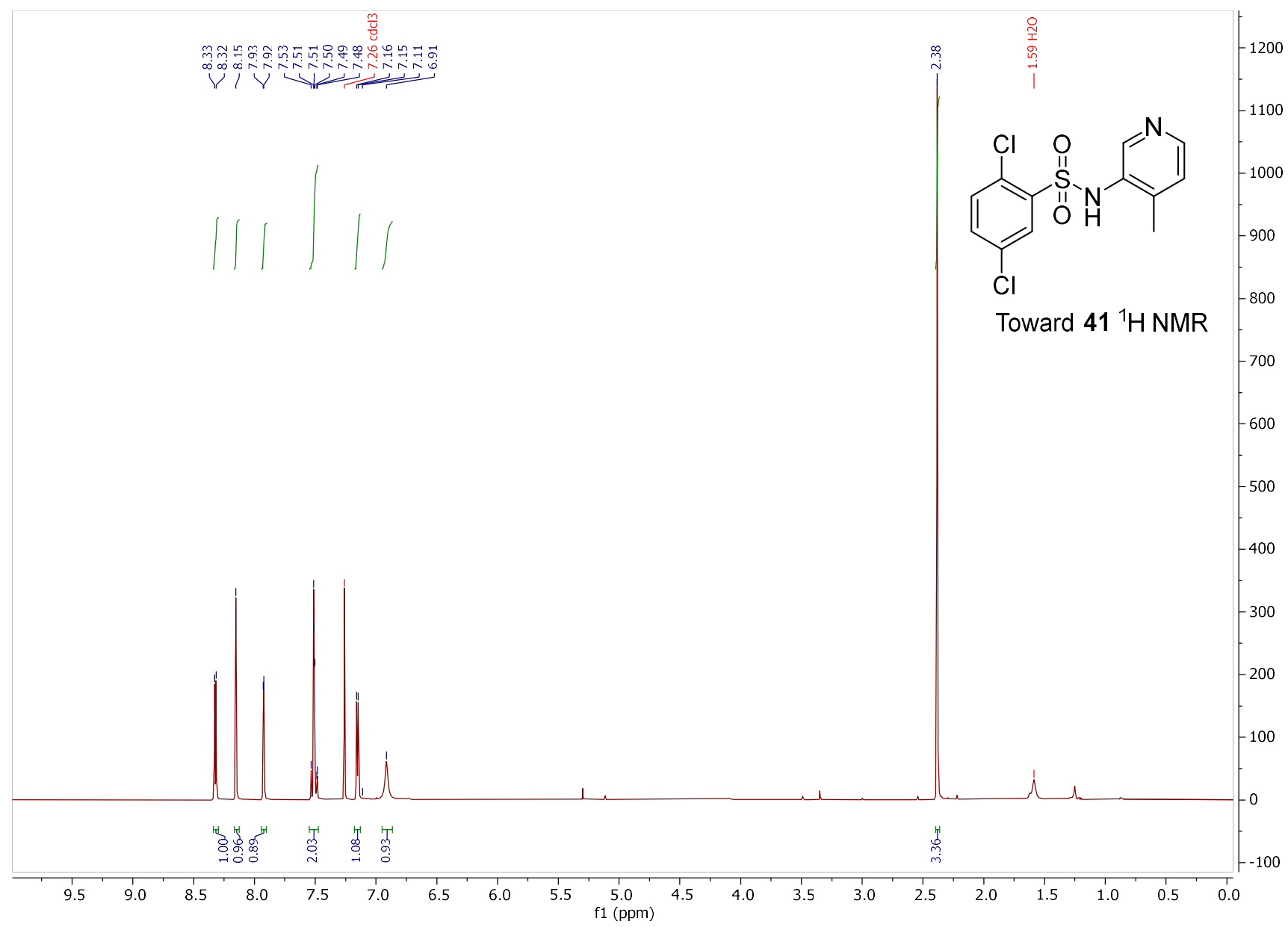




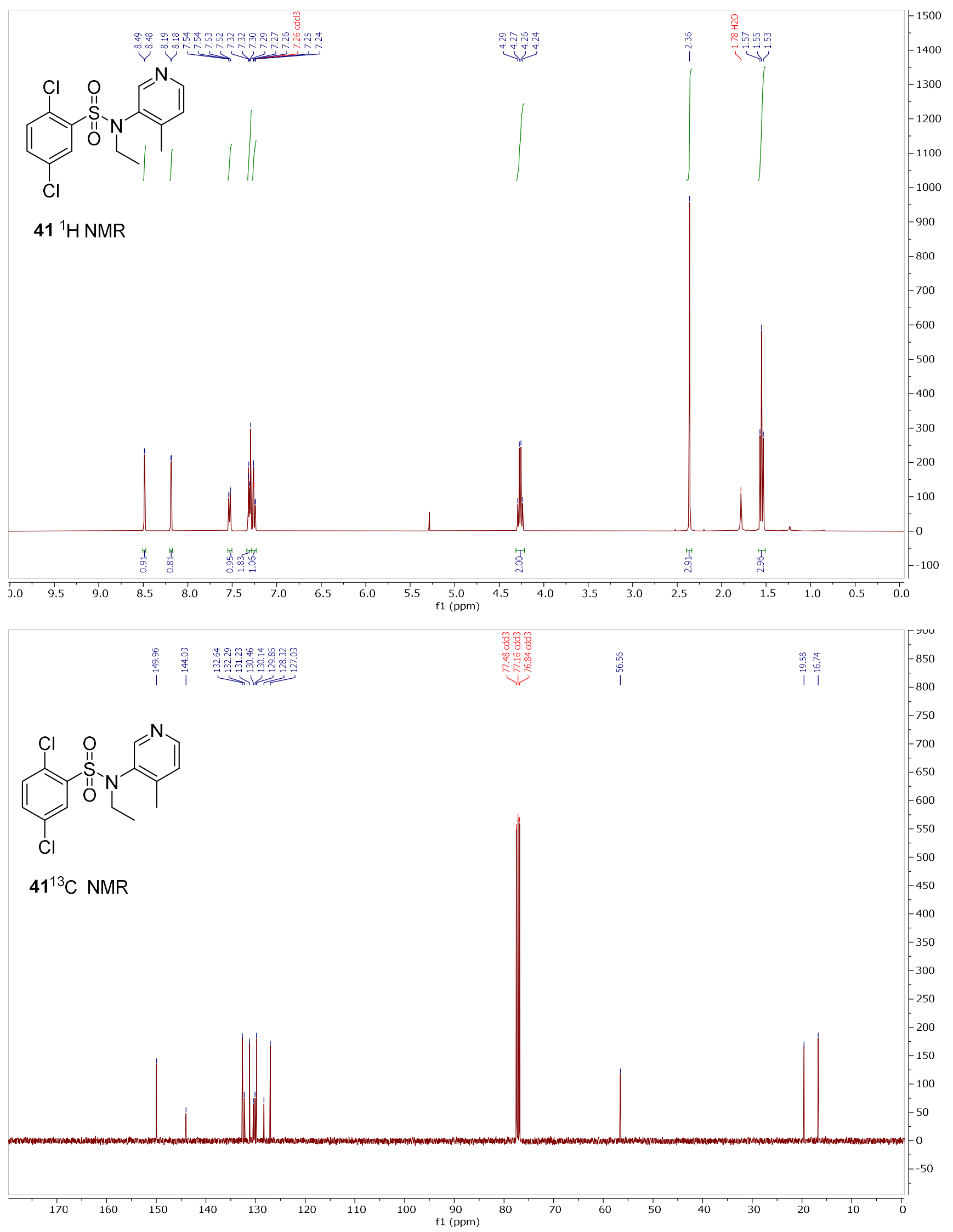



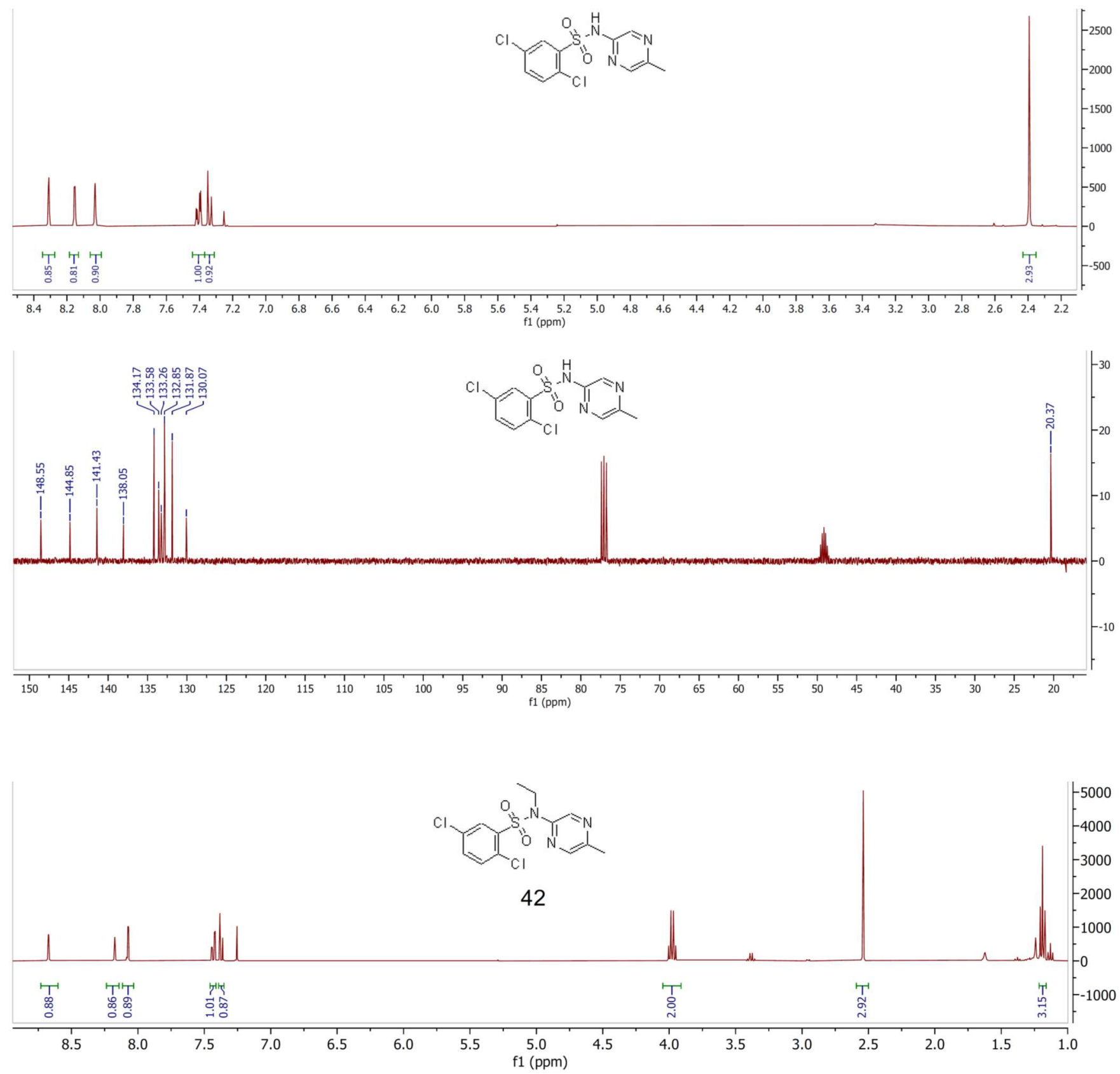

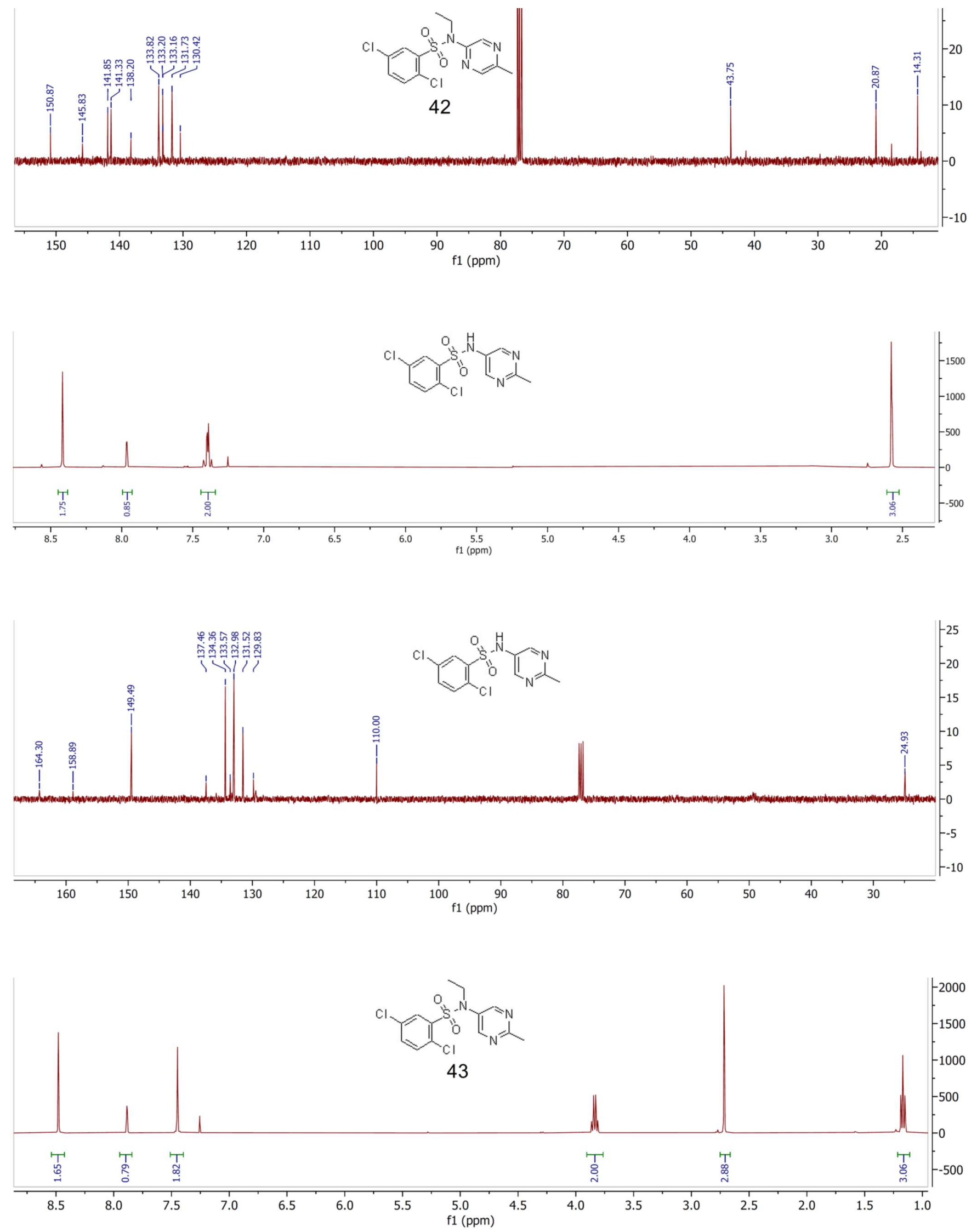

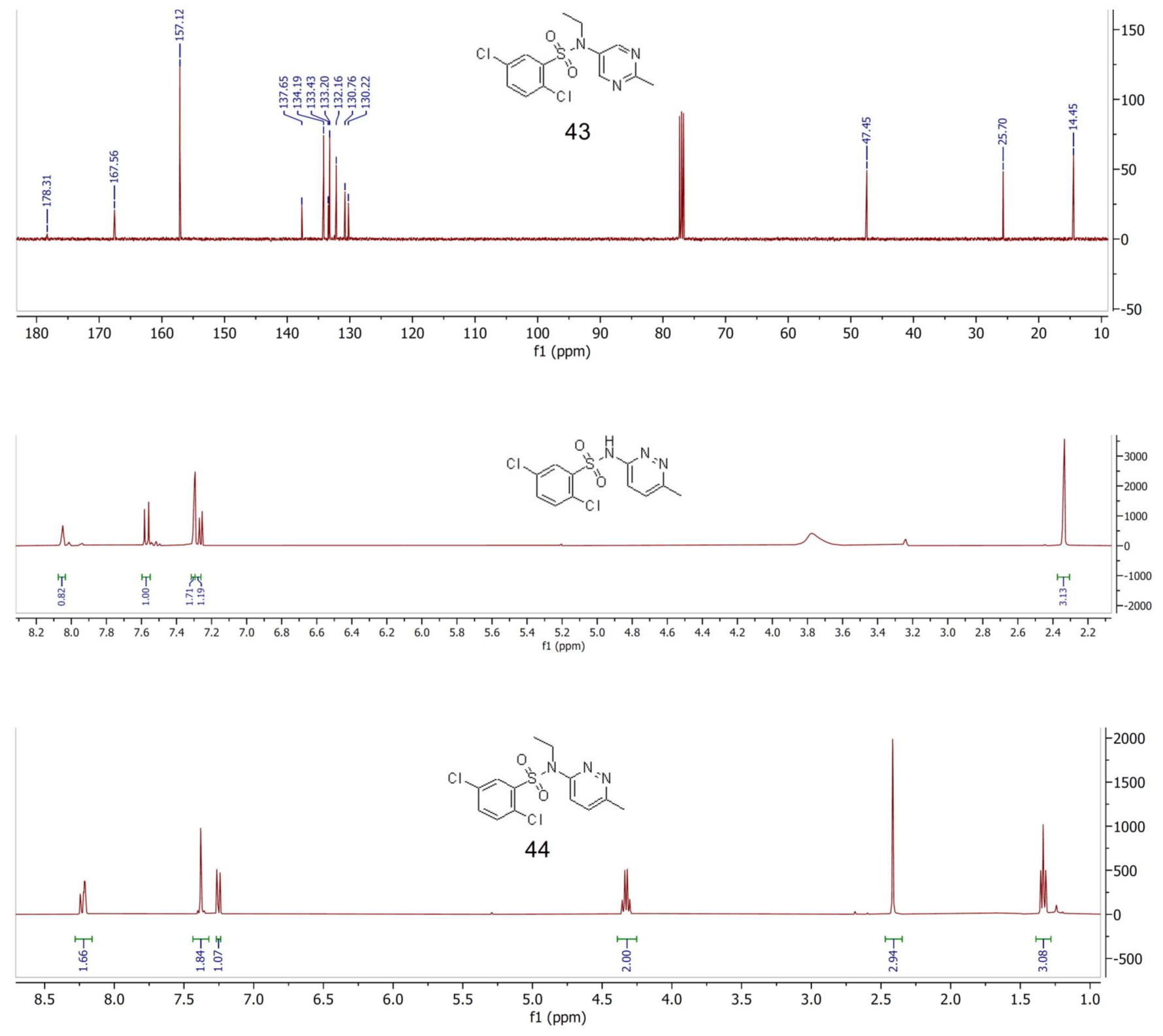

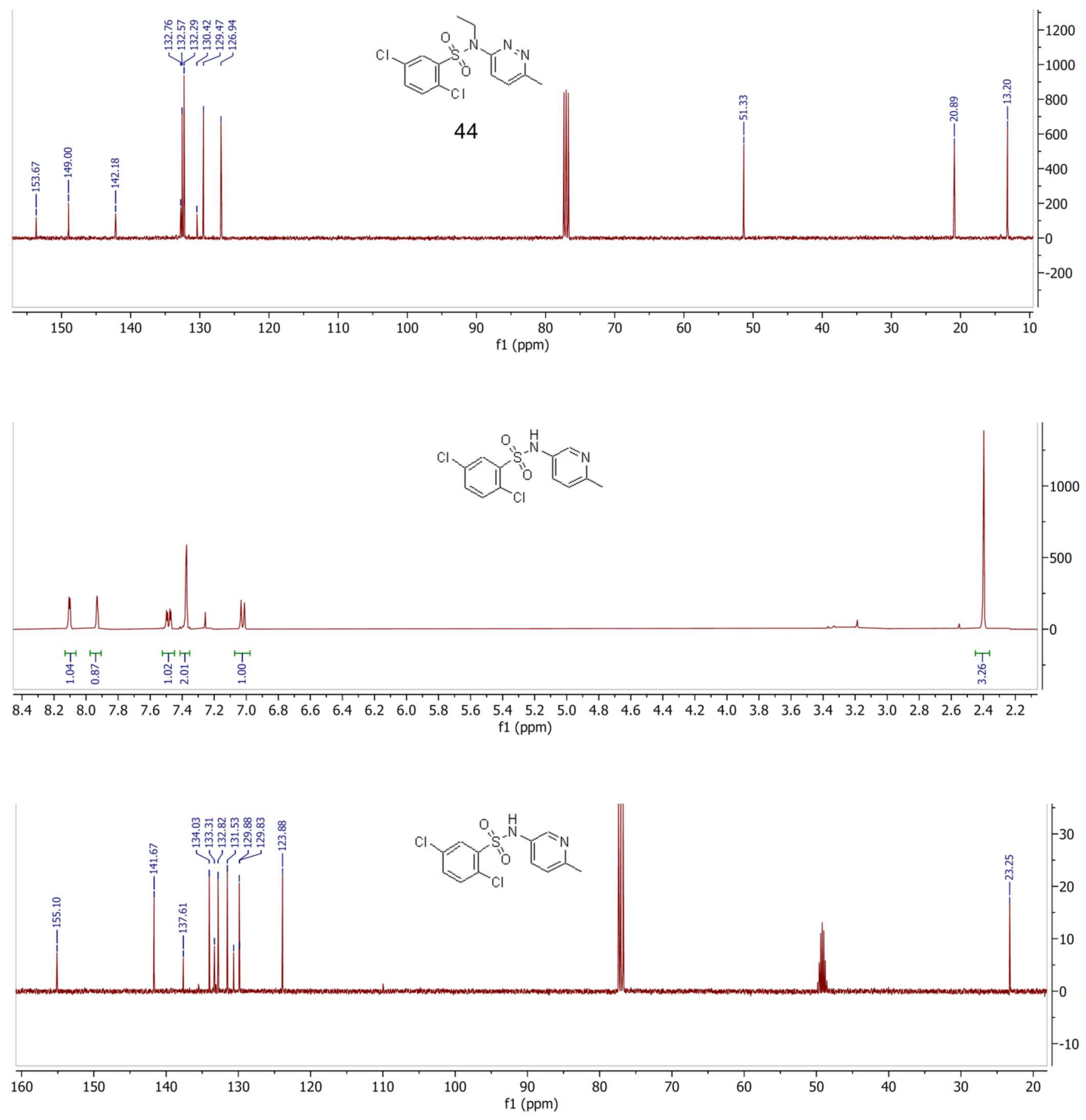

S47 

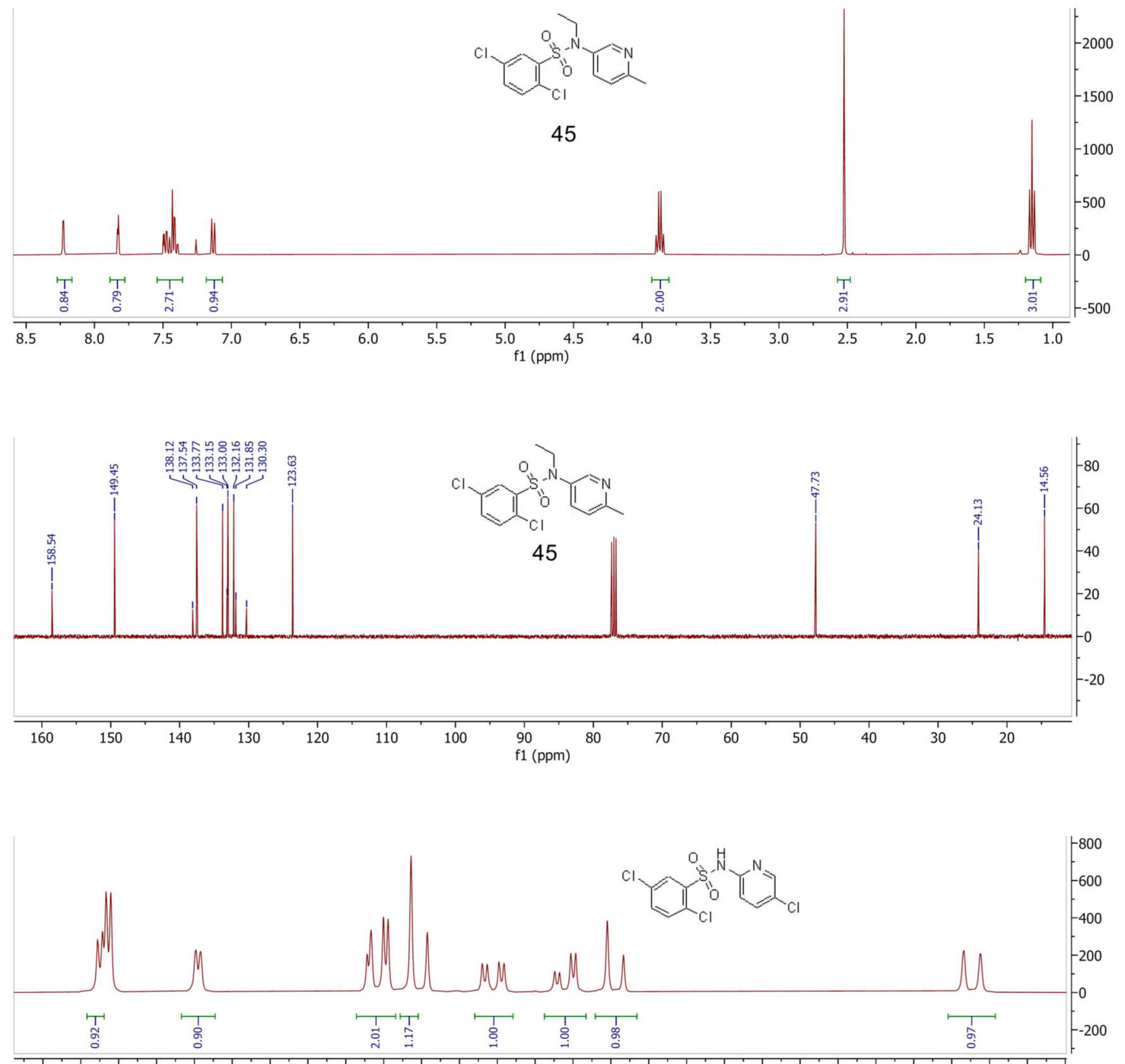

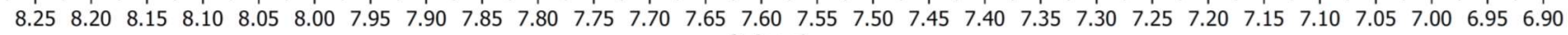
$\mathrm{f1}(\mathrm{ppm})$ 

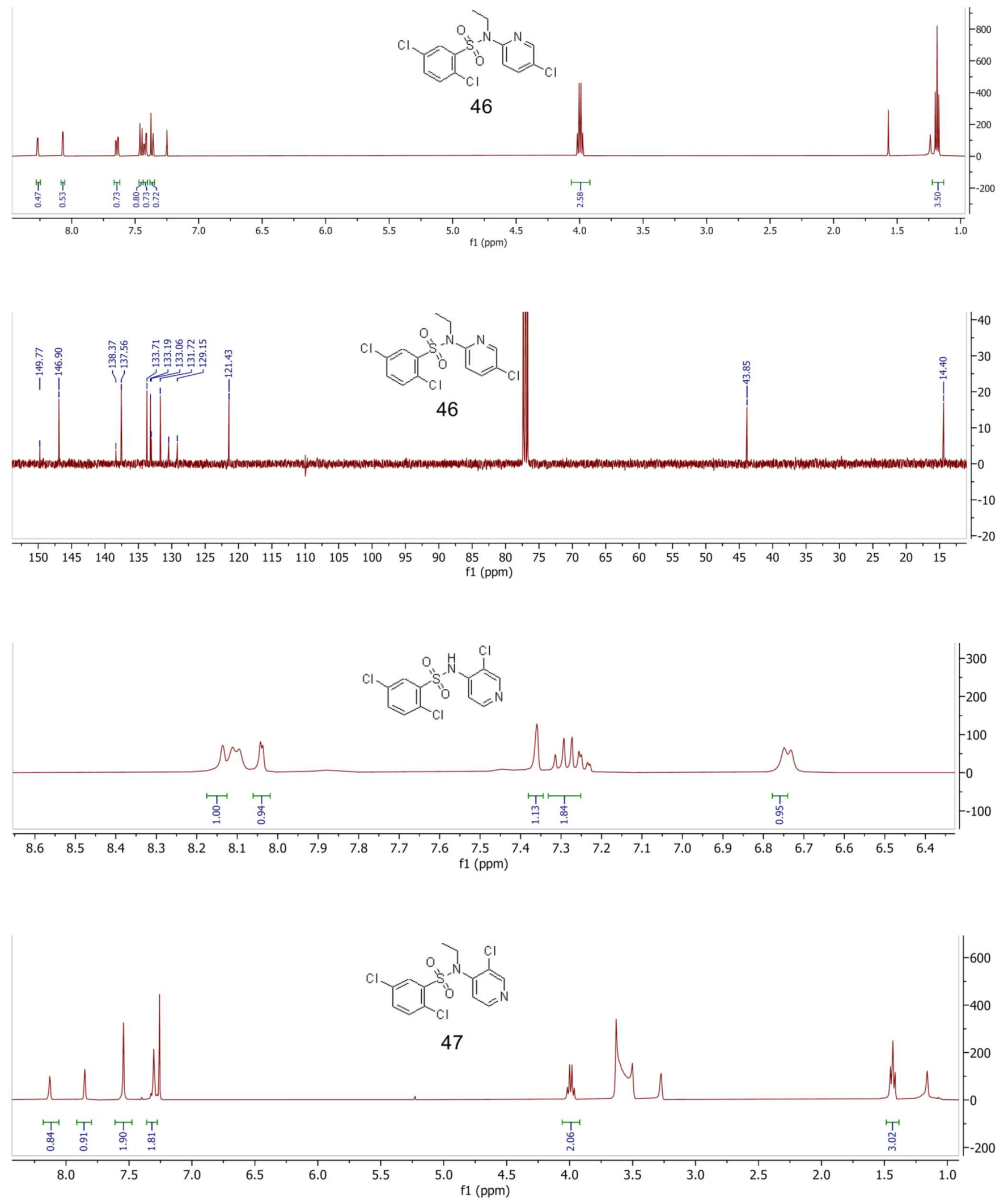

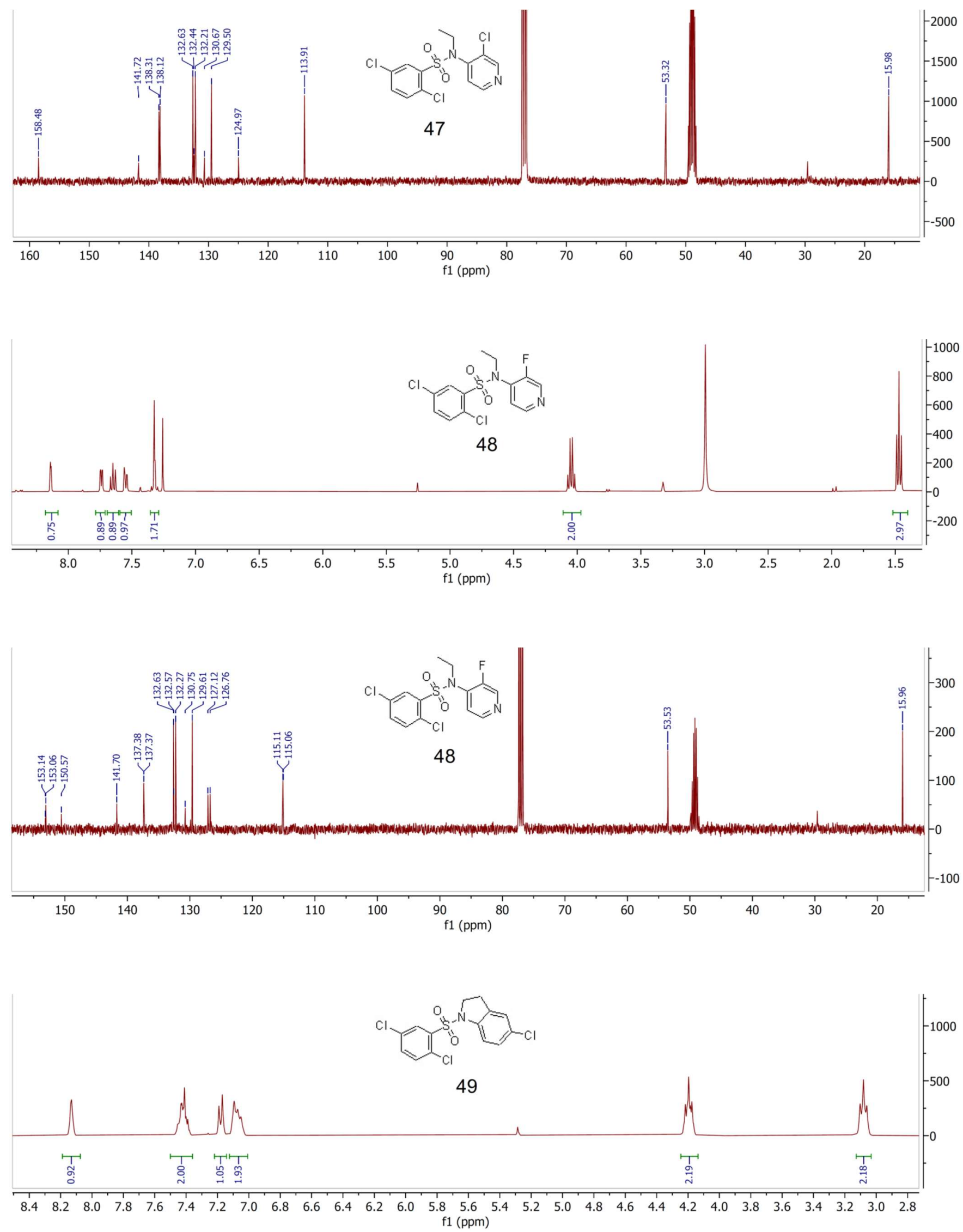

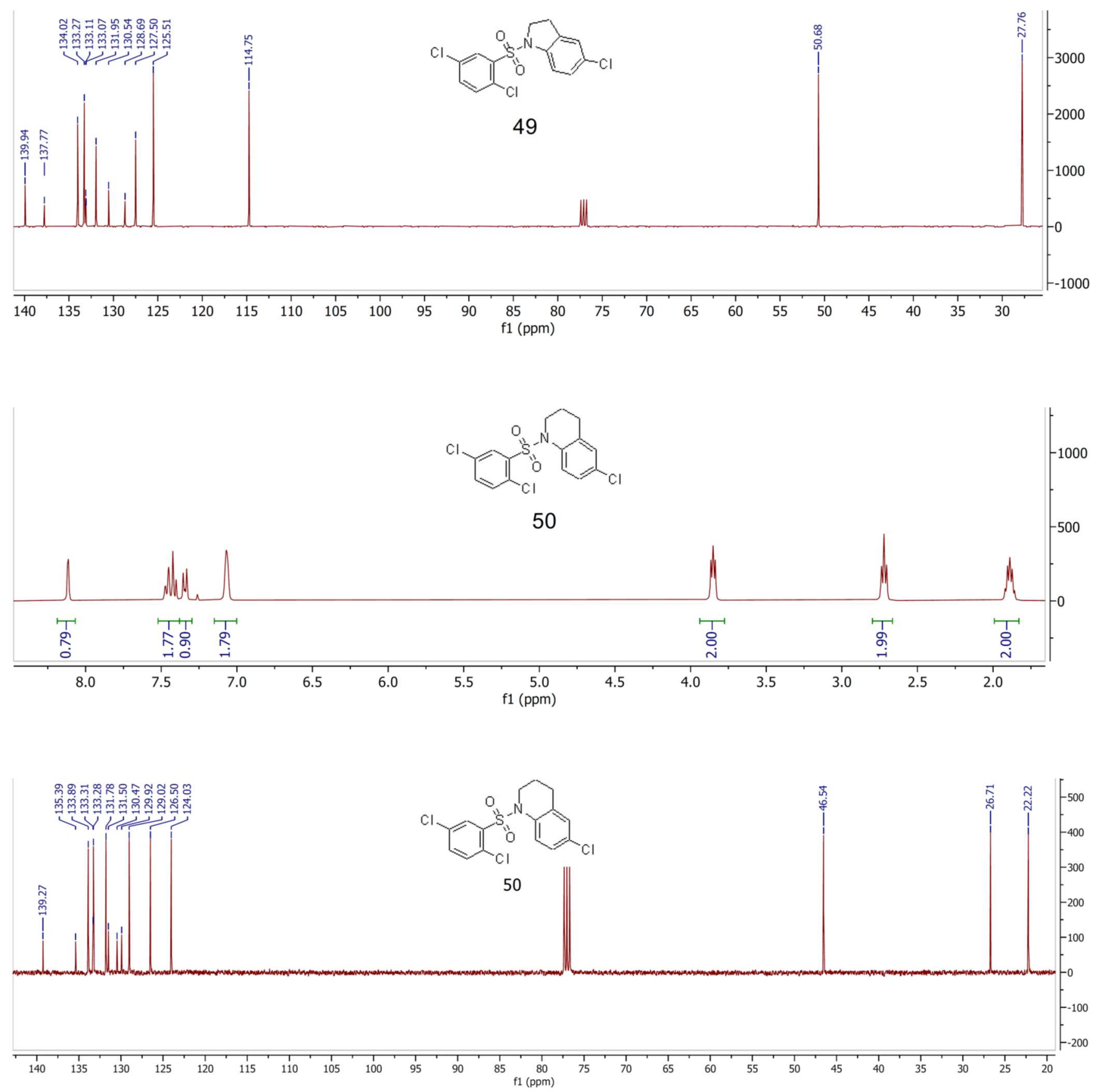

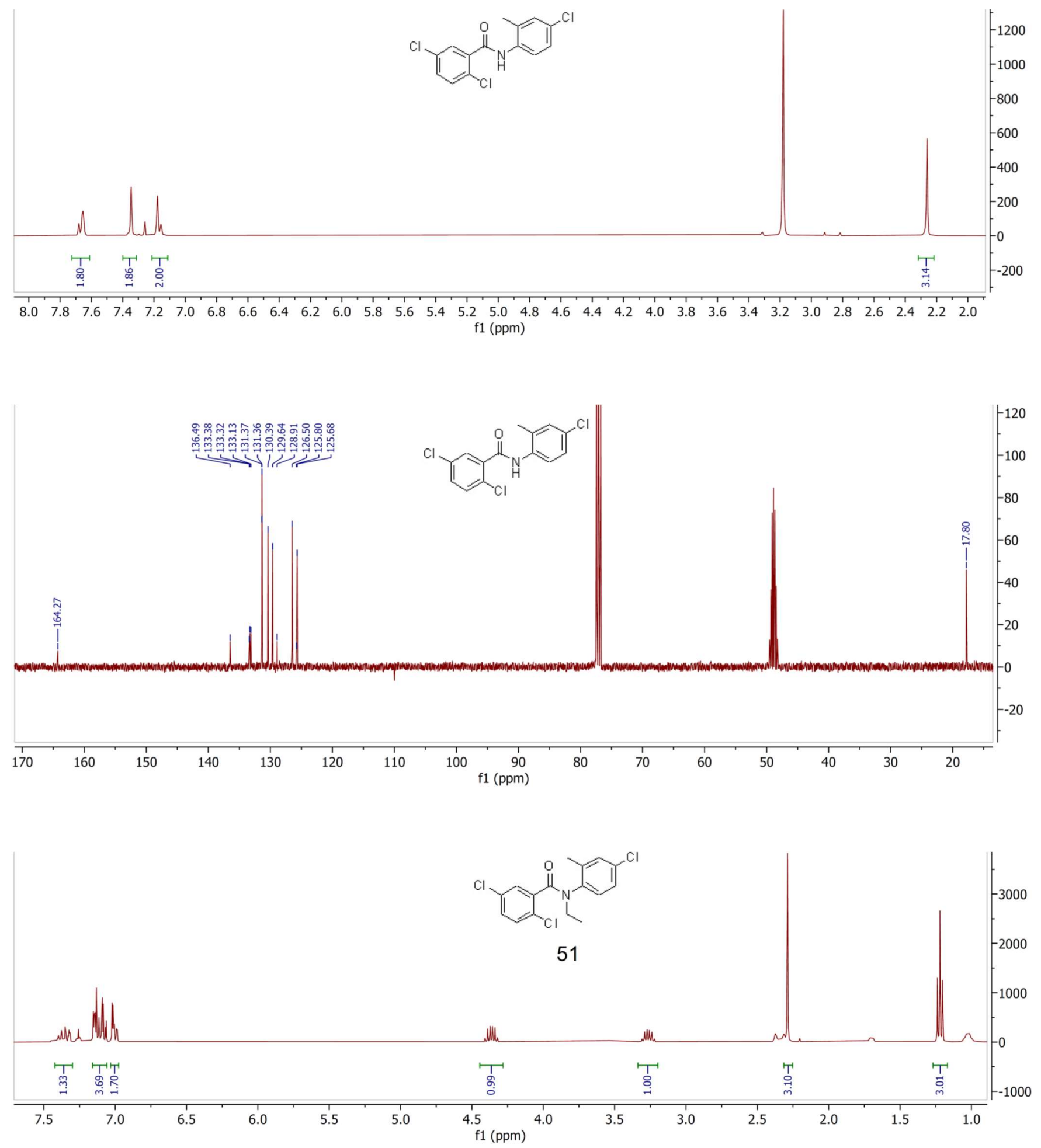

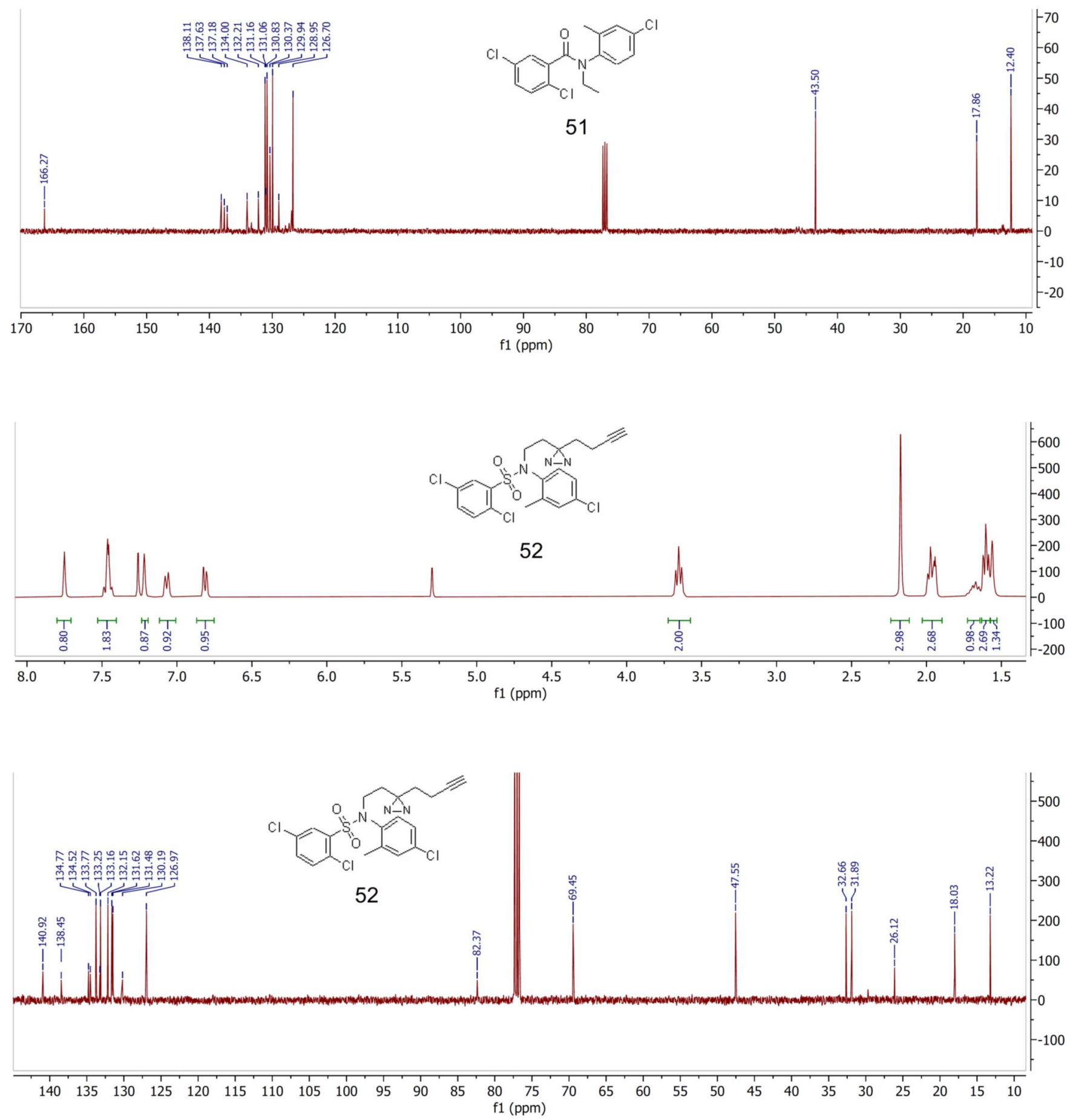



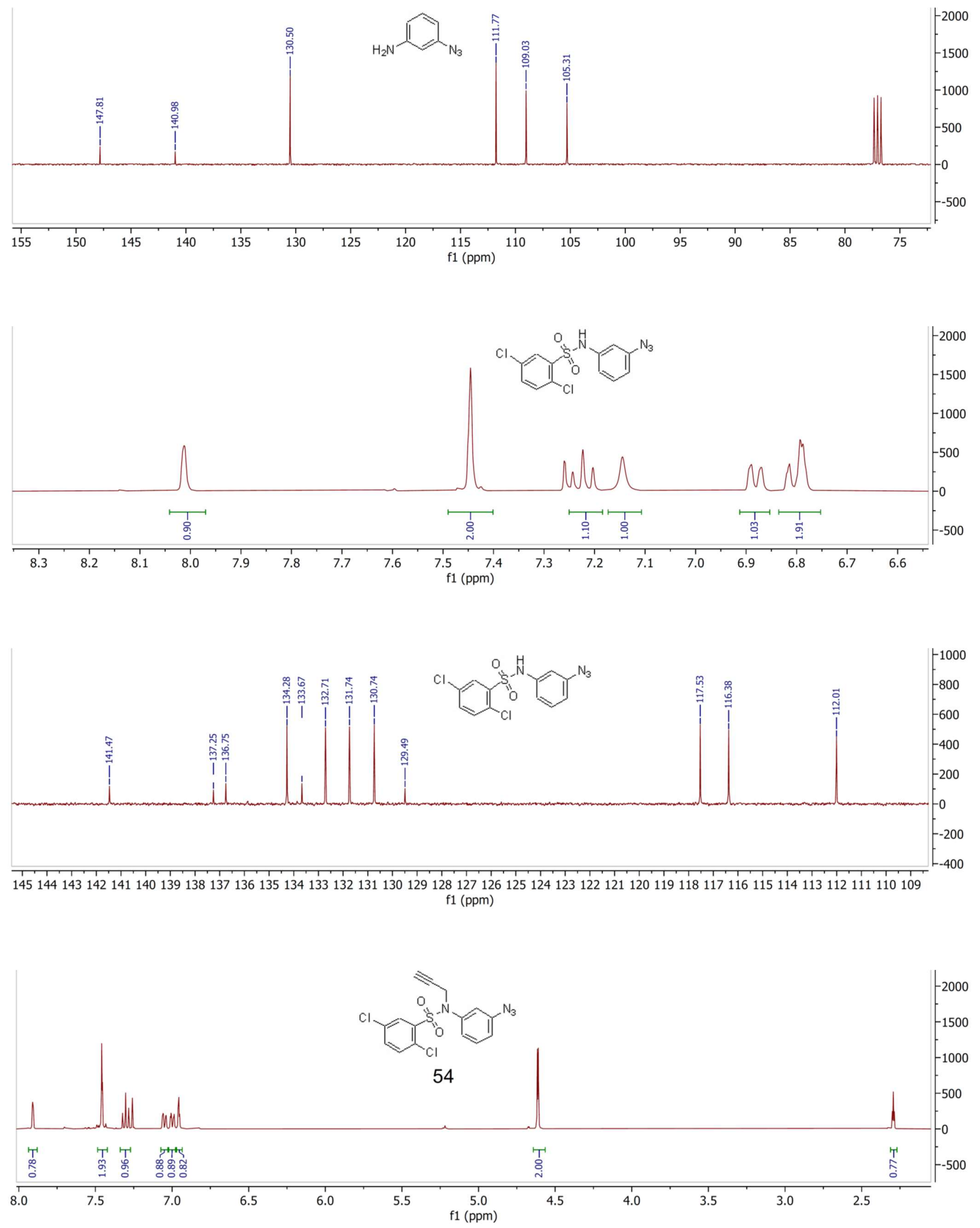


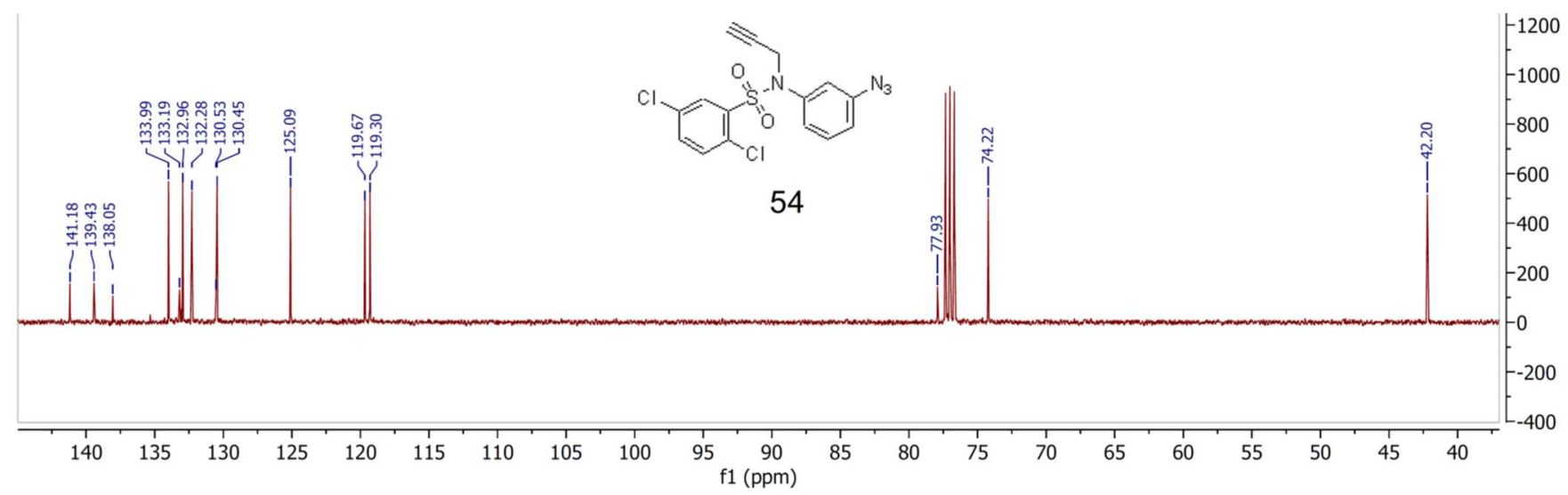

